QL

691

S64012

1917

BIRDS

(1)

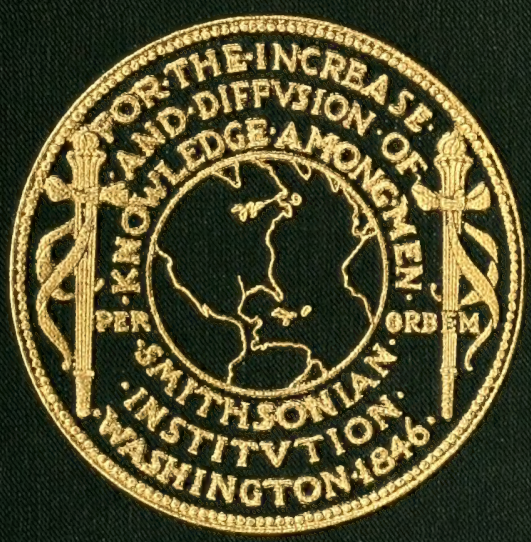











\title{
THE BIRDS OF THE ANAMBA ISLANDS
}

\author{
BY \\ HARRY C. OBERHOLSER \\ Of the Biological Survey, United States Department of Agriculture
}

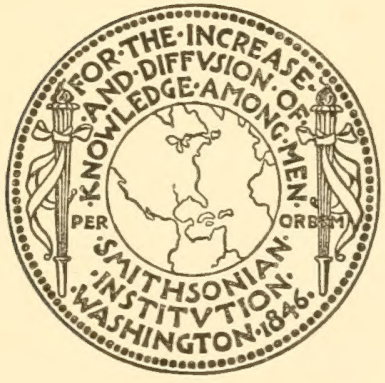

WASHINGTON

GOVERNMENT PRINTING OFFICE 
BULLETIN OF THE UNITED STATES NATIONAL MUSEUM. ISSUED JUNE 30, 1917. 


\section{ADVERTISEMENT.}

The scientific publications of the United States National Museum consist of two scries, the Proccedings and the Bulletins.

The Procedings, the first volume of which was issued in 1878, are intended primarily as a medium for the publication of original, and usually brief, papers based on the collections of the National Museum, presenting newly acquired facts in zoologr, geology, and anthropology, including descriptions of new forms of animals, and revisions of limiter groups. One or two volumes are issued annually and distributed to libraries and scientific organizations. A limited number of copies of each paper, in pamphlet form, is distributed to specialists and others interested in the different subjects as soon as printed. The date of publication is printed on each paper, and these dates are also recorded in the tables of contents of the volumes.

The Bulletins, the first of which was issued in 1875, consist of a series of scparate publications comprising chiefly monographs of large zoological groups and other general systematic treatises (oceasionally in several volumes), faunal works, reports of expeditions, and catalogues of type-specimens, special collections, etc. The majority of the volumes are octavos, but a quarto size has been adopted in a few instances in which large plates were regarded as indispensable.

Since 1902 a series of octavo volumes containing papers relating to the botanical collections of the Muscum, and known as the Contributions from the National Herbarium, has been published as bulletins.

The present work forms No. 98 of the Bulletin series.

Richard RatiBden, Assistant Secretary, Smithsonian institution, In charge of the United States National Museum.

Washington, D. C., Jnne 12, 1917. 



\section{TABLE OF CONTENTS.}

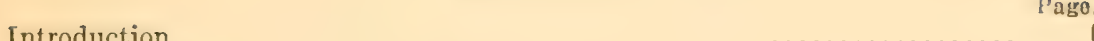

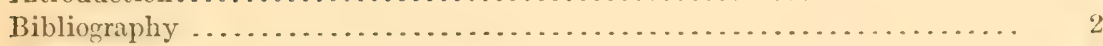

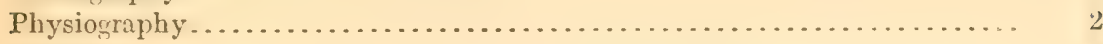

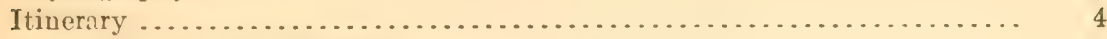

Birds of the Anamba Islands..................................... 4

Check-list of the Birds of the Anamba Islands..................... 4

Distribution of Birds, by islands. ...............................

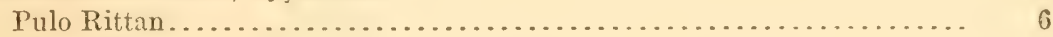

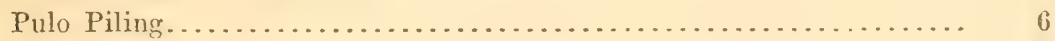

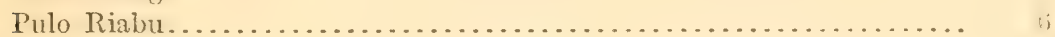

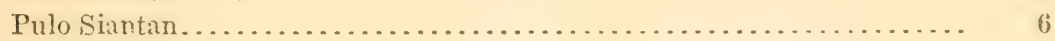

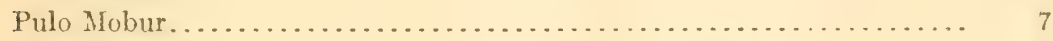

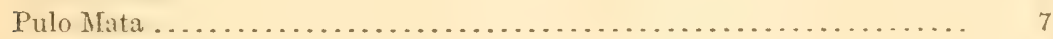

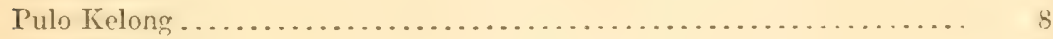

Pulo Manguan ............................................ 8

Pulo Telaga............................................. 8

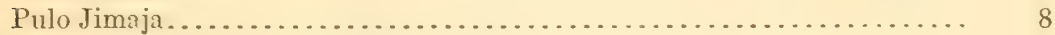

Faunal Relationships of the Anamba Islands.......................

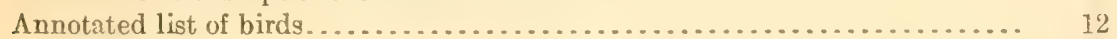

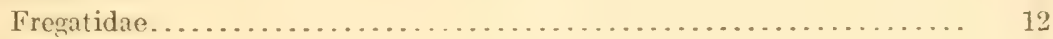

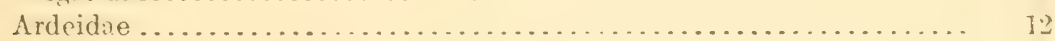

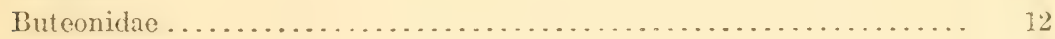

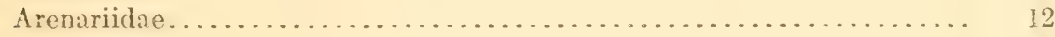

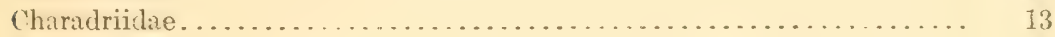

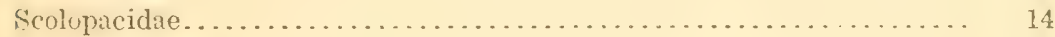

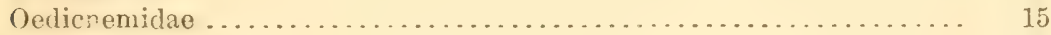

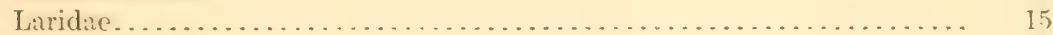

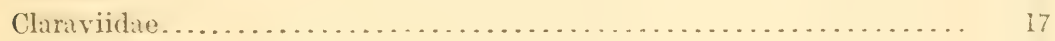

Treronidae. . . . . . . . . . . . .

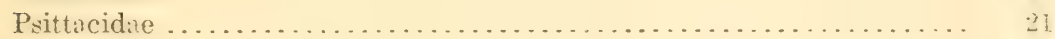

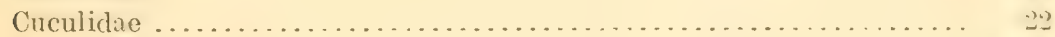

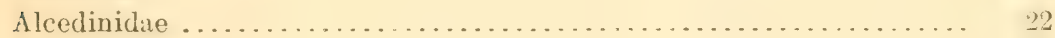

Micropodidio . . . . . . . . . . . . . . . . . .

Hemiprocnidae . . . . . . . . . . . . . . . . . . . . . . . . . .

Hirundinid:e . . . . . . . . . . . . . . . . .

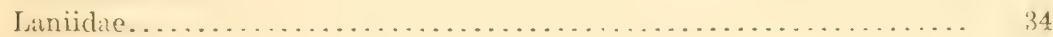

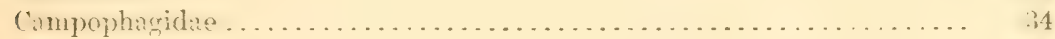

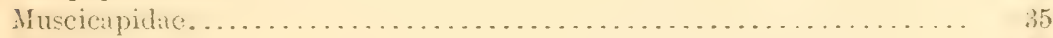

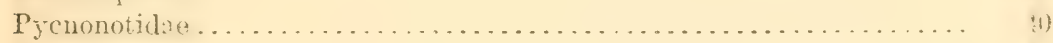

Timaliidae...........................................

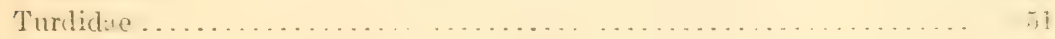

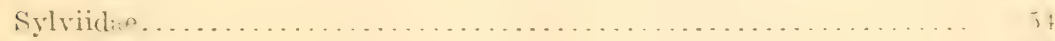

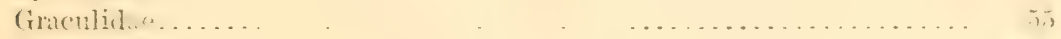

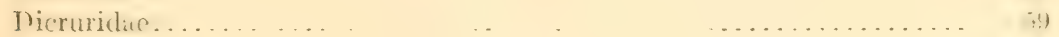

Motacillidne ......................................

Nectarinititue . . . . . . . . . . . . . . . .

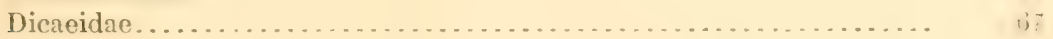

Index . . . . . . . . . . . . . . 



\title{
THE BIRDS OF THE ANAIIBA ISLANDS.
}

\author{
By Harry C. Oberholser, \\ of the Biological Survey, United States Department of Agriculture.
}

\section{INTRODUCTION.}

Dr. W. L. Abbott was the first ornithological collector to visit the Anamba Islands of the South China Sea. Accompanying him was Mr. C. Boden Kloss, who later published an account of the cruise with a nominal list of the birds of these islands. ${ }^{1}$ This trip was made in the summer and autumn of 1899. During the summer of the following year Doctor Abbott again visited these islands. As one of the results of these two excursions Doctor Abbott sent back to the United States National Museum a collection of 212 birds, representing 44 species and subspecies, which has proved to be of much interest.

The following report on the avifauna of the Anamba Islands is based entirely on Doctor Abbott's specimens, his manuscript notes, and the data published by Mr. Kloss. ${ }^{2}$ Nineteen new subspecies are here described from the Anamba Islands in addition to the two hitherto published. ${ }^{3}$ Two others-one from the Seychelles, the other from the Andaman Islands - are also named incidentally in the following pages. ${ }^{4}$

In the preparation of this contribution the writer has enjoyed the facilities of the United States National Museum, and the cordial cooperation and assistance of the assistant curator of the Division of Birds, Dr. Charles W. Richmond. The writer is also personally indebted to Doctor Abbott for geographical and other information concerning the Anamba Islands.

All measurements are in millimeters, and have been taken as explained in the writer's recent paper on Butorides rirescens. ${ }^{5}$ The names of color's employed in the deseriptions are based, except where otlenwise stated, on Mr. R. Ridgway's recently published Color

1 Journ. Straits Branch Roy. Asiatic Soc., No. 41, January, 1004, pp. 53-80.

2 Idem, pp. 68-80.

${ }^{3}$ Hypothymis azurea opisthocyanea Oberholser, Proc. U. S. Nat. MIus., vol. 39, Feb. 25, 1911, p. 602; and Collocalia fuciphaga amcchana Oberholser, Proc. U. S. Nat. Mus., vo]. 12, Mar. 6, 1912, p. 13.

4 See pp. 16 and 24.

s l'roc. U.S. Nat. Mus., vol. 42, 1912, p. 533.

$70536^{\circ}-$ Bull. 98-17-1 
Standards and Nomenclature. ${ }^{1}$ All species not represented in the collection by specimens, but included solely on the authority of Doctor Abbott or Mr. Kloss are prefixed with an asterisk.

\section{BIBLIOGRAPHY.}

The only published notes on the birds of the Anamba Islands occur in the following papers:

Kuoss, C. Boden.--Notes on a Cruise in the Southern China Sea. Journal of the Straits Branch of the Royal Asiatic Society, No. 41, January, 1904, pages 53-80.

Oberioloser, Harry C.-A Monograph of the Genus Collocalia. Proceedings of the Academy of Natural Sciences of Philadelphia, April (July 26), 1906, pages 177-212.

Oberholser, Harry C.-A Monograph of the Flycatcher Genera Hypothymis and Cyanonympha. Proceedings of the United States National Museum, vol. 39, February 25, 1911, pages 585-615.

Oberiolser, Harry C.-A Revision of the Forms of the Edible Nest Swiftlet, Collocalia fuciphaga (Thunberg). Proceedings of the United States National Museum, vol. 42, March 6, 1912, pages 11-20.

Oberholser, Harry C.-A Symopsis of the Races of the Crested Tern, Thalasseus bergii (Lichtenstein). Proceedings of the United States National Museum, vol. 49, Decemler 23, 1915, pages 515-526, pl. 66 .

\section{PHYSIOGRAPHY.}

The Anamba Islands are situated in the southern portion of the South China Sca, between the Natuma Islands and the Malay Peninsula. The center of the group lies approximately in latitude $3^{\circ}$ north and in longitude $106^{\circ}$ east; and in an air line is about 140 miles from the nearest point of the Malay Peninsula, 225 miles from Borneo, 240 miles from Sumatra, 610 miles from Java, and 400 miles from the nearest part of the mainlanel of Cochin China.

There are about 20 principal islands, and possibly 200 more islets and rocks, spread over a geographical area some 55 miles east and west and 65 miles north and south. All fall roughly into three groups: A southern group, which inclules Pulo Ropon, Baua, Rittan, Riahu, Piling, and White Rock; a northern group, which includes Pulo Siantan, Mata, Mobur, Kelong, Minjalin, Panjang, and Manguan: and a western group, made up of Pulo Jimaja, Telaga, Little Telaga, and Pulo Domar, with, as in the other groups, many islets and rocks.

Nearly all the islands are high and rocky; formed chiefly of hard rocks and laterite, and with a fringe of coral reefs about their bases. There are also many coral reefs between the islands; while the

1 Ridgway, Color Standards and Color Nomenclature, 1912 (Jan. 16, 1913). 


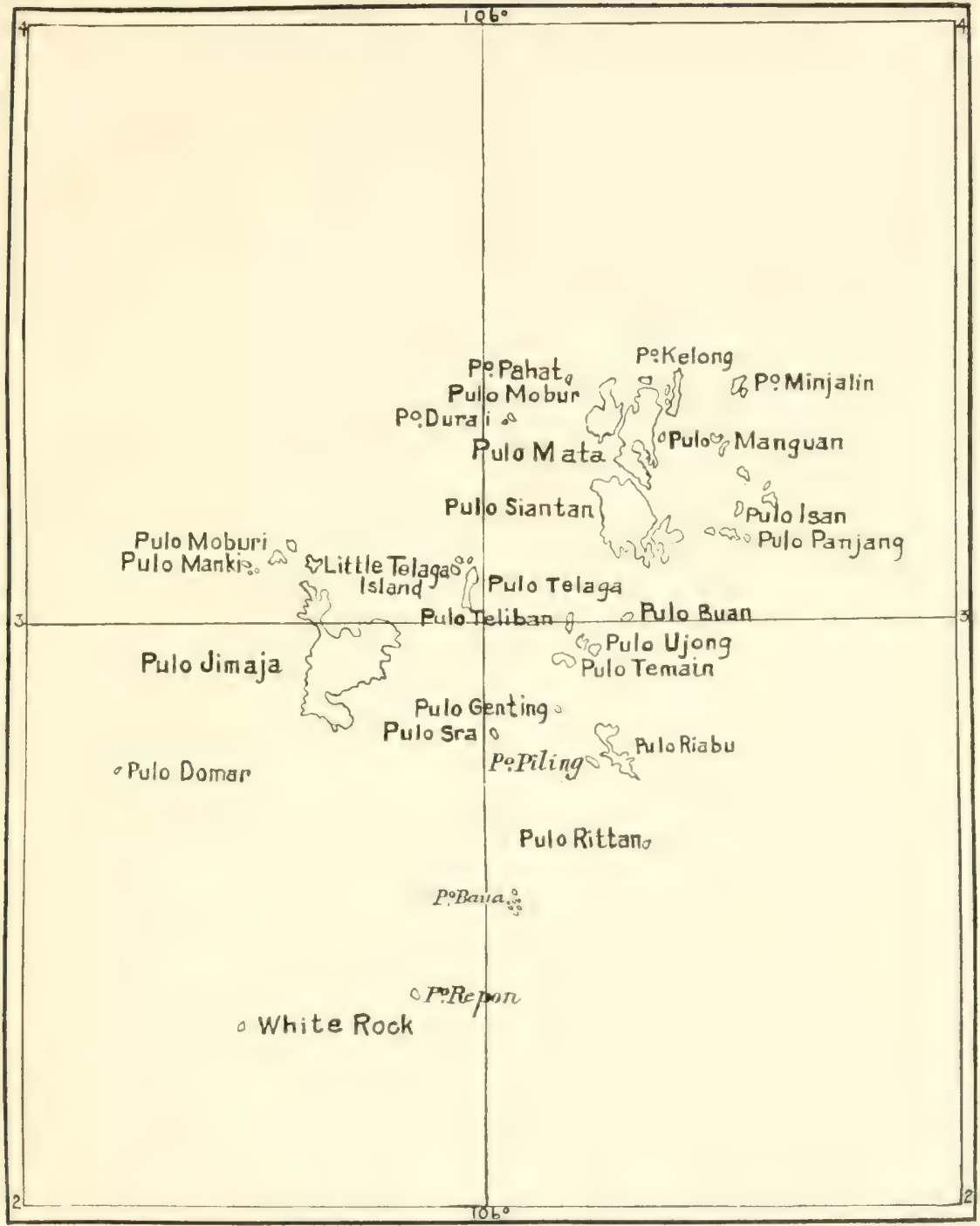

SKETCH MAP OF THE ANAMBA ISLANDS. 

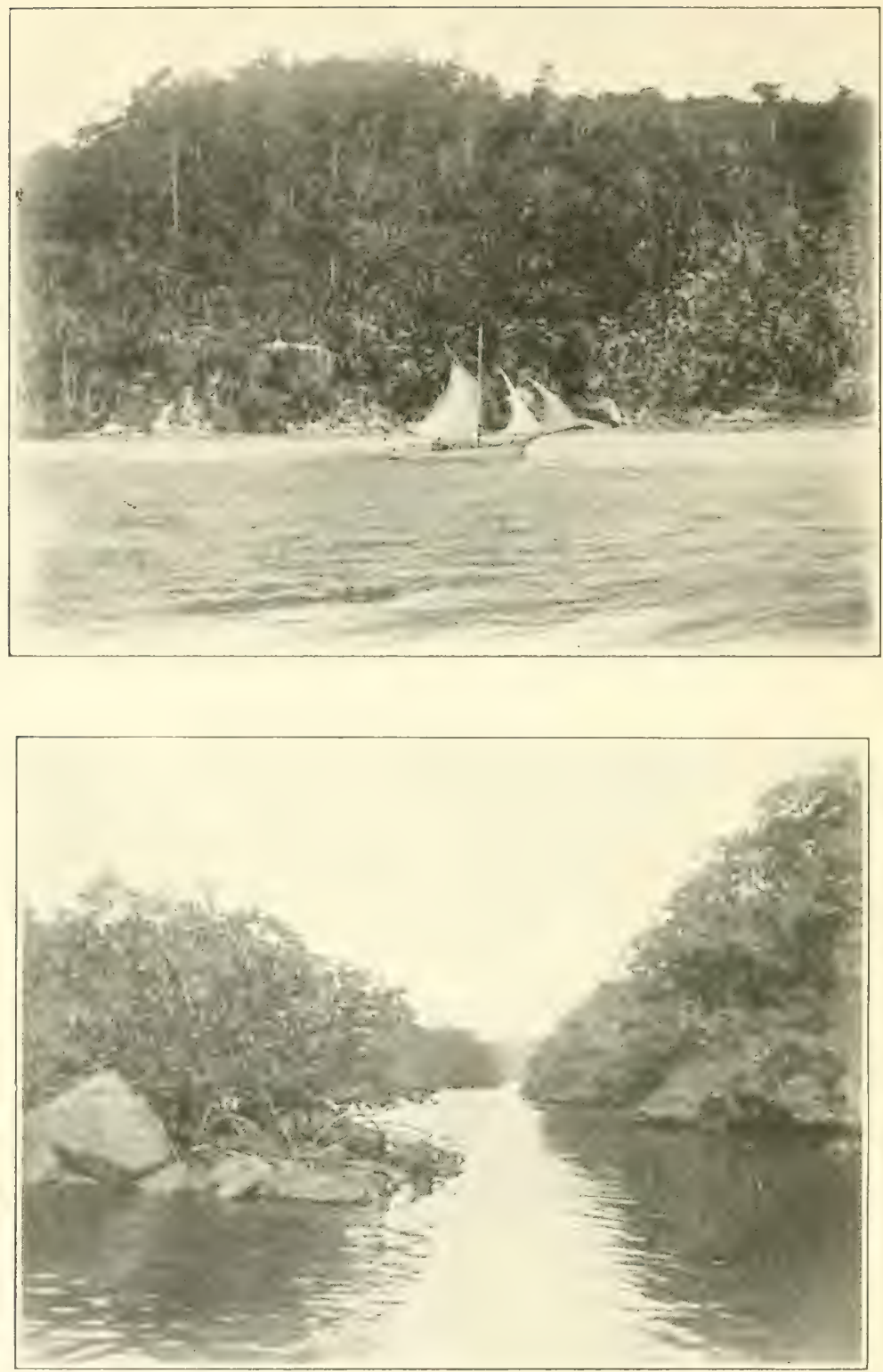

UpPer: CoAstal Forest on PULO Jimaja, ANAMBa IsLands, the HOME of HORIZILLAS MAGNIROSTRIS AND AETHOPYGA SIPÁRAJA OCHROPYRRHA.

Lower: Mangroves ALONG THE COAST OF PULO SiANTAN, ANAMBa ISLANDS. 
islands of the main, or northern, group -Siantan, Mata, Mobur, ete- -are virtually comnected by them. The islancis have many coastal indentations, and the numerous resulting bays and rhannels afford good anchorages. The soil of at lealst the larger istands is fairly fertile and supports nearly everywere a good foresi growth, ${ }^{1}$ except where cleared for cultivation or the planting of coconut treess. These clearings are mumerous along the coast of rome of the larger islands, while from a few of the smaller islanels the forest has entirely disappeared in this way.

Wild mammals are not numerous, and comsist chiefiy of various species of rats, squirrels, monkeys, tree shiews (Tuprik), and hats.

The climate of these islands, owing to frecuent heary rains and fresh breezes, is much cooler than that of Siam.

The population of the Anamba Istames is probably not orer 3,000 or 4.000, male up mostly of Malays, with a fow Chinese traters. The principal village is Terempar, on a little bay on the norihwestern coast of Pulo Siantan. It is inhabited chiefly by Chinese, who have here many shops.

The island of Jimaja, or Pulo ${ }^{2}$ Jinaja, the largest of the group, is about 14 miles in length north and south, about 9 miles wide, and has an area of approxinately $t \bar{t}$ square miles. The surfare is uneven, and there are many peaks orer 700 feet high, the groatsest. elevation being 1,530 feet. 'The coast line is rery irregular, and there are consequently numerous hays. In places along the coant there are swampy areas of limited extent grown up to mangroves. There are a number of streams on the island, also a fow low waterfalls and pools, the latter merely rocky basins in the stream bxils.

Pulo Siantan, in the eastern part of the Anamba Arehipulago, is the second largest island, with an area of about 31 square miles. It is rough and hilly, and rises at one point to an altitu? of 1,855 feet. There are some small streams on this istand, and on the northcastern coast a waterfall about 400 foet high. This island is heavily forested, and has also patehes of mangrores in places along its coatit."

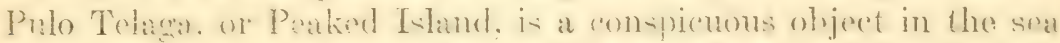
bewen the nothern and westan aponps, and is surromuled by a number of smaller islands. It is a narrow wooded ridge, about 5

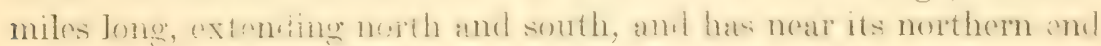
a picturesque poak 1,740 feet in height.

Pulo Mat:t and Pule Sfohur, which lie a short distance north of Pul, Simntan, ate among the larger islands. and do not differ in characteristics from those already described.

Pulo Keloner montheast of P'ulo Mata, is a natrow island some 5 miles in length and in mile or les in whith cats and wort. with its ridge rising to a height of 600 or 700 feet. 


\section{ITINERARY.}

Doctor Abbott visited the following islands of the Anamba group on the dates given after each:

Puto Rittan.-May 21, 1900.

Pulo Piling.-August 17, 1899.

Pulo Riabu.-August 18, 1899, and August 22-23, 1900.

Pulo Siantan.-Terempa, August 19-24, 1899; September 7-13, 1899; Telok Ayer Bini, September 5-6, 1899.

Pulo Mobur.-August 24 to September 1, 1899.

Pulo Mata.-August 24 to September 1, 1899.

Pulo Kelong.-September 1, 1899.

Puto Manguan.-September 1-2, 1899.

Pulo Telaga. - September 14-15, 1899.

Puto Jimaja.-September 17-28, 1899.

\section{BIRDS OF THE ANAMBA ISLANDS.}

The total number of birds, species and subspecies, at present known from the Anamba Islands is 56, of which Doctor Abbott reported 45 and $\mathrm{Mr}$. C. B. Kloss the remaining $11 .{ }^{1}$ This is, of course, considering the area involved, not a large number, and doubtless will bo greatly increased by future explorations. The Anamba group, however, seems not to be so rich in bird life as are the Natuna Islands, which lie much nearer Borneo. The complexion of its bird fauna may be seen from the subjoined

CHECK-LIST OF THE BIRDS OF THE ANAMBA ISLANDS.

1. Fregata minor minor (Gmelin).

2. Butorides javanicus javanicus (Horsfield).

3. Demiegretta sacra sacra (Gmelin).

4. Cuncuma leucogastris (Gmelin).

5. Arenaria interpres oahuensis (Bloxham).

6. Pluvialis dominica fulva (Gmelin).

7. Pagoa leschenaultii (Lesson).

8. Cirrepidesmus atrifrons (Wagler).

9. Totanus totanus eurhimus Oberholser.

10. Pisobia ruficollis (Pallas).

11. Actitis hypoleuca (Linnaeus).

12. Orthorhamphus magnirostris (Vieillot).

13. Thalasseus bergii pelecanoides (King).

14. Sterna melanauchen melanauchen Temminck.

15. Anous stolidus pileatus (Scopoli).

16. Caloenas nicobarica (Linnaeus).

17. Chalcophaps indica indica (Linnaeus).

18. Myristicivora bicolor (Scopoli).

19. Muscadivores aeneus polius Oberholser. ${ }^{2}$

20. Dendrophassa vernans adina Oberholser. ${ }^{2}$

21. Loriculus galgulus (Linnaeus).

1 Joturn. Straits Branch Roy. Asiatic Soc., No. 41, January, 1904, p. 79.

2 Now subspecies; described beyond. 
22. Conurus longicaudus (Boddaert).

23. Urococcyx erythrognathus (Hartlaub).

24. Sauropatis chloris cyanescens Oberholser.

25. Alcedo ispida bengalensis Gmelin.

26. Ceyx rufidorsus rufidorsus Strickland.

27. Mficropus subfurcatus (Blyth).

28. Collocalia lowi (Sharpe.)

29. Collocalia vestita amechana Oberholser.

30. Hemiprocne longipennis harterti Stresemann.

31. Hemiprocne comata comata (Temminck).

32. Hirundo rustica gutturalis Scopoli.

33. Hypurolepis javanica abbotti Oberholser. ${ }^{1}$

34. Lanius cristatus Linnaeus.

35. Artamides sumatrensis calopolius Oberholser.'

36. Cyornis banyumas lampra Oberholser. ${ }^{1}$

37. Xanthopygia zanthopygia (Hay).

38. Hypothymis azurea opisthocyanea Oberholser.

39. Aegithina viridissima thapsina Oberholser. ${ }^{1}$

40. Pycnonotus plumosus chiroplethis Oberholser. ${ }^{1}$

41. Pycnonotus simplex halizonus Oberholser. ${ }^{1}$

42. Pycnonotus brunneus zapolius Oherholser. ${ }^{1}$

43. Horizillas magnirostris (Moore).

44. Anuropsis malaccensis malaccensis (Hartlaub).

45. Mixornis pileata zophera Oberholser. ${ }^{1}$

46. Kittacincla malabarica ochroptila Oberholser. ${ }^{1}$

47. Kittacincla malabarica heterogyna Oberholser. ${ }^{1}$

48. Orthotomus atrogularis Temminck.

49. Gracula javana prasiocara Oberholser. ${ }^{1}$

50. Lamprocorax panayensis hetcrochlorus Oberholser. ${ }^{1}$

51. Dissemurus paradiseus microlophus Oberholser."

52. Motacilla boarula melanope Pallas.

53. Anthreptes malacensis anambae Oberholser. ${ }^{1}$

54. Cinnyris brasiliana eumecis Oberholser. ${ }^{1}$

55. Acthopyga siparaja ochropyrrha Oberholser. ${ }^{1}$

56. Dicaeum trigonostigmum hypochloum Oberholser. ${ }^{1}$

\section{DISTRIBUTION OF BIRDS BY ISLANDS.}

So far as known. thare is only a single speceins, Fittacincla mala-

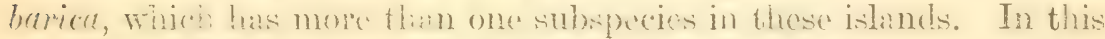

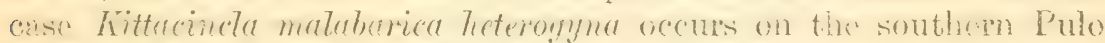

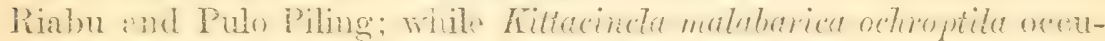

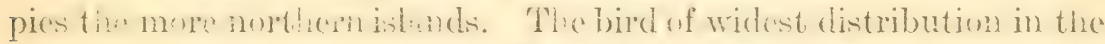

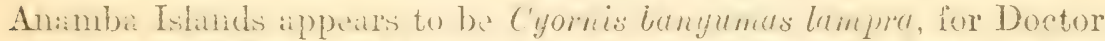
Abbott fonnd it on 9 of tine 10 islands that he risited. Next to this, Dissenurus paralisens microlophus, Anthreptes malacosis cinambae, and dethopyga siparaja octerop?prha wore cach found on \& islands; iluscudirores aemens potius on 7 ; Dendrophassu ermans adina on 6; Hypurolepis jatanica abbotti, Mypothymis azupu opisthocyanca, and Gracula jacena masiocura on 5 islands; and the following on 4 : Cuncuma leucogustris, Ifyristicivora bicolor, Alcedo ispida bengalcmis, 
Mixomis pileata zophera, Kittncincla malabarica ochroptila, Oithotomus atrogularis, and Lamprocorax panayensis heterochlorus.

Lists of the birds found by Doctor Abbott on the different islinds are given below.

PULO RITTAN.

Myristicivora bicolor.

Cyornis banyumas lampra.

Anthreptes malacensis anambae.

Aethopyga siparaja ochropyrrha.

Myristicivora bicolor.

Cyornis banyumas lampra.

Hypothymis azurea opisthocyanea.

Kittacincla malabarica heterogyna.

Gracula javana prasiocara.

Dissemurus paradiseus microlophus.

PULO RIABU.

Cuncuma leucogastris.

Myristicivora bicolor.

Muscadivores aeneus potius.

Alcedo ispida bengalensis.

Collocatia lowi.

Hypothymis azurea opisthocyanea.

Pycnonotus plumosus chiroplethis.

Mixornis pileata zophera.

Kittacincla malabarica heterogyna.

Gracula javana prasiocara.

Dissemurus paradiseus microlophus.

PULO SIANTAN.

Cuncuma leucogastris.

Actitis hypoleuca.

Muscadivores aeneus polius.

Dendrophassa vernans adina.

Urococeyx erythrognathus.

Sauropatis chloris cyanescens.

Alcedo ispila bengalensis.

Hypurolepis javanica abbotti.

Cyornis banyumas lampra.

Xanthopygia zanthopygia.

Hypothymis azurea opisthocyanea.

Aegitlina viridissima thapsina.

Pycnonotus plumosus chiroplethis.

Pycnonotus simplex hatizonus.

Pycnonotus brunneus zapotius. 
Horizillas magnirostris.

Anuropsis malaccensis malaccensis.

Mixornis pileata zopherc.

Kittacincla malabarica ochroptila.

Orthotomus atrogularis.

Gracula javana prasiocara.

Lamprocorax panayensis heterochlorus.

Dissemurus paradiseus microlophus.

Anthreptes malacensis anambae.

Cinnyris brasitiana eumecis.

Aethopyga siparaja ochropyrrha.

Dicaeum trigonostigmum hypochloum.

PULO MOBUR.

Chalcophaps indica indica.

Myristicivora bicolor.

Muscadivores aeneus potius.

Dendrophassa vernans adina.

Sauropatis chloris cyanescens.

Cyornis banyumas lampra.

Pycnonotus plumosus chiroplethis.

Orthotomus atrogularis.

Gracula javana prasiocara.

Lamprocorax panayensis heterochlorus.

Dissemurus paradiseus microlophus.

Anthreptes malacensis anambae.

Aethopyga siparaja ochropyrrha.

Dicaeum trigonostigmum hypochloum.

PULO MATA.

Arenaria interpres oahuensis.

Cirrepidesmus atrifrons.

Pisobia ruficollis.

Thatasseus bergii pelecanoides.

Sterna melanauchen melanauchen.

Muscadivores aeneus polius.

Dendrophassa vernans adina.

Sauropatis chloris cyanescens.

Hypurolepis javanica abbotti.

Artamides sumatrensis calopolius.

Cyornis banyumas lampra.

Horizillas magnirostris.

Orthotomus atrogularis.

Lamprocorax panayensis heterochtorus.

Anthreptes malacensis anambae.

Aethopyga siparaja ochropyrha. 
PULO KELONG.

Pagoa Teschenaultii.

Cirrepidesmus atrifrons.

Thatasseus bergii pelecanoides.

Sterna melanauchen melanauchen.

Cyornis banyumas lampra.

Kittacincla malabarica ochroptila.

Dissemurus paradiseus microlophus.

Anthreptes malacensis anambae.

Aethopyga siparaja ochropyrrha.

PULO MANGUAN.

Muscadivores aeneus potius.

Alcedo ispida bengalensis.

Hypurolepis javanica abbotti.

Cyornis banyumas lampra.

Hypothymis azurea opisthocyanea.

Kittacincla malabarica ochroptila.

Gracula javana prasiocara.

Dissemurus paradiseus microlophus.

Motacilla boarula melanope.

Anthreptes malacensis anambae.

Cinnyris brasitiana eumecis.

Aethopyga siparaja ochropyrrha.

PULO TELAGA.

Cuncuma leucogastris.

Actitis hypoleuca.

Muscadivores aeneus polius.

Dendrophassa vernans adina.

Hypurolepis javanica abbotti.

Cyornis banyumas lampra.

Hypothymis azurea opisthocyanea.

Mixornis pileata zophera.

Lamprocorax panayensis heterochlorus.

Dissemirus paradiseus microlophus.

Anthreptes malacensis anambae.

Aethopyga siparaja ochropyrrha.

Cuncuma leucogastris.

PULO JIMAJA.

Totanus totanus eurhinus.

Muscadivores aeneus polius.

Dendrophassa vernans adina.

Conurus longicaudus.

Alcedo ispida bengalensis. 
Ceyx rufidorsus rufidorsus.

Collocalia vestita amechana.

Hemiprocne longipennis tarterti.

Hirundo rustica gutturalis.

Hypurolepis javanica abbotti.

Cyornis banyumas lampra.

Hypothymis azurea opisthocyanea.

Pycnonotus simplex hatizonus.

Horizillas magnirostris.

Anuropsis malaccensis malaccensis.

Mixornis pileata zophera.

Kittacincla malabarica ochroptila.

Orthotomus atrogularis.

Dissemurus paradiseus microlophus.

Anthreptes malacensis anambae.

Cinnyris brasitiana eumecis.

Aethopyga siparaja ochropyrrha.

FAUNAL RELATIONSHIPS OF THE ANAMBA ISLANDS.

The southern end of the South China Soa is hemmed in on the east by Borneo, and on the west by Sumatra and the Malay Peninsula. To the south are the southeastern end of Sumatra, and, be yond the Jara Sea, the island of Jara; while to the north the nearest land mass is the mainland of Indo-China. Seattered all through the southern pertion of the Sonth rhina Sea are numerous small islands, the largest of which, Banka and Billiton, mark the transition to the Java Sea.

The arifumal rutionships of the Anamba Islands are, as would be experteci, with the small islands of the adjorent waters, and with the five large land areas ahore mentioned. A brief analysis will aid in detemining to which of the latter the Anamba Islands are most closely attinet. Of the 56 hids now linown from the Anamba groul), the folloring 11 are migrants frem the north, do not breed here, and hence are to be disregarded in faunal comparisons:

Arenaria interpres oahuensis.

Pluvialis dominica fulva.

Pagoa leschenaultii.

Cirrepidesmus atrifrons.

Totanus totanus eurhinus.

Pisobia ruficollis.

Actitis hypoleuca.

Hirundo rustica gutturalis.

Lanius cristatus.

Xanthopygia zanthopygia.

Motacilla boarula melanope. 
The remaining 45 species and subspecies may properly form the basis of our famal deductions. There are not yet sufficient data for entirely satisfactory comparison of the birds of the various islands or groups of islands in the Anamba archipelago; but so far as I can see from our present knowledge there is very little difference between the individual islands, or between the islands of the eastern and western or northern and southern parts of the group. My treatment here is, therefore, of the Anamba Islands as a faunal whole.

Fifteen species, or rather their subspecific representatives, are peculiar to the Anamba Islands, as follows:

Muscadivores aeneus potius.

Dendrophassa vernans adina.

Collocalia vestita amechana.

Artamides sumatrensis calopolius.

Cyornis banyumas lampra.

Pycnonotus plumosus chiroplethis.

Pycnonotus simplex halizonus.

Pycnonotus brunneus zapolius.

Mixornis pileata zophera.

Kittacincla malabarica heterogyna.

Gracula javana prasiocara.

Dissemurus paradiseus microlophus.

Anthreptes malacensis anambae.

Cinnyris brasitiana eumecis.

Dicaeum trigonostigmum hypochloum.

Of these, the nearest relatives of 7 are found in the Malay Peninsula; of 4 on Sumatra; of 4 on Borneo; of 2 on Java; and of 1 in IndoChina. ${ }^{1}$

Subspecies of 6 other species are, outside of the Anamba Islands, confined to some of the other small islands of the South China Sea, chiefly the Natuna Islands, the Tambelan Islands, Pulo Tioman, and Karimata Island. These subspecies are:

Hypurolepis javanica abbotti.

Hypothymis azurea opisthocyanea.

Aegithina viridissima thapsina.

Kittacincla malabarica ochroptila.

Lamprocorax panayensis heterochlorus.

Aethopyga siparaja ochropyrrha.

Of these, 6 find their nearest relatives in the Malay Peninsula, 1 on Sumatra, 1 on Borneo, 1 on Java, and none in Indo-China. ${ }^{1}$

The remaining 24 Anamba birds belong to moro or less wide ranging Asian, Indo-Malayan, East Indian, Polynesian, Australian, Old World tropical, or tropicopolitan species. Twenty-two of these

\footnotetext{
${ }^{1}$ In this, as in the following enumeration, it is necessary to explain that the nearest relative of some of the Anamba birds occurs in more than one of the five areas above mentioned.
} 
occur in the Malay Peninsula; 22 on Sumatra; 21 on Borneo, 14 on Java; and 11 in Indo-China.

It will readily be secn by examination of these facts that the Anamba Islands, in so far at least as their avifauna indicates, are most closely related to the Malay Peninsula; less so but about equally to Sumatra and Borneo; still less to Jara, and only comparatively slightly to Indo-China.

The data on the faunal relationships of Anamba birds given in the above paragraphs may be more graphically presented in the following table. In this the first column is reserved for endemic forms; in the other columns occurrence of the Anamba birds themselves is indicated by an asterisk $\left(^{*}\right)$; and of their nearest relatives by a dagger ( $($ ).

Faunal relationships of the resident birds of the Anamba Islands.

Fregala minor minor...........

Demie'je is setera stern.

C'uncism? leucigetris.

Orthorhamphus m:gnirostis.

Thaluseus beryit pelecanoides.

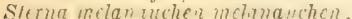

A nous stolidus pileatus. .

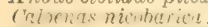

Chaleophnps in lic indica.

Mfyrivicitorabicoles.

irusudicures aeir us polials .

Den-lrophasan ecringis adina.

Loriculus galoulus.

Connerus longicululus.

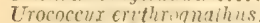

Saurupt is chlorris cymesechs.

Alcedo ispida bengalensis.

Cois rufilursus rufulorsus.

Micropus sulfurcatus.

Collocalit lori...

Colnealia vestite amechand.

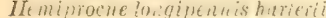

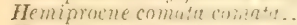

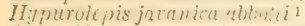

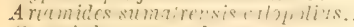

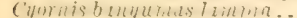

Hypothymis azuron op isth.rivenci 1

A egithina viridissima thapsina ${ }^{1}$.

Pyenomitus plumusals cherounthis.

$I^{\prime} y$ cronuits simplex halizonus..

Pycnonotus brunners zapolius.

Iforizilles in tullirutrits.

Anuropsis malaccersis malaccensis

I/isoritio pilutata zojhere.

Tintacinch matribaricn ochroptiln i

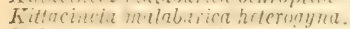

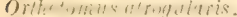

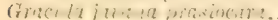

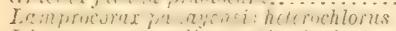

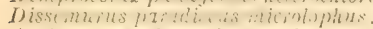

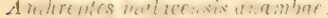

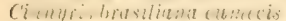

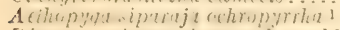

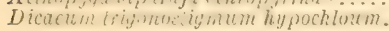

Totals (including both $\Lambda$ namba forms and nearest relatives)

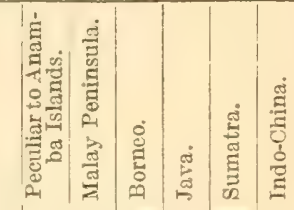

Name. 


\section{ANNOTATED LIST OF BIRDS.}

\section{Family FREGATIDAE. \\ * FREgata MINOR MINOR (Gmelin).1}

[Pelecanus] minor Gmeur, Syst. Nat., vol. 1, pt. 2, 1789, p. 572 (no locality: type region designated by Rothschild as eastern half of Indian Ocean).

Observed in the Anamba Islands by C. B. Kloss, ${ }^{2}$ but not reported by Doctor Abbott.

Family ARDEIDAE.

* BUTORIDES JAVANICUS JAVANICUS (Horsfield).

Ardea Javanica Horsfield, Trans. Linn. Soc. Lond., vol. 13, 1821, p. 190 (Java). Recorded from the Anamba Istands by C. B. Kloss. ${ }^{2}$

* DEMIEGRETTA SACRA SACRA (Gmelin).

[Ardea] sacra Gmelin, Syst. Nat,, vol. 1, pt. 2, 1789, p. 640 (Tahiti Island, society Islands).

Recorded from the Anamba Islands by C. B. Kloss. ${ }^{2}$

\section{Family BUTEONIDAE. \\ * Cuncuma leucogastris (Gmelin).}

[Falco] leucogaster GmeLiN, Syst. Nat., vol. 1, pt. 1, 1788, p. 257 (no locality: type-locality given by Mathews as New South Wales, Australia).

No specimens of this species were obtaned, but it was observed by Doctor Abbott on Pulo Risbu, August 18, 1899; on Pulo Sinnt:m between August 19 and Siptember 13, 1899 ; on I’ulo Tulagi:, Sopt mber 14 to 15, 1899; and on Pulo Jimaja between Stptrimber $1 \%$ ant 28, 1899 .

\section{Family ARENARIIDAE.}

ARENARIA INTERPRES OAHUENSIS (Bloxham).

Tringa oühuensis Bloxнaм, in Byron's Voy. Blonde, Sandwich Ids., 1826, p. 251 (Sandwich [i. e, Hawaiian] Islands).

One male, No. 171011, U.S.N.M.; Pulu Mrta, August 29, 1899.

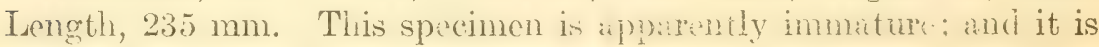
molting some of the wing feathers.

Mr. Mothows is apurently quite right in supurating the Pacific turnston from thet of Europe, ${ }^{3}$ for it cliffers from ties linter, as he says, in smallere size and drepre siede of the chestmut-colored portions of the upper surface. The earliest arailible name is that selected by Mr. Mathews and here used. It might be well to mention, however, that if the date of Pallas' "Zoographia Rosso-Asiatica" be 1811 , as some contend, the proper subspecific derignation of this turnstone would probably be cinclus, from Charadrius cinchus Pallas. ${ }^{4}$

1. Species prefixed with an asterisk are not represented in Doctor Abbott's collection.

2 Journ. Straits Branch Roy. Asiatic Soc., No. 41, January, 1904, p. 80.

${ }^{3}$ Birds Australia, vol. 3, pt. 1, Apr. 2, 1913, pp. 5-10.

4 Zoogr. Rosso-Aslat., vol. 2 (1811?), 1826, p. 148 (Siberia). 


\section{Family CHARADRIIDAE. \\ * Pluvialís dominica fulva (Gmelin).}

[Churadrius] fulvus Gmelin, Syst. Nat., vol. 1, pt. 2, 1789, p. 687 (Tahiti Island, Society Islands).

Recorded from the Anamba Islands by C. B. Kloss, ${ }^{1}$ but not noted by Doctor Abbott.

\section{PAGOA LESCHENAULTI (Lesson).2}

Charadrius Leschenaultii Lesson, Dict. Sci. Nat., vol. 42, 1826, p. 36 (Pondichery, India).

Ch[aradrius]. Gcoffroyi WAglen, Syst. Avium, 1827, Charadrius, No. 19, p. 61 (Pondichery, India; and Java).

Three adults in winter plumage, as follows:

MaI. No. 171033, U.S.N.M.; Pulo Kelong. August :30, 1899. Length, 209.5 mm. "Bill black; feet slaty."

Mil.. No. 1770:32, U.S.M.M.; Pulo Kolong, Lugust 30, 1899. Length, $219 \mathrm{~mm}$. "Iris dark brown; bill bluck; tarsi slaty; toes blackish."

Fomil. No, 171031, Ii.S.N.M.; Pulo Kelong, August 30, 1899. L."ngth 21:3 mm. "Bill bhak; legs greenish slaty; tous blackish."

All of these birds are in process of molt.

The present species is unloubtedly not a member of the same gennis at is chardivius asiaticus Pallas, the type of Eupoda. The use of the name Pagoa has already been explained. ${ }^{3}$

CIRIEPIDISMUS ATRIFRONS (Wagler).

Ch[aradrius]. atrifrons WAGLER, Isis, 1829, p. 650 (Bengal, India).

Ch[aradrius]. inconspicuus WAGLER, Isis, 1829, p. 651 (Bengal, India).

Charadrius pyrrhothorax Goucd, Birds Europe, vol. 4, 1837, pl. 299.

Aegialitis pamirensis RicrMond, Proc. U. S. Nat. Mus., vol. 18, July 25, 1896, p. 589 (Tagdumbash Pamir, central Asia).

\section{Seven specimens:}

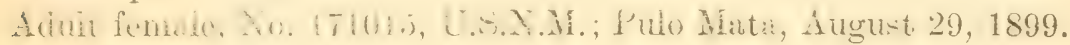
Length, $190.5 \mathrm{~mm}$.

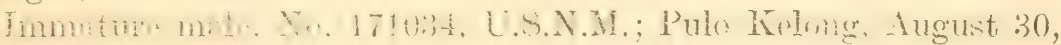
1899. Length, $197 \mathrm{~mm}$. "Teet blackish slaty; bill black."

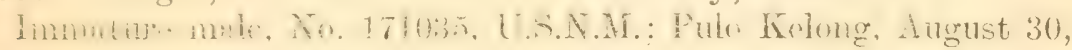
1899. "Feet dark slaty; iris dark brown."

Mrle in juvenal pluminge, No. 171018, U.S.N.M.; Pulo Mata, August 29, 1899. Length, $203 \mathrm{~mm}$.

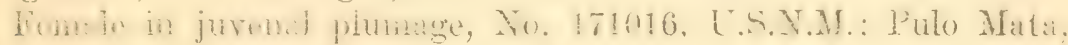
August 29, 1899. Length, $216 \mathrm{~mm}$.

Female in juvenal plumage, No. 171014, U.S.N.M.; Pulo Mata, August 29, 1899 . Longth, $190.5 \mathrm{~mm}$.

\footnotetext{
1 Journ. Siruts liranch Ioy. Isiatic Soc., No. 11, January, 1904, p. 80.

"For this chang" of sij cife name, see 1.atheves, I nu, vol. 16, July, 1916, p. 34

5 See hathew:s, I3ir.js Atustralia, vol. 3 , pt. 1, Apr. 2, 1913, pp. 81-\$4.
} 
Female in juvenal plumage, No. 171017, U.S.N.M.; Pulo Mata, August 29, 1899. Length, $184.5 \mathrm{~mm}$.

Immature male, No. 171034, U.S.N.M., is practically adult except for the incompleteness of the cinnamon breast-band and collar, and the brown, black, and white mottled condition of the milsk. The other immature male (No. 171035, U.S.N.M.), is identical with the adult female except for the presenee of many dusky feather's on the white forehead.

The male in juvenal plumage (No. 171018) is apparently just like the three juvenal females, and has bufiy-suffused lower parts and buffy-edged upper parts.

The specific name of this species must apparently undergo another chlange, as already indicated by Mrr. G. M. Mathews, ${ }^{1}$ and the bird now become Cirrepidesmus atrifrons (Wagler); since the Charudrius inconspicuns of Wagler, ${ }^{2}$ the applicability of which was pointed out by the present writer some time ago ${ }^{3}$ is posterior to the Charadrius airifrons of Wagler, ${ }^{4}$ based evidently on the same species. The use of the gencric term Cirmpidesmus Bonaparte for this birt is not an innovation here. ${ }^{5}$

\section{Family SCOLOPACIDAE.}

\section{TOTANUS TOTANUS EURHINUS Oberholser.}

Totanus totanus eurhinus Oвerholser, Proc. U. S. Nat. MLus., vol. 22, 1900, p. 207 (Lake Tsomoriri, Ladak).

One male, No. 171067, U.S.N.M., from Pulo Jinaja, September 24, 1899. Length, $276.5 \mathrm{~mm}$. "Tris dark brown; bill black, pale reddiwh brown at base; feet orange; claws black." This was obtained in an open place in a mangrove swamp.

\section{PISOBIA RUFICOLLIS (Pallas).}

Trynga ruficollis Pallas, Reis. Versch. Prov. Russ. Reichs, vol. 3, 1776, p. 700 (Dauria, Siberia).

Two specimens in autumn plumage:

Male, probably inmature, No. 171013, L.S.N.M.; Pulo Mata, August 29, 1899. Length, $162 \mathrm{~mm}$.

Adult wale, No. 171012, U.S.N.M.: Pulo Mat1at. August 29, 1899. Length, $159 \mathrm{~mm}$.

Specinens of this species in atum plumage are very difficult to distinguish with certainty from eximples of Pisobia minuta in corresponding state, but they are usually paler above, with upper tailcorerts more blackish, and have the lower surface more purrly white, the breast less tinged with ashy.

\footnotetext{
${ }^{1}$ Biris Australia, rol. 3, pt. 1, A pr. 2, 1913, p. 81. ${ }^{4}$ Isis, 1829, p. 650.

Isis, 1829 , p. 651.

: Proc. U. S. Nat. Mus., rol. 22,1900, p. $20 \%$.

${ }^{5} \mathrm{~S}$ ze Mathews, Biris Australia, vol. 3, pt. 1, A pr. $2,1913, \mathrm{pp}) .81 \cdot-84$
} 
Mr. Mathews has recently reduced this species, to a subspecies of Pisobia minuta: ${ }^{1}$ but, as it seens to me, judging from the wellcharacterized differences between the two in summer plumage, upon quite insufficient grounds.

\section{ACTITIS HYPOLEUCA (Linnaeus).}

[Tringa] hypoleucos Linnaeus, Syst. Nat., ed. 10, 1758, p. 149 (Sweden).

One adult male, No. 170931, U.S.A.M., from Pulo Siantan, August 24, 1899. Length, $199.5 \mathrm{~mm}$.; "feet pale greenish." Doctor Abbott says that the species was common along the beach. He noted it also on Pulo Telaga, September 14-15, 1899.

A series of some 80 specinens of this species in the Lnited States National Museum, corering all parts of its range, scems to show that there are no recognizable subspecies. Careful comparison of these specinens fails to rereal any differenee in either size or color between birds from western Gurope and those from castern Asia, notwithstanding their great geogranhical separation. Hence, the castem form, Actitis 7npoleued aurita (Lathum), recently sonewhat hesitatingly recognized by Mr. Mathews, ${ }^{2}$ cun not be maintained.

\section{Family OEDICNEMIDAE. \\ * orthorhamphus MAGNirostris (Vieillot).}

Oedicnemus magnirostris VIeILlor, Nouv. Dict. d'Hist. Nat., vol. 23, 1818, p. 231 (Geoffroy MS.) (no locality).

Recorded from the Anamba Islands by C. B. Kloss. ${ }^{3}$

\section{Family LARIDAE. \\ THALASSEUS BERGII PELECANOIDES (King).}

Sterna pelecanoides KING, Surv. Intertropical and West Coasts Aust., vol. 2, 1827, p. 422 (Australia).

Two specimens ane in the collection, both nearly adult, bat showing still some immaturity in the whitish crown, brown prinuries, and a fow brownish foatices in the wing-coperts. One of these birds (No. 171029, U.S.N.M.) is molting some of the wing-quills.

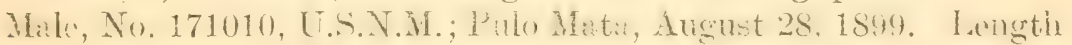
$470 \mathrm{~mm}$. "Bill dirty yellow; iris dark brown; fect black."

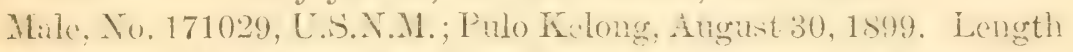

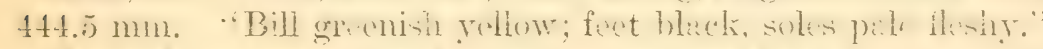

IBoth of these ex:mples belong mquestionably to the moe inhabiting thr East India Istands. For a direnlsion of the status of this form, as well an for the use of the generic nem: Theilestens, eonsult the writer's recent paper on Thalasseus bergii. ${ }^{4}$

\footnotetext{
1 Birds Australia, vol. 3, Aug. 18, 1913, p. 250.

2 Id m, pp. 216-219.

3 Journ. Straits Braneh Roy. Asiatic Soc., No. 41, January, 1504, p. 80.

1 Oberholser, Proc. U. S. Nat. Mus., vol. 49, Dec. 23,1915 , pp. 515-526.
} 
STERNA MELANAUCHEN MELANAUCHEN Temminck.

Sterna melanauchen Temmnck, Nouv. Rec. Planch. Col. d'Oiseaux, vol. 5, livr. $72,1827, \mathrm{pl}, 427$ (coast of Celebes).

One specimen, No. 171030, U.S.N.M., Pulo Kelong, August 30, 1899. A few of the wing-quills are in molt.

This example is identical with others from the Plilippine Islinds, Amoy (China), and Condore Island, and repressuts the typical form of the species, which was described from Calcbes. ${ }^{1}$ Birds collected by Doctor Abbott on the islends off the eastern const of Africa, however, are casily semarable sunspecifically, and as the y litherto have escaped being nomed, all the synonyms of the species having been applied to the typical race, they may be known as

\section{STERNA MELANAUCHEN PROVIDA, new subspecies.}

Subspecific characters. - Similiar to Sterna melaniucticn melanauchen, but upper parts lighter, the mintle of a paler gray; bill longer; wing, tail, and tarsus shorter.

Description.-Type, adult male, No. 128756, U.S.N.M.; Providence Bank, 300 mites southwest of the Sychelles, nort's of Madagascar; Auguit 17, 1892; Dr. IV. L. Abbott. Crown, lind neck, upper tail-coverts, tail, sides of head and neck, with eintire lower parts, including under side of wings, pure white; a spet on lores, and a broad postoculur band, broadening posteriorly and uniting with its fellow across the oeciput, black; heck, rump, scapplatir's, and expesed surface of wings, rery pale pearl gray, this color showing fintly as a narrow stripe along the shafts on the inner weth of the outer few primuries, increasing on the rest of the wing-quilla, which are tipped and margined broally nu inine weds with white; outer wob of first (outermost) primary all but tip and extreme base blnckish slate; bill and feet black.

All the four specinens availahle present little indiridual rariation in either color or size, except, as is, for olrrious reasons, of ten the case with terns, in the length of the tail-fenthers. There secms to be in this species no size difference of consequence betreen males and females.

The geogiaphic range of Siema molnumethen movida comprises the islands of Aldabra and Providence, with doubtless the neighboring islands off the cat Afriean coast, north at least to the Sychelles. The range of the typical form, Strma metanamen metenauchen, extends probably from the Andanian Lamds and Sunatra to the Liu Kiu Islands, Polynesia, and Australia.

The subjoined measurement tables will serve to show the size differences between the two races here defined. 
Measurements of specimens of Sterna melanauchen provida.

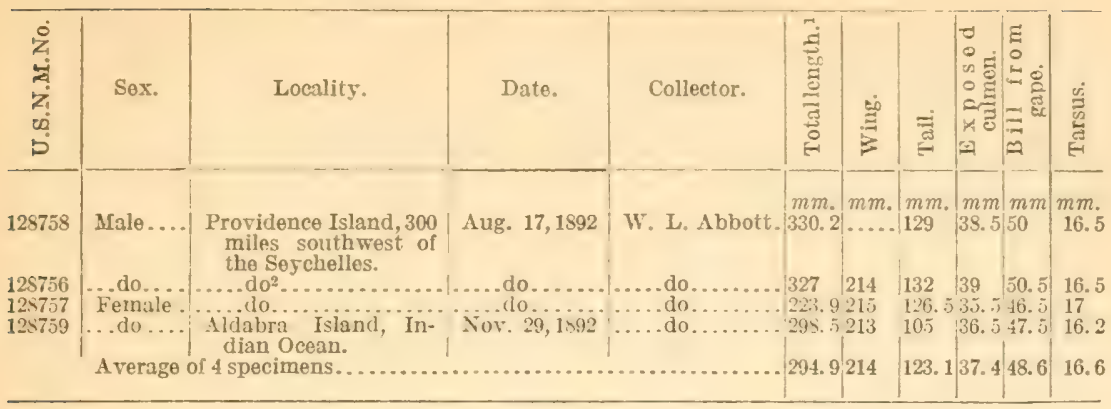

Measurements of specimens of Sterna melanauchen melanauchen.

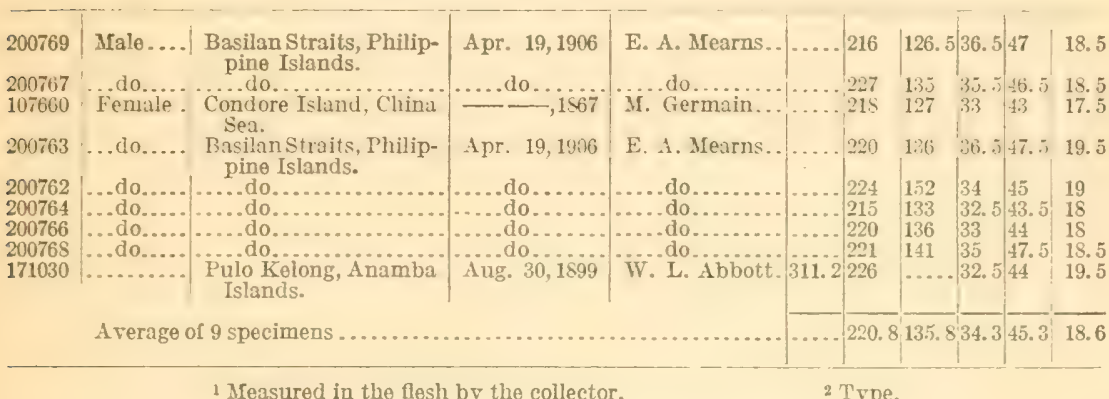

* ANOUS STOLIDUS PILEATUS (Scopoli).

Sterna pileata Scopoli, Del. Faun. et Flor. Insubr., pt. 2, 1786, p. 92, No. 73 (Philippine Islands).

Recorded from the Anamba Islands by Mr. C. B. Kloss. ${ }^{3}$

\section{Family CLARAVIIDAE. \\ * CAlOENAS NICOBAPICA (Linnaeus).}

[Columba] nicobariea Linxaeus, Syst. Tat., ed. 10, vol. 1, 1758, p. 164 (Nicobar Islands, Bay of Bengal).

Recorded from the Anamba Islands by C. B. Kloss, thut not obtained by Doctor Abbott.

\section{CHALCOPHAPS INDICA INDICA (Linnaeus).}

[Columba] indica Linnaeus, Syst. Nat., ed. 10, vol. 1, 1758, p. 164 (eastern India).

One specimen, No. 170992, U.S.N.M., from Pulo Mohur, August 25, 1899. Length, in flesh, $254 \mathrm{~mm}$. "Feet, dark purple red: bill, coral red; cere, dull purple." This hird is apparently identical in size and color with specimens from the Malay Peninsula.

\footnotetext{
3 Journ. Straits Branch Roy. Asiatic Soc., No. 41, January, 1904, p. 80. 
BULLETIN 98, UNITED STATES NATIONAL MUSEUM.

\section{Family TRERONIDAE.}

\section{MYRISTICIVORA BICOLOR (Scopoli).}

Columba bicolor Scopolr, Del. Flor. et Faun. Insubr., pt. 2, 1786, p. 94 (New Guinea).

Five specimens in perfect plumage, although the white areas are more or less soiled:

Adult female, No. 174663, U.S.N.M; Pulo Rittan, May 21, 1900. Length, $400 \mathrm{~mm}$. "Bill blue, black at tip; feet pale blue, claws black."

Adult female, No. 170901, U.S.N.M.; Pulo Piling, August 17, 1899. Length, $394 \mathrm{~mm}$.

Adult male, No. 170902, U.S.N.M.; Pulo Piling, August 17, 1899. Length, $394 \mathrm{~mm}$.

Adult male, No. 170900, U.S.N.M.; Pulo Piling, August 17, 1899. Length, $381 \mathrm{~mm}$.

Adult male, No. 170903, U.S.N.M.; Pulo Piling, August 17, 1899. Length, $407.5 \mathrm{~mm}$. "Iris dark brown; bill pale blue, black at tip; feet light blue, claws black."

These all appear to be identical, both in size and color, with birds from the Philippine Islands, Celebes, and Sumatra. Two of our birds, Nos. 170900 and 170901, have a few spots of blackish on the lower tail-coverts, but the others have this part immaculate. Doctor Abbott says that on Pulo Piling, August 17, 1899, this species was "common, feeding in flocks of 12-15 upon wild fruit trees." On an islet off Pulo Mobur, from August 24 to September 1, 1899, a few individuals came to roost at night. This pigeon was seen also on Pulo Riabu, August 18, 1899.

\section{MUSCADIVORES AENEUS POLIUS, new subspecies.}

Subspecific characters.--Similar to Muscadivores aeneus aeneus, from Borneo, but averaging somewhat smaller, tail more greenish (i. e., less bluish); pileum and nape paler, more grayish (less vinaceous); and lower parts slightly paler.

Description.-Type, adult male, No. 170923, U.S.N.M.; Pulo Siantan, Anamba Islands, August 20, 1899; Dr. W. L. Abbott. Head, throat, and cervix, vinaccous gray, the lower part of the cervix nearly pure gray; chin, extreme anterior part of forehead, and orbital ring, cream white; remaining upper parts metallic bluish green, with a strong bronzy sheen; tail bluish green, with a slight metallic sheen, the middle pair of rectrices most decidedly blue; tertials metallic green like the back; primaries and secondaries dull brown on basal two-thirds of inner half of inner webs, glaucous greenish slate color on remaining portions, the outer vanes of secondaries 
with more or less metallic green gloss; primary coverts and exterior greater coverts greenish slate with some metallic green on outer webs; rest of wing-coverts metallic green like the back; crissum deep maroon-chestnut; remainder of inferior parts cinereous with a slight vinaceous tinge, particularly on lower breast and abdomen; under surface of wing-quills fuscous; lining of wing plumbeous; "inis dark red; eyelids deep red: bill leaden: core purplish red; feet pamplish; claws leaden."

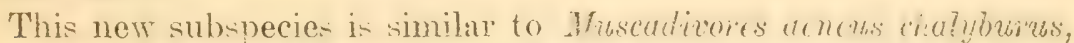
from the Philinpine Island , bat differs in haring the gray of the head less sharply defined from the metallic green of the back: the josterior lower parts less vinaceuts (more elearly grayi-l!): the wiper surface of the tail nearly always brighter, le-s glnucons, nore bluish green. All the Anamba Islands pecimens are fairly uniform in characters, thongh two of them, No. 170925, U.S.X.M. and Xo. 1716it, L.S.X.M., have the tail above less bluish than the others, this approaching Muscadiron acheus chalyburus. Males and femalew are identiral in color. The colors of the soft parts in a male from Pulo Mata (Ao. 171019, U.S.X.M. are given as follows: "Bill leaden, pale dat lip, dark at base; cere dull purple; feet purple." The -ame in a female from Pulo biantan (No. 17.924, T.S.N.M.) are: "Tris darl red; eyclids red; feet purple, soles pale brownish; bill leaden: cere reddish." The weight in flesh of each of two male ( 17.925 , and

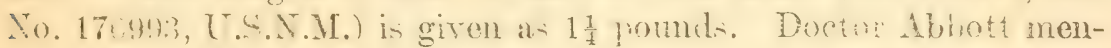
tions that he found the species common in the forest on Pulo

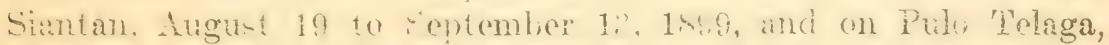
Sejtember 14-15, 1sin. He observed it alco on Prilo Mrngum, “entember 1-2, 1899, and on Pulo Jimaja, September 17-28, 1899.

Measurements of all the specimens obtained are subjoined.

Measurements of specimens of Muscadivores aeneus polius.

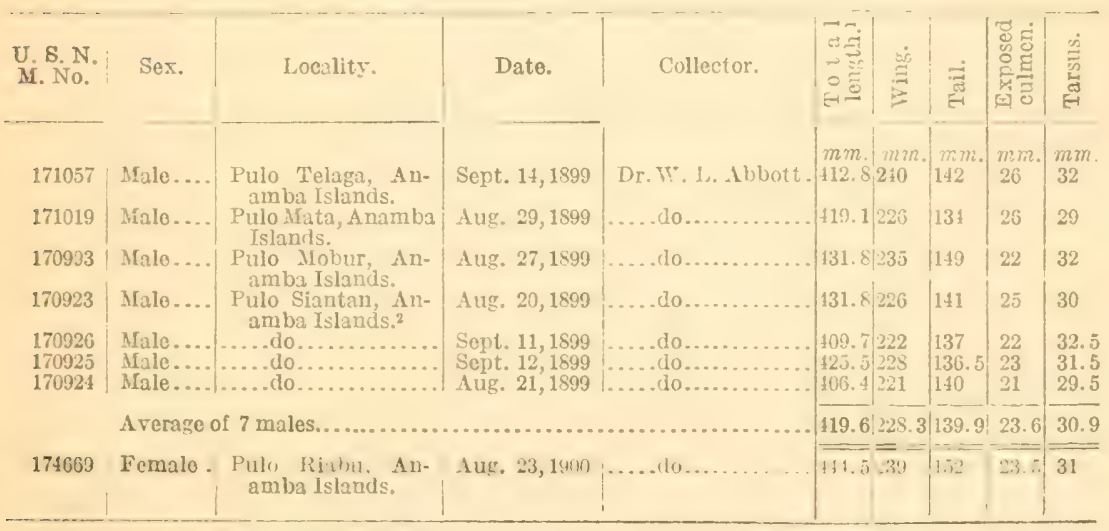


DENDROPHASSA VERNANS ADINA, new subspecies.

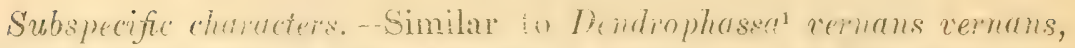
from the Phili, , ine ilands, bit much larger; male duller, arenging le:s grep:ith aline, and of a decidediy paler yellow on abdomen; femals areragng duller, much lew greenish (more plumbeons) above, and mucit paler, dullor, less greenish and yellowish below. the center of abdomen generally whitish.

Deseription. Type, adult miale, No. 171020, U.S.N.M. : Pulo Mata, Anamba Islinds, August 29, 1 s99; Doctor T. L. Abbott. Pileum, sides of head, chin, and throat, plumbeons, rather darker on occiput, the post-oculur region washed with rinicenus; a collar around hind neck and jugulum, broadening on the sides of the throat and neck, vinacoous heliotrope: interscapulum, bark, scipulars, and rump, dull olive green, with a plumbeous wash, and rather brighter posteriorly; upper tail-coverts isubello color, cradually merging into the olive green of rump; tril slate ray, with a broad subteminal band of black, and tipped nirrowly with slate color: wing-quills, except tertials, whe blark, the outer primaries brownish black distally, all the quilk shading inwardy inte slite gray basally; tertials and wingcoverts grarish olive green, like the back, the bend of wing washed with plunbeons, the greater coverts and tertials conspicuonsly margined divtally on outer wels with pale yellow; chest tawny ochraceous; lower breast and upper ublonen light rellowish apple green; sides deep plumbeous wahed with greenish: lower abdomen and flunks sulphur yellow, the litter hroully streaked with weenish slate color; lower tail-corerts light redrish rhestunt; under wurface of wing, including wing-coverts and axillars, slate gray.

Dortor Abbott obtained six males and five fenales from the islands of Siantan, Matal Mobur, and a sinall islet near Pulo Mobur. The males show no differences in color between specinens from the different islands, although there is some individual variation in the depth of shades both above and below. The same is true of the females, but the individual variation in thent is more marked. One female, No. 170928, E.S.N.M. from Pnlo Siantan, is much more greenish above than my of the othere, as well as darker below and withed with brownish across the breast; and it is evidently immature, as the tawny-tipped festhers on the sices of the neek indirate. Lerording to data on the labels of the males, the iris is nometines red, sonetimes in two rings, the inner blue, the outer pink; the feet "red" or "dark red;" "bill leaden; cere yellow." Fomales have the iris yellow, the feet red. On the islet off the coast of Pulo Mobur, where Doctor Abbott took some of these birds. hundrects of them roosted regularly.

1 For the change of tho generic name Osmotreron Bonaparte to Dendropthassa Gloger, see Oberholser, Smiths. Misc. Coll., vol. 60, No. 7, October 26, 1912, p. 2. 


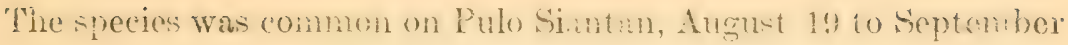
13, 1899; abundant on Pulo MLbur, August 24 to September 1, 1899 ; observed on Pulo Telagi, September 14-15, 1893; and on Pulo Jimaja, September 17-28, 1899.

Following are measurements of all the specimens taken:

Ifeasurements of specimens of Dendrophassa vernans adina.

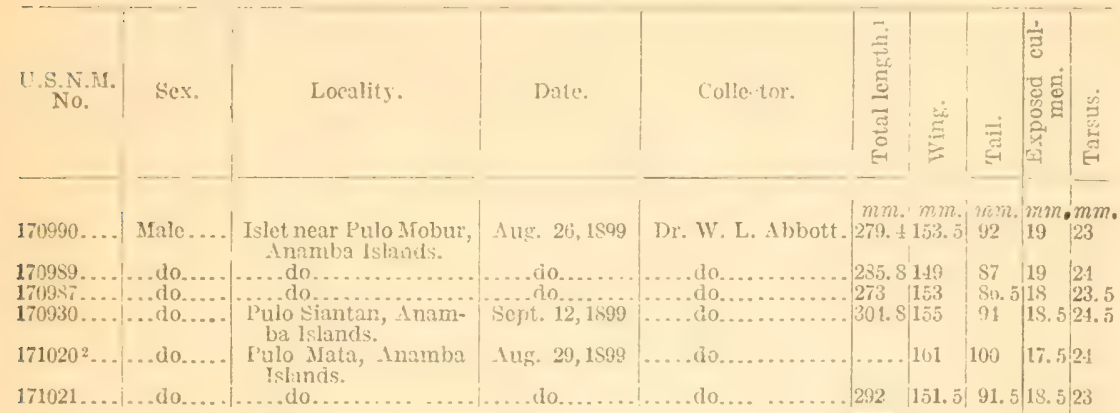

A verage of b males.

25\%.0 153. $5 \mid 91.8 / 18.123 .7$

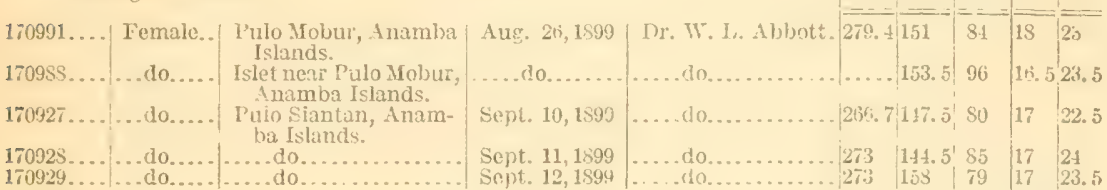

- Irerage of 5 females.

$2 7 3 . 0 1 5 0 . 9 ^ { \prime } 8 1 . 8 \longdiv { 1 7 . 1 2 3 . 3 }$

1 Measured in the llesh by the collecter.

- Type.

\section{Family PSI'TTACIDAE.}

\section{* LORICULUS GALGULUS (Linnaets).}

[Psittacus] Galgulus Linnaeus, Syst. Nat, ed. 10, vol. 1, 1758, p. 103 (India).

Reported from the Anamba Islands by C. B. Kloss. ${ }^{3}$

CONURUS LONGICAULES (Hodelaert). ${ }^{4}$

Psittacus longicauda Boddaent, 'Tabl. Planch. Enlum. d'Hist. Nat., 1783, p. 53 (Malaceal, Malay Peninsula).

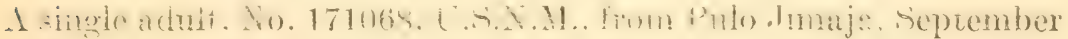
27, 1899. Length, $432 \mathrm{~mm}$. "Iris in two rings-the inner green,

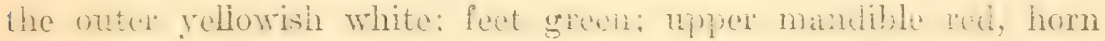
brown at tip; lower mandible horny brown." 'This specimen is

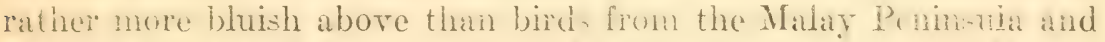
Sumatra, but such is probably only incliridual rariatiun. thetor Abbott states that the species was common on Pulo Jimaja.

\footnotetext{
${ }^{2}$ Journ. Straits Branch IRoy. Asiatic Soc., No. 41, January, 1904, p. 79.

4 For the change of generic name from Palacornis to Conurus, sec Mathars, Novit. \%ool, vol. 18, 19s! p. 11.
} 
Family CUCULIDAE.

\section{UROCOCCYX ERYTHROGNATHUS (Harlaub).}

Dhoenicophaeus erythrognathus Hartlaub, Syst. Verz. Naturhist. Samml. Gesellschaft Mus. [Bremen], pt. 1, 1844, p. 95 (Sumatra).

One adult male, No. 170932, U.S.N.M., from Pulo Siantan, taken in heavy forest, September 11, 1899. Length $\frac{1}{1} 77 \mathrm{~mm}$.; "iris blue; naked orbital skin red; bill green, base dull red; feet dark leaden." In both size and color it is identical with birds from the Malay Peninsula.

Dr. C. Parrot's recent reference of this species to the genus Rhamphococcyx ${ }^{1}$ is not ralid, since Urococcyx is generically distinct, as the structure of the nostrils well shows.

\section{Family ALCEDINIDAE. SAUROPATIS CHLORIS CYANESCENS Oberholser.}

Sauropatis chloris cyanescens OBernotSer, Proc. U. S. Nat. Mus., vol. 52, February 8, 1917, p. 189 (Pulo Taya, eastern Sumatra).

Two specimens of this recently described race are in the collection-an adult male from Pulo Mobur, August 26, 1899; and an immature male from Pulo Mata, August 28, 1899. The latter is rather more greenish on the upper parts than the adult, has the crown somewhat more brownish, the forehead with whitish edging?; the white feathers of the breast tipped with dusky; and it is also somewhat smaller. Both examples are indistinguishable from Bornean specimens. Doctor Abbott saw this kingfisher al:o on Pulo Siantan, August 19 to September 13, 1899.

The generic name Sauropatis Cabanis and Heine is, as already shown, ${ }^{2}$ the proper one for the present species. Of the generic distinctness of this aroup from Halcyon and Ertomethere ${ }^{3}$ there can be little doubt.

Measurements of specimens of Sauropatis chloris cyanescens.

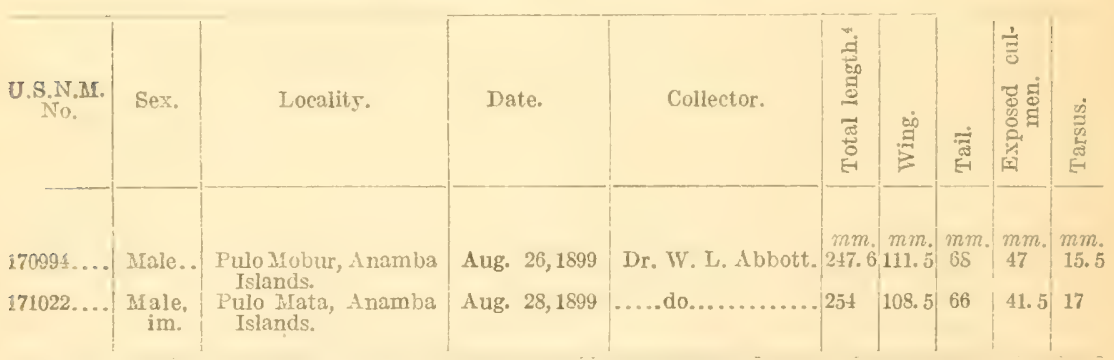

1 A bhandl. k. Bayer. Akad. If iss., II IK1., vol. 21, 1 lbth., 1907, p. 185.

2 Mathew's, Austral A vian Rccord, vol. 1, No. 5, Dec. 24, 1912, pp. 108-109; Oberholser, I'roc. U. S. Nat. E-Ius., vol. 52, February 8, 1917, p. 189.

3 See Oberholser, Hroc. U. S. Nat. Mus., rol. 48, May 18, 1915, p. 0342.

Measured in the flesh by the collector. 


\section{ALCEDO ISPIDA BENGALENSIS Gmelin.}

[Alcedo] bengalensis Gmelin, Syst. Nat., vol. 1, pt. 1, 1788, p. 450 (Bengal, India).

One immature male, No. 174699, U.S.N.M., from Pulo Riabu, August 22, 1900; length in flesh, $172 \mathrm{~mm}$. Doctor Abbott reported this species tolerably common on Pulo Jimaja, September 17-28, 1S99; noted it on Pulo Siantan, August 19 to September 13, 1S99; and on Pulo Manguan, September 1-2, 1899.

Although difference in size appears to be tho only distinction between Alcedo ispida ispida and Alcedo ispida bengalensis, the latter is quite enough smaller to warrant its recognition.

\section{CEYX RUFIDORSUS RUFIDORSUS (Strickland).1}

Ceyx rufidorsa Strickland, Proc. Zool. Soc. Lond., 1846, p. 99 (Malacca).

One adult male, No. 171073, U.S.N.M., from Pulo Jimaja, September 25, 1899. Length, $149 \mathrm{~mm}$. "Iris dark brown; bill and feet coral red. The only one seen; shot on a small creek in jungle; stomach contained insects."

According to the geographical lines that Doctor Hartert has drawn, this bird should be truo Ceyx rufidorsus rufidorsus, but it is rery small for that form, as the wing measures only $57 \mathrm{~mm}$, and the exposed culmen $33.5 \mathrm{~mm}$. It is also paler below than specimens from other localities usually are. Possibly further examples from the Anamba Islands would show these differences to be subspecific.

The Indo-Malayan region from Java and Borneo westward, exclusive of most of the Philippine Islands, possesses the following six forms of this beautiful genus:

1. Ceyx mufidorsus rufidorsus Strickland (= Ceyx euerythra Sharpe; $=$ Ceyx rufidorsa robusta Parrot, Abhandl. k. Bayer. Akad. Wiss., II Kl., rol. 24, 1 Abth., 1907, p. 208). Southern Malay Peninsula, Sumatra, Batu Islands, Linga Islands, Borneo, Labuan Island, Natuma Islands, Anamba Islands, and tho southwestern Philippine Islands north and east to the islands of Mindoro and Sulu.

2. Ceyx rufidorsus innominatus Salvadori.-Islands of Java, Banka, Bali, Kangean, Lombok, Sumbawa, Flores, and Sumba.

3. Ceyx difluymni Sharpo (=Ceyx sharpci Salvadori).-Extreme southem Malay Peninsula (only eastern side?), Kateman Island, Great Karimon Island, Nias Island (teste Salvadori), Borneo, Labuan Island, and southwestern Philippine Islands (Palawan).

4. C'y.e enomopygius Oberholser.-(Ceyx enopopygius Oberholser, Smiths. Misc. Cull., No1. 60, No. 7, Gotober 26, 1912, p. 7 [Aru B:iy, eastem Sumatra]). Eastern coast of Sumatra.

5. Ciys tridactylus didactylus (Pallas).-Ceylois, southerio India, Nopal, and Lower Burigal; rast to Bhutan, Assam, and the Bumese

1 As Doctor Hartert has shown (Novit. Zool., rol. 9, 1902, p. 431), the generic term Ceyx is of masculine, not feminine gender as commonly considered.

2 Norit. Zool., vol. 9, 1902, pp. 430-431. 
provinces; south through the Malay Peninsula to the Mergui Archipelago and Malacca.

6. Ceyx tridactylus macrocarus, new subspecies.

Subspecific characters.- Simitar to Ceyx tridaciylus tridactylus, but decidedy larger?: the Bluish llack forehead spot at base of culmen much smaller, often wanting; and the pileum of a somewhat darker ferruginous.

Description.-Type, adult male, No. 178555, U.S.N.M.; Great Nicobar Island, Nicobar Islands, March 14, 1901; Dr. W. L. Abbott. Pileum and cervix ferruginous, strongly washed posteriorly and laterally with magenta; forehead on each side of the culmen with a spot of ochraceous buff; a conspicuous spot of pale canary yellow on each side of the neck; above this a spot of hyacinth blue; back hyacinth blue; scapulars and wings black, the scapulars, lesser and middle coverts broadly tipped with the same blue; the quills broadly margined interiorly except at tips with tawny ochraceous; bend of wing orange rufous; rump and upper tail-coverts magenta over orange rufous; tail ferruginous, the central feathers tipped with fuscous: chin white: rest of lower parts, including the lining of the wings, rich lemon yellow, paler on the throat, richer on the breast and sides of body: sides of head and neck the same but tinged with tawny; bill bright red.

Measurements. ${ }^{1}$ - Wing, 56-62 (arerage, 58.4) mm.; tail, 22-27.5 (24.3); exposed culmen, 33-35.5 (34.7); tarsus, 8-10 (9.1).

Geographic distribution.- Nicobar Islands: ! Andaman Islands.

Nil the names that hare been applied to Ceye tridacinlus ${ }^{2}$ refer without doubt to the mainland form. All our specimens are from the Island of Great Nicohar, but Ceyx tridactylus macrocarus doubtless oceurs on also other islands of the Nicobar gromb. I have seen no specimens of rare ridactulus from the Andaman Islands, but the species oceurs there, and will probably prore to be of the Nicobar form. There seem to be no differences in color, other than those

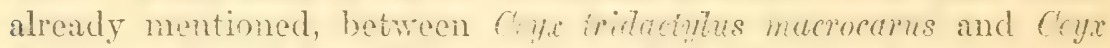
indactylus trituctulies. The small size of the bluckish forehead spot is rery noticenble in the former, so far ats our specimens go; in six of our ten birds this marking is either alsent or reduced to insignificance, while in none of the other's is it so large as is usual in C'tyx

1 No separation of males and females is here made, because their dimensions are practically alike.

2 These are:

Alcedo tridactyla Pallas, Spicel. Zool., fasc. 6, 1769, p. 10, pl. 2, fig. 1 (Surinam [!]; locality wrong; I designate Bengal, India, as type-locality).

Alcedo crythaca Gmelin, Syst. Nat., vol. 1, pt. 1, 1788, p. 449 (Bengal, India).

Alcedo purpurea Gmelin, Syst. Nat., vol. 1, pt. 1, 1788, p. 449 (Pondichery, India).

Ceyx luzoniensis Stephens, in Shaw's Gen. Zool., vol. 13, pt. 2, 1825, p. 106 (new name for Alcedo tridactyle Shaw, Gen. Zool, vol. 8, 1811, p. 104).

Ceyx microsoma Burton, I'roc. Zool. Soc. Lond., 1837 (Feb. 13, 1838) p. 89 (India Maderaspatana).

Boddaert's Alcedo rubra (Tabl. Planch. Enlum. d'Tist. Nat., 1783, p. 48 [Madagascar], is sometimes quoted as a synonym of Ceyr tridactylus, but it is clearly the samo as Is pidina madagascariensis (Linnaeus). 
tridactylus tridactylus. The deeper shade of the pileum and cervix is not wholly constant, but is easily seen in a series. We have thus in Ceyx tridactylus macrocarus another of the large dark races of birds, of which there are so many on the Andaman and Nicobar Islands. The difference in size, particularly of bill and wing, between this new form and typical C'y.i triflactylus is very evident upon eren sumerficial comparison. Eight specimens of Ceyx tridactylus tridactylus from various localities, including the Mergui Archipelago, measure as follows:

Wing, 53.5--.56.5 (arerage, 55.2) mm.: tail, 19-27 (arerage, 22.6); (exposed culmen, 29.5-33 (arerage, 31.6) : tarsus, 6-8.5 (average, 7.7).

The United States National Museum series of C'eyx tridactylus macrocams exhibits the following detailed measurements:

Measurements of specimens of Ceyx tridactylus macrocarus.

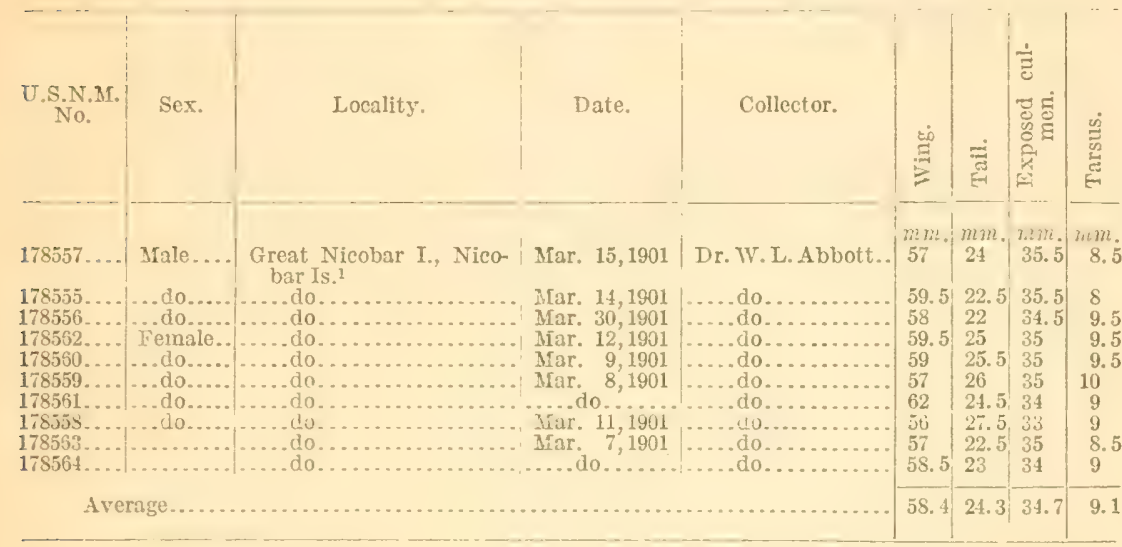

1 Type.

Two groups which are quite as well characterized as many current genern of Deedinidze compose at present the single genus Ceyx. ${ }^{2}$

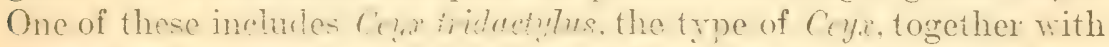

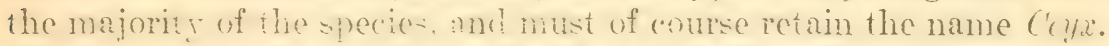

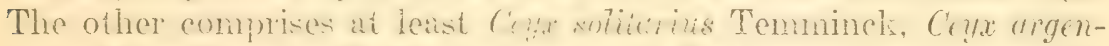

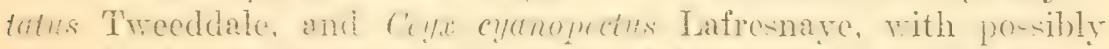
some further forms among those that I have not been able to cx-

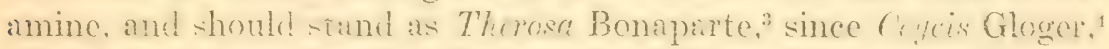

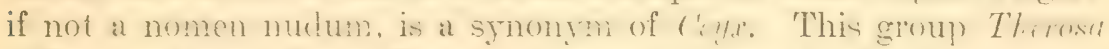
differs strikingly from frat in the murh more slemerte nore eonpressed bill, the ontlines of which, both haterily and rertically, are

2 The generic name Cey.x is commoniy cited from Lacépède, Mrém. l'Inst. Nat. Scl. et Arts, vol. 3, 1801, p. 511, but the original description occurs in Lacépède's Tableau, Oiscaux, 1799, p. 10 (t)pe, Alcedo tridactyla Pallas).

${ }^{3}$ Therosa Bonaparte, Consp. Gen. Arium, vol. 1, 1S50, p. 158 (Müller mamseript) (type by monotypy, Ceyx solitaria Temminck).

i Gemein. Hand- und Uilísb. Naturg., 1812 (1S11), p. 338. 
less convex, the culmen much more sharply ridged-almost as in Alcedo and Alcyone-and the gonys more decidedly keeled. The three species abore included should therefore be called:

Therosa argentata (Tweeddale).

Therosa solitaria ('Temminck).

Therosa cyanopectus (Lafrosnaye).

\section{Family MICROPODIDAE.}

\section{*MicRopUS SUBFURCATUS (Elyth).}

Cypselus subfurcatus Bцутн, Journ. Asiat. Soc. Bengal, vol. 18, August, 1849, p. 807 (Malay Peninsula).

Recorded from the Anamba Islands by Mr. C. B. Kloss. ${ }^{1}$

\section{COLLOCALIA LOWI (Sharpe).}

Cypselus lowi Sranpe, Proc. Zool. Soc. Lond., 1879, p. 333 (Labuan Island, northern Borneo).

One adult male from Pulo Riabu, Aurust 22, 1900. Length, 133.5 $\mathrm{mm}$.; wing, $134 \mathrm{~mm}$. "Shot out of a flock of nearly a hundred that were hawking along the bcach in the evening." The present example has the tail distinctly though not deeply emarginate; but this can be regarded as senrecly more than an individual peculiarity. Indeed, the shape of the Lail, as a character used to distinguish Cullocatia lowi from Colloctia whitheati, is of dorihtful ralue, for some specimens of the latter hare the tail almost square, white Colloculia lowi sometimes shows distinct emargination.

Mr. Erwin Stresemann has rently described ${ }^{2}$ as a subspecies of Collocalia lowi the form of Contocatia whitcheadi from Palawan Island which the present riter some years ago indicated as possibly separable. This is a bird with linfenthered tarsi, like Collocatia whitcheudi, and chesrly is a subsinceies of that species, not of Collocalia lowi, with which it has nothing to do, and should, therefore, stand

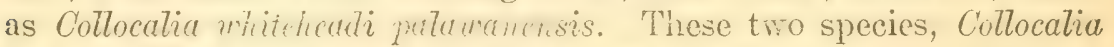
lowi and Collowilie whithuli, are rery similar in coloration, as, indeed, are so many of the other listinct species of this difficult genus, but coltoculia lomi is comenthe darker below than both

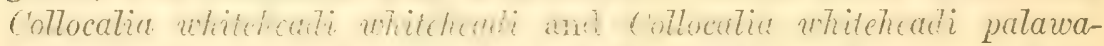
nensis, with more distinct duik shaft streaks and nore uniform coloration, the throat not being noticeally lighter than the breast and abdonim, as is the case in hoth forms of Col7octial whitheadi. In fact, the most salisinetory neans of distinguishing these two species is the difference in the ferthering of the tarsi. Thus, to

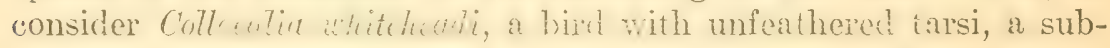

1 Journ. Straits Branch Roy, Asiatic Soc., No. 41, January, 1904, p. 79.

2 Collocalia lowi palawanensis Strosemann, Verhandl. Ornith. Gesells. Bayern, rol. 12, May 15, 1914, p. 10. 
species of Collocutia lowi, a bird with well-feathered tarsi, is clearly doing it violence; and this the more since true Collocalia lowi with fatherd tarsi occurs also on Palawan Island, the very locality from which comes its supposed subspecies palawanensis! This last fact was apparently orerlooked by Mr. Stresemann in diagnosing Collocatia whiteheadi palawanensis.

The bird from Mindanno Island, described by the writer as Collocatia ori, eris, ${ }^{2}$ which Mr. Stresemann, ${ }^{3}$ without examining any specimens, slagerists is posibly the same as Collocatia whitheadi, is undoubtedly distinc from the latter. That it may erentually prove to be a geographical race of that speceses may well be so; but the original specimens in the United States Tational Nuseum, which, so far as we know, nre all that exist in any collcction, certainly do not indicate such to be the catse. 'This bird has an entirely unfeathered tarsus, like Collocatia whitheriti, of the island of Luzon, but differs from that species in its decidenly darker, more blackish, and more uniform coloration above, the rump not being appreciably lighter than the back; and in its slon much darker and nore uniform lower surface, with the throat not noticeably if at all paler than the breast and abdomen, instead of decidedly lighter, as in Collocalia whiteheadi whiteheadi and Collnertin whitcharib malarensis. In fact, Collocatia origenis is dechievily darker above than eren Collocutia lowi, and fully as dark and miform, in some specimens darker, below than is that species; ant in the genera! aspect of its coloration is really more like Collocatia Towi inan like Cullocatin whitheadi. It is, howerer, of course, readily separithle from the former by its unfeathered tarsi, and also by the almost total absenee of blackish shaft-lines on the ferthers of the posterior lower parts, in addition to the color diffeiences already noted.

COLLOCALIA VESTITA AMECHANA Oberholser.4

Collocalia fuciphaga amechana OBerholser, Proc. U. S. Nat. Mus., vol. 42, March 6, 1912, pp. 12, 13 (Pulo Jimaja, Anamba Islands).

Docior Abbott obtained only two specimens of thi- swiftlet:

Adult fomale, Nu. 171071, U.S.N.M.; Pulo Jimajar, Sejt:mber 19 , 1899. Length, $127 \mathrm{~mm}$.

Adult fomale, Wo. 171072, I.S.X.M.: Pulo Jimaja, Seintember 19, 1899. Length, $124 \mathrm{~mm}$.

The-e are both more or less in process of molt. 'They have been fully dism-sed in previous papers." "The second specimen mentioned above is the type of the subspecies.

1 Sec Crant, Ibis, 1895, p. 460.

2 P'roc. Aca\}. Nat. Sci. Plilia., July 25, 1906, p. 191

3 Verhandl. Ornith. C'sells. Mayern, vol. 12, May 15, 1914, p. 11.

I For tiic el:ange of specitic name, see Stresemann, Verhandl. Ornith. Ges. Bayerm, vol. 12, May 15, 1914, pp. $2-6$.

5 Olierinolser, I'roe. Acad. Nat. Sci. l'inila., 1906, p. 189; P'roc. U. S. Nat. Mus., vol. 42, Mar. 6, 1912, p. 13. 


\section{Family HEMIPROCNIDAE.}

\section{HEMIPROCNE 1 LONGIPENNIS HARTERTI Stresemann.}

Hemiprocne longipennis harterti StresemanN, Novit. Zool., vol. 20, June, 1913, p. 339 (Deli, northeastern Sumatra).

Two specimens:

Actult male, No. 171070 , U.S.N.M.; Puln Jimaja, September 25, 1899. Length in flesh, $210 \mathrm{~mm}$. "Feet dark brownish purple."

Adult fomale, No. 171069, L'.S.N.M.; Pulo Jimaja, September 18, 1899.

Both are in process of molt, and though somewhat worn, seem to be identical with birds from Sumatra and the Malay Peninsula, which represent this newly described and readily distinguishabli race. Doctor Abbott reports that this hird was common in the mangrore swamps of the Anamba Islands.

There are now recognizable the following forms of Hemiprocne Tungipennis:

Hemiprocne longiperinis longipennis (Rafinesque).--Islands of Java and Bali.

Itemiprene Tongipennis herterit Stresemann.--Islands of Sumatra, Banka, Billiton, anil Bonen, north to the Natuna Islands, Anamba Islands, the Malay Peninsula, Tenasserim, and Burma.

Memiprocne Tongipenis thou Oberhoiser. -Batu Ishands, Barussan Chain, western Sumatra.

Hemiprocne Iongipennis peronya (Richmond).--Simalur Island, Barussan Chain, western Sumatra.

Ileminocne longipennis achntem therholser. - Nias Island, Ba. russan Chain, western Suniatra.

\section{* HEMPROCNE COMATA COMATA (Temminck).}

Cypselus comatus Temmincr, Nouv. Rec. Planch. Col. d'Oiseaux, vol. 4, livr. 45, $\Lambda$ pril, 1824, pl. 268 (Sumatra).

Noted in the Anamba Islands by ('. B. Kloss, ${ }^{2}$ but not reported by Doctor Abbott.

\section{Family HIRUNDINIDAE.}

\section{HIRUNDO RUSTICA GUTTURALIS Scopoli.}

Hinundo gutturalis Scopour, Del. Flor. et Faun. Insubr., pt. 2, 1786, p. 96 (based on Sonnerat, Voyage a la Nouvelle Guinée, p. 118, pl. 76; type-locality, Antigua, Panay Island, Philippine Islands).

Dowtor Abbott obtaince but a single sinecinem of this migrant swallow-a jurenal male (No. 1710!3. L.A.......) froin Pulo Jimaja, taken on September 26, 1899.

1 For the use of the generie name Hemiprocne Nitzsch in place of Af cropteryx Swainson, see Oherholsir. 1'roc. Biol. Soc. Wash., vol. 19, May 1, 1900, pp. 67-69.

2.Joura. Straits Branch Roy. Asiatic Soo, No. 11, Jamuars, 1901, p. 79. 
The comparison of the above specimen with examples of this and allied forms has led incidentally to an examination of ITivundo rustica rustica, Hirundo mustica transitiva, Hirundo serignii. IIimendo gutturutis, Timudo tyfleri, and IIirundo emihrogastris, with particular reference to their relationships with each other. After careful study of the specimens in the United States National Museum and of the literature on the subject. I am led to consider them all geographical races of one succies, and thus to agree completely with the riew expressed by Dr. R. B. Sharpe ${ }^{1}$ and more recently by Dr. E. Hartert." "This is also the same opinion as that held by Mr. Henry Seebohm, ${ }^{3}$ except that he unites ITimndo tyfleri with Mirundo erythrogastris.

That Hirundo mstice rustica, with its usually unbroken lark jugular band, intergrades with the brolen-banded IIirundo rustica gutturatis, both geographically and individualty, there seems to be not the slightest reason to doubt. for there are altogether too many intermediate sperinens. Furthermore, some of the darker examples of Hirundo mestica gutturalis are exceedingly close to the lighter suesimens of IItrurdo rustica empthrogastris, and are difficult to distinguish without actual comparison: in fact the two forms orerlap inclividualy in all characters. Similarly, the dark extreme of Mirunto mestica crythogustris overreaches intividually the light extreme of Ifirundo rusica tytleri, and thus connects these two forms.

After careful examination and comparison of a large series of

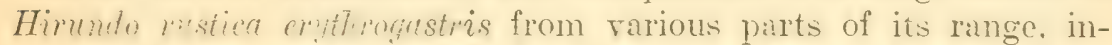
cluding a consitcruble series from western dlaska, I an cutirely mahle to see any even arerage differences which entitle the Alaska birl to subupecific separation as II imm to erythrogastra pulmeri; ${ }^{4}$ since all the supposed lisine: ions of both size and color seeni to be merely individual variations.

Rererting again to Iimume rustica tytleri, it is crident that intermedintes between this and Timulo metica gntturalis would be practically indistinguishable from Irirunde) resticu erythrogetstris: and that such intergalation actualy takes place in northeastern Siberia where the breceiting zange of Hirundo rustice tifteri approaches that

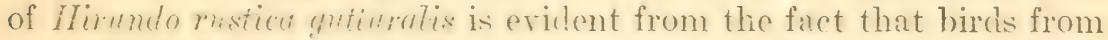
Lake Baikal are practically like specimens of Mimude rustica cr!ythregrestris. although for gengraphical reasons referable of course to Itimude ristien gutturutis: and from the rarious winter specimens from Burma and Cochin (hina that so closely resemble Ifirumbo rustice crotleregastris that Doxtor Sharye and others have identified them as such.

\footnotetext{
1 Cat. Birds Brit. Mus., vol. 10, 1S55, pp. 126-140.

2 Vögel paläarctischen Fauna, vol. 1, 1910, pp. 800-801.

3 Hist. Brit. Bir ls, vol. 2, 18s4, pp. 171-172.

4 Grinnell, Condor, vol. 4, May 15, 1902, p. 71 (Amalmak Island, Unalaska Harbor, Alaska).

s Seo Sharpe, Cat. Birls Brit. Ifus., vol. 10, 18S5, p. 127.
} 
The breeding bird of Egypt, Hirundo rustica savignii, while very different from Hirundo rustica rustica, is so close to the widely separated Hirundo rustica tytleri that individual variations overlap all the subspecific characters. Furthermore, Mirundo rustica transitiva, from Palestine, is a connecting form between Hirundo rustica savignii and Hirundo rustica rustica. From the above statements it is obvious that all six of these forms of Hirundo are subspecies of Hirundo rustica. Their characters and ranges are as follows: ${ }^{1}$

1. Hirundo rustica rustica Limnaeus.

[Hirundo] rustica Linnaeus, Syst. Nat., ed. 10, vol. 1, 1758, p. 191 (Europe).

Subspecific characters. - Size large; metallic blackish jugular band wide and usually not interrupted medially; posterior lower parts whitish, more or less tinged with rufous or isabella color.

Type locality. - Sweden (restricted by Hartert, $1910^{2}$ ).

Geographic distribution.-Breeds throughout Europe, and west to Iceland, east to western Siberia, Turkestan, and the Himalaya Mountains; south to Baluchistan, Persia, Asia Minor, Tunis, Algeria, and Morocco. Winters south to southern Africa, southern India, the southern Malay Peninsula, the Philippine Islands, and the Molucea Islands. Casual in Greenland.

2. Hirundo rustica gutturatis Scopoli.

Hirundo gutturalis Scopoli, Del Flor. et Faun. Insubr., pt. 2, 1786, p. 96 ("In Nova Guiana, p. 118, Tab. 76").

Subspecific characters.-Similar to Hirundo rustica rusíica, but much smaller; blackish jugular band usually divided by the chestnut of throat; posterior lower surface averaging moro whitish.

Type-locality.-Antigua, Panay Island, Philippino Islands.

Gcographic distribution.-Breeds in northeastern Asia, north to the Siberian provinces of Amur, Transbaikalia, and Trkutsk; west to Irkutsk and northern China; south to northern China and to Korea; and east to Japan. Winters south to southorn India, the Malay Peninsula, Sumatra, Java, the Molucca Islands, New Guinea, and occasionally northern Australia.

3. Hirundo rustica tytleri Jerḍon.

Hirundo Tytleri Jerdon, Birds of India, vol. 3, 1864, p. 870 (Dacca, Bengal India).

Subspecific characters.- - Similar to Hirundo rustica gutturalis, but rather larger; posterior lower parts rufous chestnut instead of usually whitish; white spots on the rectrices, together with the concealed white subterminal portions of the dark feathers of the upper surface, more or less tinged with buff, instead of practically pure white.

Type-locality.-Dacca, Bengal, India.

1 For the synonymy of these birds, see Sharpe, Cat. Birds Brit. Mus., vol. 10, 1885, pp. 128-140; and Hartert, Vögel palïaretischen Fauna, vol. 1, 1910, pp. 800-\$04.

2 Vögel paläarctischen Fauna, vol. 1, 1910, p. 800. 
Geographic distribution.-Breeds in Kamchatka and other parts of northeastern Siberia; and migrates west to Irkutsk in central southern Siberia. Winters south to southern China, Pegu, and Tenasserim.

\section{Hirundo rustica erythrogastris ${ }^{1}$ Boddaert.}

Hirundo erytlirogaster Bodda ErT, Table Planch. Enlum., 1783, p. 45 (Cayenne).

Subspecific cheructers. - Sinilar to Thimendo rustica tylteri, but areraging decidedly paler on the lower parts; white tail-spots and white subterminal portions of feathers of upper paris less strongly tinged with buff; and size somewhat smaller. Resembling Ifirundo rustica. gutturatis, but throat areraging paler; remaining lower parts more heavily shaded with fulvous; tail-spots and concealed white subterminal portions of feathers of upper surlace more or less tinged with buft. Differs from Ilirundo rustica rustica as Irom IFrundo rustica gutturatis, and additionally in smaller size and interrupted blackish jugular band.

Type-locality.-Cayenne, French Guiana.

Geographle disiribution.-Breeds in North America, east to the Atlantic Ocean; north to central Quebee (southern Ungava), northern Mackenzie, and norihwestern Alaska; west to the Pacific Ocean; and south to the States of 'Tepic and Jalisco (Mexico), southern Texas, and North Carolina. Winters south to Chile, Argentina, and Brazil. Casual or accidental in Greenland, the Galapagos and the Bermuda islands.

5. Hirundo rustica transitiva Hartert.

Hirundo rustica trunsitiza Hartefit, Vögel paliarctischen Fauna, vo l. 1, June 1910, p. 802 (Plain of Esdralon, Palestine).

Subserecific churacters.--Similar to Himndo mustica mustica, but smaller, and with lower parts much more deeply rufescent.

Type-locatity.-Plain of Esdralon, Palestine.

Geographic distribution.-Palestine.

6. Hirundo rustica savignii Stephens.

Hirundo Savignii Stephens, in Shaw's Gen. Zool., vol. 10, pt. 1, 1817, p. 90 (Egypt).

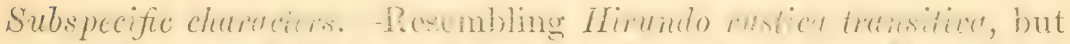
lower suriace much darker, of a rieh rufous chestint. Fery much

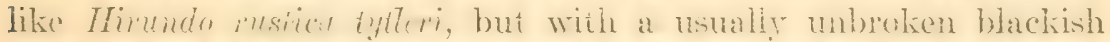
jugular band, and derper tawny buff suffusion on the light tail-spots and the white concealed subterminal portions of the feathers of the upper surface.

Type-locality.-Egypt.

Geographic distribution.-Egypt and Nubia.

1 The subspecific term erythrogaster as here used is a Latin adjective of the third declension, and therefore has for its proper feminine nominative erythrojastris, not erythrogastra, as commonly written. 
The name Chetidon Forster has recently been revived by Dr. E. IIarte ${ }^{1}$ as the proper generic appellation for IIirundo mater and its allies, on the ground that Schaeffer ${ }^{2}$ did not fix the trye of Himento ats Hirundo rusica, and that Forster, ${ }^{3}$ as the first author to subdiride the group, thereby determined its type. While it is quite true that Schaefer in 1774 did not iil the modern sense fix the y ype of the genu- Himindo, it is likewise true that the action of Forster in merely applying different generic names in sereral of the species is equally of no effect. The International Code of Nomenchature provides that in order to make a type designation ralid an author must definitely indicate a species as the type. So far as we have been able to ascertain, the first designation according to the specifications of the International Code was by Selby in 1825,4 who selected Hirundo mesice as the type; and Gray, in $1840,{ }^{5}$ designated the same species. There is thus open, under the rules, no other course than to consider Hirundo rustica the type of Hirundo Linnaeus.

\section{$\div$ HYPUROLEPIS JAYANICA ABBOTTI, ${ }^{6}$ new subspecies.}

Subspecife characiers. - Similar to IIypurolepis jazanica jaranica, from Jara, but larger; forchead, chin, and throat darker; posterior lower parts more grayish (less brownish), and medially much more whitish.

Description.-Type, adult male, No. 171048, U.S.N.M.; Pulo Manguan, Lnamba Islands, September 1, 1899; Dr. W. L. Abbott. Forehead and sinciput bay; rest of upper parts shining metallic dusky bluish green; rectrices brownish black, their upleer surface more or less glossed with metallic deep green, all but the middle pair with a conspicuous subterminal transverse spot of white; whing brownish black, the exposed surface glossed with metallic green like the tail, the lesser wing-coverts edged with the metallic bluish green of the upper parts, and tertials with minute buffy tips; chin and throat between russet and tawny; sides and flanks hair brown, many of the feathers with paler tips; breast paler brown, the leather's with light tips; middle of abdomen brownish white, the central portion of the feathers mostly pale brownish with dark shaft lines; lower tailcoverts fuscous, the subterminal portions black, the tips buffy; lining of wing fuscous, with minute russet edgings; "iris dark brown; bill and feet black."

\footnotetext{
1 Vögel paläarlstischen Fauna, vol. 1, pt. 6, June, 1910, pp. 800-801.

2 Elem. Ornith., 1774, Classis II, Ordo VII, pl. 40.

3 Synop. Cat. Brit. Birds, 1817, p. 17.

1 Illustr. Brit. Ornith., pt. 1, 1825, p. xxviir.

5 List Genera Birds, 1810 , p. 8.

6 Named for the collector and donor, Dr. Wr. L. Abbott.

7 Hirundo javanica Sparrman, Mus. Carlson, fasc. 4, 1789, pl. 100 (Java).
} 
This new race may be distinguished from Celebes specimens of Hypurolepis jaranica frontulis (Quoy and Gaimard) ${ }^{1}$ by reason of larger size; duller, darker throat; darker, somewhat less brownish sides and flanks; less dull, less brownish, and therefore more strongly contrasted whitish middle portion of abdomen. From Hypurolepis jaranica domicola (Jerdon), ${ }^{2}$ which is a recognizable race from southern India. and the Malay Peninsula, Hypurolepis javanica abbotti differs in dulier, darker throat; darker, more grayish (less rufescent) brown of sides and flanks; less brownish tinge of the whitish middle portion of the abdomen, whereby this latter is more sharply in conirast to the lateral brown areas; and in the more conspicuously spotted appearance of the posterior lower surface.

One speeimen (No. 171060, U.S.N.M.), taken on Pulo Telaga, September 14,1899 , is a juvenal male, and differs from the adult in entirely lacking the bay frontlet; in haring the upper parts very much duller, the wings with searcely any metallic sheen; and lower surface very much lighter throughout, the crissum dull brown, without any black. One of the other birds (No. 171090, U.S.N.M.) has the outer printaries in process of molt; and nost of the remaining examples show indieation of molt in the body plumage.

Doctor Abbott reported this species common on Pulo Jimaja, Septamber 17-25, 1599: and obserred it on Pulo Siantan, August 19 to September 13, 1899. He obtained seren specimens on the various islands of the Anamba group.

The subjoined tahle of measurements includes all our Anamba examples of IIypurolepis juranica abbotti, and for comparison some specimens of Hypurolepis javanica javanica from Java.

Measurements of specimens of Hypurolepis jaranica abbotti.

\begin{tabular}{|c|c|c|c|c|c|c|c|c|c|}
\hline $\begin{array}{c}\text { U.S.N.M. } \\
\text { No. }\end{array}$ & Sex. & Locality. & Date. & Collector. & 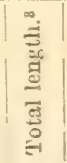 & $\frac{\dot{20}}{\vec{a}}$ & 苛 & 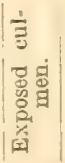 & 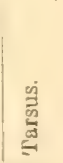 \\
\hline $17102 i \ldots$. & Malt .. & Pulo Mata, Inam- & Aus. 23,1539 & Dr. W. L. Abvott. & $\begin{array}{c}m m \\
139.7\end{array}$ & $\begin{array}{l}m m_{.} \\
109.5\end{array}$ & $\underset{45.5}{m m .}$ & $\underset{9}{m}$ & ${ }_{10}^{m m}$ \\
\hline $171048 \ldots$ & Male.... & Pulo Nanguan, & Sept. 1,1899 & .....do.. & 133.4 & 103.5 & $40^{\circ}$ & 8.5 & 9.5 \\
\hline $171060 \ldots$ & Malo, ju- & $\begin{array}{l}\text { Pulo Telaga, Anam- } \\
\text { ba Islands. }\end{array}$ & Sept. 14, 1899 & .....do... & 133.4 & 103 & 14 & 8.5 & 10.1 \\
\hline $171017 \ldots$ & Female.. & Pulo M a guan, & Sept. 1,1899 & .....do... & 136.5 & 109 & 44 & 8.8 & 11 \\
\hline $171091 \ldots$ & Female.. & Pulo Jimaja, Anam- & Sept. 25,1899 & .....do... & 133.4 & 105 & 43.5 & 7.5 & 10 \\
\hline $\begin{array}{l}171092 \ldots \\
171090 \ldots\end{array}$ & $\begin{array}{l}\text { Female. } \\
\text { Fermale.. }\end{array}$ & 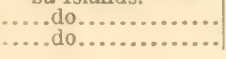 & $\begin{array}{l}\text { Sept. } 26,1599 \\
\text { Sept. } 18,1899\end{array}$ & .....do... & $\begin{array}{l}130.2 \\
136.5\end{array}$ & 110.5 & $\begin{array}{l}46 \\
49\end{array}$ & $\begin{array}{l}8.5 \\
8.5\end{array}$ & $\begin{array}{l}10 \\
10\end{array}$ \\
\hline & 3 of $7 \mathrm{sp}$ & ecimens... & & & & 108.1 & 45.4 & 8.5 & 10.1 \\
\hline
\end{tabular}

$\because$ I Hirundo fronlalis Quoy and Gaimard, Voy. l'Astrolabe, Zool., vol. 1, 1830, p. 201, pl. 12, fig. 1 (Dorey harbor, New Guinea).

2 Hirundo domicola Jerdon, Jfadras Journ. Lit. and Science, vol. 13, pt. 1, No. 30, "A pril, 1844," p. 173 (Nilgiri Hills, southern India).

3 Ifeasured in the flesh by the collector.

1 Type.

$70536^{\circ}-$ Bull. $98-17-3$ 
Measurements of specimens of Hypurolepis javanica javanica.

\begin{tabular}{|c|c|c|c|c|c|c|c|c|}
\hline$\underset{\text { U.S.N.M. }}{\text { No. }}$ & Sex. & Locality. & Date. & Collector. & 远 & 䔍 & 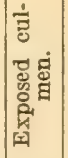 & 点 \\
\hline $218518 \ldots$ & Male.... & \multirow{2}{*}{ 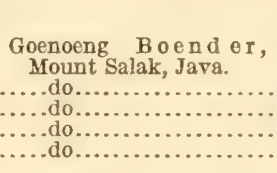 } & May 18,1909 & W. Palmer.... & 105 & $\begin{array}{l}m m \\
47\end{array}$ & $\begin{array}{c}m m \\
9\end{array}$ & $\begin{array}{l}m m . \\
10\end{array}$ \\
\hline $\begin{array}{l}218520 \ldots . \\
218519 \ldots \\
218522 \ldots \\
218521 \ldots\end{array}$ & $\begin{array}{l}\text { Male.... } \\
\text { Male.... } \\
\text { Female.. } \\
\text { Female.. }\end{array}$ & & $\begin{array}{lr}\text { May } & 15,1909 \\
\text { May } & 2,1909 \\
\text { May } & 3,1909 \\
\text { May } & 18,1909\end{array}$ & 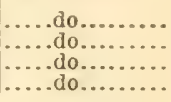 & $\begin{array}{l}97 \\
104 \\
101 \\
101\end{array}$ & $\begin{array}{l}42 \\
49 \\
42 \\
44.5\end{array}$ & \begin{tabular}{|l}
7 \\
9 \\
7.5 \\
8
\end{tabular} & $\begin{array}{l}10 \\
10 \\
9.3 \\
9.8\end{array}$ \\
\hline \multicolumn{3}{|c|}{ h verage of 5 specimens................. } & & & 101.6 & 44.9 & 8.1 & 9.8 \\
\hline
\end{tabular}

The present species is structurally different enough from Hirundo mustica Linnaeus, by reason of its broad bill, very short, slightly forked tail, to necessitate its generic segregation, as already claimed by Mr. Mathews. ${ }^{1}$ The proper generic name for it seems to be Hypurolcpis Gould ${ }^{2}$ (type, by subsequent designation, ${ }^{3}$ Hirundo domicola Jerdon [=Hirundo javanica domicola Jerdon]), since Herse Lesson ${ }^{4}$ is preoccupied by Herse Oken, 1815, for a genus of Lepidoptera. ${ }^{5}$ Mr. Mathews, in designating the type of Hypurolepis Gould, states it to be Hirundo domicola Jerdon "by monotypy" ; but Gould in his original institution of the genus in the text to plate 32 of his "Birds of Asia" specifically included Hirundo domicola Jerdon, Hirundo subfusca Gould [ = Hirundo tahitica Gmelin], and provisionally Hirundo neoxena Gould.

\section{Family LANIIDAE.}

\section{* LANIUS CRISTATUS Linnaeus.?}

[Lanius] cristatus Linnaeus, Syst. Nat., ed. 10, vol. 1, 1758, p. 93 (Bengal, India).

Recorded from the Anamba Islands by C. B. Kloss.?

\section{Family CAMPOPHAGIDAE.}

\section{ARTAMLES SUMATRENSIS CALOPOLIUS, new subspecies.}

Subspecific characters.- Similar to Artamides sumatrensis sumatrensis, from Sumatra, but larger, particularly the bill; female with upper surface and anterior lower parts somewhat paler; white bars on posterior lower parts broader, the black bars also somewhat so; black bars on rump and upper tail-coverts wider.

\footnotetext{
1 List Birds Australia, 1913, p. 163.

2 Birds Asia, vol. 1, April, 1868, text to pl. 32.

Mathews, List Birds Australia, 1913, p. 163.

"Rev. Zool, 1840, p. 145 (based on "Les Herses" of Lesson, Compl, Oeur. Buffon, rol, 8, 1837, p. 496).

\& Herse Oken, Lehrb. Naturg., vol. 3, 1815, pt. 1, p. 762.

- List Birds Australia, 1913, p. 163.

' Journ. Straits Branch Roy. Asiatic Soc., No. 41, January, 1904, p. 79.
} 
Description.-Type, adult female, No. 1710_n, T.S.N.M.; Pulo Mata, Anamba Islands, August 29, 1899 ; Dr. W. L. Abbott. Sides of head and neck, pileum, cerrix, back, and scapulars, slate gray; rump and upper tail-coverts varying from slate gray to gray No. $8{ }^{1}$ broadly and boldly barred with white and black, the white predominating on the shorter coverts; tail slate black, irregularly tipped with white; wings slate black, all the quills tipped, the secondaries broadly, the primaries narrowly, margined exteriorly with white, and all the remiges broadly edged interiorly on basal portion with white; lesser and median wing-coverts, with outer webs of tertials, gray, like the back; greater coverts slate gray, narrowly margined with whitish; primary coverts and alula slate color, narrowly edged and broadly tipned with white; chin, throat, and jugulum gray No. $6,{ }^{1}$ slightly and obsoletely barred imperfectly in places with paler gray; rest of lower surface white, boldly barred with black, these bars much narrower on the crissum; lining of wing white, narrowly barred with. black; "iris gray; bill black; feet dull black."

Ifeasurements of type.-Total length, $292.1 \mathrm{~mm}$.; wing, 160; tail, 112.5; exposed culmen, 26.5; tarsus, 27.

The female type above described is the only specimen obtained by Doctor Abbott. It is about the size of Artamides sumatrensis bungurensis (Hartert), ${ }^{2}$ from the Natuma Islands, but differs from the samesex of that race in the absence of ashy clouding on the posterior lower surface; the white and black bars being sharply contrasted, eren more so than in Artamides sumatrensis sumatrensis; white bars of lower surface apparently broader; and lower back, rump, and upper tail-corerts more sharply banded with black and white. This new race may be distinguished from Artamides sumatrensis difficilis (Hartert), ${ }^{3}$ from Balabac Island, Philippine Islands, by its larger size, and in the female by the wider white bars on the posterior lower surface.

Our single specimen of Artamides sumatrensis calopolius is apparently not fully adult, for the outer tail-feather's are tipped and subterminally mottled with dull white, and most of the primaries, all the secondaries, tertial", and primary coverts are broadly margined with white: while on the throat are seen some faint remmants of dark and light barring.

\section{Family MUSCICAPIDAE.}

CYORNIS BANYUMAS LAMPRA, new subspecies.

Subspecific characters. - Similar to Cyornis banyumas phitippinensis, but the male with upper parts of a lighter, brighter blue; anterior lower surface paler, more ochraccous (less tawny); posterior lower 
parts more whitish, the sides and flanks with much less ochraceous. Female very much paler, duller, and more grayish above than the same sex of Cyornis banyumas phitippinensis, with ochraceons of lower surface lighter, and that of lower breast, sides, and flanks much less extensive, the sides and flanks with rery little; lores dull gravish instead of white.

Description.-Type, adult male, No. 171095, U.S.N.M.; Pulo Jimaja, Anamba Islands, September 22, 18 - Dr. W. L. Abbott. Sides of head and neck, with entire upper parts (except forehead) rather light, grayish, indigo blue; forehead and short superciliary stripe azure blue; lores and nasal plumes black; remige: and rectrices grayish clove brown, all edged externally with the hlue of the mper parts; lesser and median wing-coverts colalt blue: remaining wingcoverts like the secondaric; chin and moustachial stripes deen blue black; throat, jugulum, and upper breast, ochraceons; re-t of lower surface white, laterally washed with ocharaceous; under wing-coverts buffy white, the feathers centrally fuscous, the elge of wing beneath fuscous mixed with whitish, buff, and hlue: axillars buff; " hill hlack, feet brownish lavender."

The male of this new race differs from the male of Cyornis banyumas banyzmas in somewhat lighter blue npler surface; in pure white median posterior lower part:, including the crisum: and very much less extenively ochraceous sides and flanks. The temale differs from that of Cyornis banyumes banyumas in the much mone bluish gray (instead of brownish gray) upjer surface, the tail externally blue instead of dull ferruginons; and in practically pure white instead of ochraceous abdomen and crisum. The male intergrades in color with Cyornis banyumas bunyumas through Cyornis banyumas phitippinensis and Cyomis banyumes mindoremsis Mearns; while the female is intermediate between Cyom is bompmos phatiphnemis and Cyomis banymmen banymmas, though nearer the former. A trinomial seems best to express this bird's relationships.

There is considerably more difference between the sexes in this form than in $C . b$. phitipunensis, the female heing relatirely as well as actually much paler and more grityish above. Tiro males (No: 171004 and 170961, U.S.N.M.) in part juvenal, part first autumn plumage, differ from the adults of the same sex in haring the throat and chin whiti-h, the tawny of breast more or le sumed with blachish, thi: chiefty in the form of scale-like fenther algings; miny of the superior wing-coverts and some of the tertials with broad apiral spots of ochracenus: and the feathers of head and hind-neck with broad shaft streaks or apical spots of tawny or ochraceous. Two

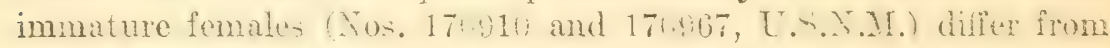
adult female: in their maler anterior bower parts and duller, nore brownish uner surface. There is comparatively little individul 
color differenee among the adult male: of this serie-, such as exists consisting chinfly of the dejth of the blue on the uprer larts, and the shade of the tawny on breast and throat.

Notes on the colors of the soft parts are given by Doctor Abbott on the labels, as follows:

Adult male, o. 171095, L.A.M. (type); Pulo .Tinaja: "bill black: feet brownish lavender."

Achlt male, So. 17tsizs, l'. X.M.; Pulo Kittan: "bill hack; feet Invender."

Adult male. No. 1710.) U, U.S.X.M.; Pulo Telaga: “bill black; iris dark brown."

Adult male, No. 171046, U.S.N.M.; Pulo Nanguan: "bill black; feet larender gray."

Adult male, No. 171005, U.S.N.M.; Pulo Mobur: "bill black."

Aduh female, No. 170911, T......M.: Pulo Piling: "bill black; feet pale purplish fleshy."

Adult female, No. 170960, U.S.N.M.; Pulo Siantan; "bill dark horn brown; iris dark brown."

Immature female, No. 170967, U.S.N.M.; Pulo Siantan: "bill black, brownish beneath."

Doctor Abbott further says that the species was fairly common in the forest on Pulo Mobur, August 24 to September 1, 1899; common in the forest on Pulo Jimaja, September 17-28, 1S99; and about Telok Arer Bini on Pulo Siantan, September 5-6, 1599 ; common also on Pulo Piling, August 17, 1899; and seen on Pulo Mata, August 24 to Scptember 1, 1S99; on Pulo Kelong, September 1, 1s99; and on Pulo Telaga, September 14-15, 1899.

Doctor Abbott obtained altogether 19 specimens of this new ('yornis, the detailed measurements of which are given herewith.

Measurements of specimens of Cyomis banyumas lampra.

\begin{tabular}{|c|c|c|c|c|c|c|c|c|c|}
\hline $\begin{array}{l}\text { U.S.N.M. } \\
\text { No. }\end{array}$ & Sex. & Locality. & Date. & Collector. & 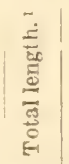 & $\sum_{\sum}^{\stackrel{20}{\equiv}}$ & تే & 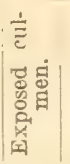 & 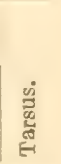 \\
\hline 170465 & Male... & Pulo Siantan, Anam- & Sept. 8,1899 & Dr. W. L. Abbott & $\begin{array}{c}m m \\
152.4\end{array}$ & $\begin{array}{c}m m \\
72.5\end{array}$ & $\begin{array}{c}m m \\
63\end{array}$ & $\sum_{12}^{m m}$ & $m_{17.5}$ \\
\hline $\begin{array}{l}170966 \\
170961 \\
170962 \\
370961 \\
271003\end{array}$ & $\begin{array}{l}\text { Mirale } \\
\text { Male... } \\
\text { Mdo .... } \\
\ldots \text { do }\end{array}$ & 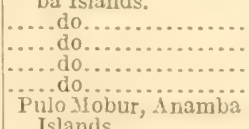 & $\begin{array}{l}\text { Aug. } 21,1899 \\
\text { Aug. } 22,1899 \\
\text { Aug. } 24,1899 \\
\text { Aug. } 25,1899\end{array}$ & 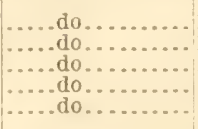 & $\begin{array}{l}152.4 \\
152.4 \\
158.8 \\
158.8 \\
158.8\end{array}$ & $\begin{array}{l}74 \\
73 \\
74.5 \\
76.5 \\
76.5\end{array}$ & $\begin{array}{l}61 \\
57 \\
63.5 \\
64 \\
64\end{array}$ & $\begin{array}{l}12.5 \\
12 \\
12.5 \\
12.5 \\
12\end{array}$ & $\begin{array}{l}18 \\
18.5 \\
18 \\
18.5 \\
18\end{array}$ \\
\hline $\begin{array}{l}171004 \\
171005 \\
171094\end{array}$ & $\begin{array}{l}\text { Mrale } 2 . . . \\
\text { Male.... } \\
\text {...do... }\end{array}$ & $\begin{array}{l}\text {...do................. } \\
\text { Pulo do Jimaja, Anamba } \\
\text { Islands. }\end{array}$ & $\begin{array}{l}\text { Aug. } 26,1899 \\
\text { Sept. } 21,1899\end{array}$ & 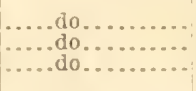 & $\begin{array}{l}152.4 \\
158.8 \\
158.8\end{array}$ & $\begin{array}{l}74.5 \\
72 \\
73.5\end{array}$ & $\left(\begin{array}{l}61 \\
63.5 \\
62\end{array}\right.$ & $\begin{array}{l}12 \\
11.5 \\
12.5\end{array}$ & $\begin{array}{l}18 \\
18 \\
18\end{array}$ \\
\hline $\begin{array}{l}171095 \\
171030\end{array}$ & $\begin{array}{l}\ldots \text { do } \ldots . . . \\
\ldots \text { do... }\end{array}$ & Pulo Kelong, 1 namba & $\begin{array}{l}\text { Sept. } 22,1899 \\
\text { A ug. } 30,1899\end{array}$ & ... do do........... & $\begin{array}{l}155.6 \\
158.8\end{array}$ & 74 & $\begin{array}{l}62 \\
62.5\end{array}$ & $\begin{array}{l}12.5 \\
12\end{array}$ & $\begin{array}{l}17 \\
17.5\end{array}$ \\
\hline 171046 & ...do... & $\begin{array}{l}\text { I'ulo Manguan, Anam- } \\
\text { ba Islands. }\end{array}$ & Sept. 1,1899 & ...do... & 152.4 & 75 & 62 & & 18 \\
\hline
\end{tabular}

${ }^{3}$ Measured in the flesh by the collector. 
Measurements of specimens of Cyornis banyumas lampra-Continued.

\begin{tabular}{|c|c|c|c|c|c|c|c|c|c|}
\hline $\begin{array}{l}\text { U.S.N.M. } \\
\text { No. }\end{array}$ & Sex. & Locality. & Dato. & Collector. & $\begin{array}{l}\vec{j} \\
\overrightarrow{0} \\
\overrightarrow{0} \\
\vec{\Phi} \\
\overrightarrow{0} \\
\overrightarrow{0}\end{array}$ & $\stackrel{30}{\Xi}$ & Еีं & 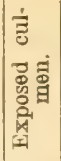 & 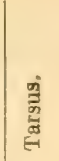 \\
\hline $171 S 25$ & Male.... & Pulo Rittan, Anamba & May 21,1900 & Dr. W. L. Abbott & $\mid \begin{array}{l}\mathrm{mm} . \\
155.6\end{array}$ & $m m$. & $\underset{60}{m m}$ & $\underset{13}{m m}$ & $\underset{13}{m m}$. \\
\hline 171059 & ...do... & Puio Telaga, Anamba & Sept. 14, 1899 & .....do. & 152.4 & 73.5 & 62 & 11.5 & 18 \\
\hline & verage of 14 & males..... & & & $|155.6|$ & 74.0 & 62.0 & 11.3 & 17.9 \\
\hline 170963 & [Female]. & Pulo Siantan, Inam- & Aug. 22,1899 & Dr. W. L. Abbott & 142.9 & 71 & 57.5 & 11.5 & 18 \\
\hline 170960 & Female. & .... do. & Aug. 21, 1899 & ..... do & 152.4 & 71.5 & 58 & 11.5 & 16.5 \\
\hline 170967 & Female? & .... do & Sept. 8, 1899 & .....do. . & 146.1 & 67.5 & 56 & 12 & 17 \\
\hline 170911 & Female.. & $\begin{array}{l}\text { Pulo Piling, Anamba } \\
\text { Islands. }\end{array}$ & Aug. 17,1899 & ......do.. & 155.6 & 73 & 59 & 12.5 & 17.5 \\
\hline 170910 & Female? & do & ....do. & ... do & 152.4 & 71 & 57 & 12 & 18 \\
\hline \multicolumn{5}{|c|}{ Average of 5 females. } & 149.9 & 70.8 & 57.5 & 11.9 & 17.4 \\
\hline
\end{tabular}

${ }_{1}^{1}$ Measured in the flesh by the collector.

${ }^{2}$ Immature.

\section{XANTHOPYGIA ZANTHOPYGIA (Hay).}

Muscicapa Zanthopygia HAY, Madras Journ. Lit. and Sci., vol. 13, pt. 2, "December, 1844" (1845), p. 162 (Malacca, Malay Peninsula).

One specimen, No. 170986, U.S.N.M, from Siantan Island, September 12, 1899. Length in flesh, $127 \mathrm{~mm}$.; "iris dark brown; feet blue; upper mandible dark horn brown, lower mandible pale plumbeous."

\section{HYPOTHYMIS AZUREA OPISTHOCYANEA Oberholser.}

Hypothymis azurea opisthocyanea OBerholser, Proc. U. S. Nat. MIus,, vol. 39, February 25, 1911, p. 602 (Pulo Piling, Anamba Islands).

Doctor Abbott obtained nine specimens-5 males, 4 females - of this recently described form from the Anamba Islands, collected August 18 to September 11, 1899, on Pulo Piling, Pulo Riabu, Pulo Manguan, and Pulo Siantan. Two of the three adult males from Pulo Siantan are rather less bluish on the posterior lower surface, particularly on the lower tail-coverts, than the other examples, but do not differ in size. There is some individual difference among all the males in the color of the upper parts, especially the pileum, this due largely to wear, as the tone of the bluo seems particularly liable to change from this cause. One bird from Pulo Manguan, taken, September 1, one from Pulo Riabu, August 18, and two from Pulo Siantan, August 24, are just completing the molt. Except for their larger size the females of this race are very close to those of Hypothymis azurea azurea, though the lower surface is usually more extensively shaded with blue. An immature male from Pulo Manguan, taken, August 31, is like the adult female, but has the secondary wing-coverts much more decply bluish. One of the females had the

${ }^{3}$ This is the original spelling of the specific name, as may be seen from the original citation. 
"bill black; feet dark leaden blue;" another female, possibly immature, had the "bill black above, bluish beneath."

Doctor Abbott writes that this species was fairly common on Pulo Siantan, August 19 to September 6, 1899; common on Pulo Jimaja, September 17-28, 1899; observed also on Pulo Piling, August 17, 1899 ; on Pulo Riabu, August 18, 1899; and on Pulo Telaga, September 14-15, 1899.

Detailed measurements of eight adults in the collection are as follows:

Measurements of specimens of Hypothymis azurea opisthocyanea.

\begin{tabular}{|c|c|c|c|c|c|c|c|c|c|}
\hline $\begin{array}{l}\text { U.S.N.M. } \\
\text { No. }\end{array}$ & Sex. & Locality. & Date. & Collector. & 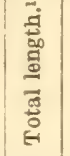 & 告 & సีं & 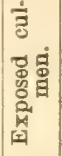 & 誊 \\
\hline $170957 \ldots$ & Male.... & Pulo Siantan, & Aug. 24, 1899 & Dr. W. L. Abbott. & $\begin{array}{c}\mathrm{mm} . \\
158.8\end{array}$ & $\begin{array}{l}m m \\
79\end{array}$ & $m m$. & ${ }_{11}^{m m}$ & ${ }_{17}^{m}$. \\
\hline $\begin{array}{l}170958 \ldots \\
170959 \ldots \\
171045 \ldots\end{array}$ & $\begin{array}{l}\ldots \text { do } \\
\ldots \text { do } \\
\ldots \text { do }\end{array} \ldots$ & Pulo M a nguan, & $\begin{array}{l}\text { Aug. - } 1899 \\
\text { Sept. 11, } 1899 \\
\text { Sept. 1, } 1899\end{array}$ & 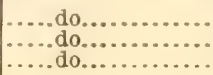 & $\begin{array}{l}168 \\
165.1 \\
\cdots\end{array}$ & $\begin{array}{l}76.5 \\
75.5 \\
77\end{array}$ & $\begin{array}{l}76 \\
78.5 \\
78\end{array}$ & $\begin{array}{l}10.5 \\
12 \\
11\end{array}$ & $\begin{array}{l}16 \\
16.5 \\
17.5\end{array}$ \\
\hline $170909 \ldots$ & $\ldots$ do.... & $\begin{array}{l}\text { Anamba Islands. } \\
\text { Pulo Piling, Anam- } \\
\text { ba Islands. }\end{array}$ & Aug. 17,1899 & ....do... & 175 & 80 & 76 & 10.5 & 18 \\
\hline $170920 \ldots$. & Female.. & Pulo Riabu, Anam- & Aug. 18, 1899 & $\ldots .$. do..... & 171.5 & 78 & 75 & 12 & 17 \\
\hline $\begin{array}{l}170922 \ldots \\
170921 \ldots\end{array}$ & $\begin{array}{l}\ldots \text { do }=. . . \\
\ldots \text { do } \ldots . . .\end{array}$ & 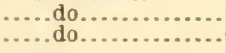 & $\begin{array}{l}\text {.....do...... } \\
\ldots \ldots \text { do.... }\end{array}$ & .....do............... & 171.5 & $\begin{array}{l}74.5 \\
77\end{array}$ & $\begin{array}{l}75 \\
78\end{array}$ & $\begin{array}{l}11.5 \\
11\end{array}$ & $\begin{array}{l}16 \\
16.5\end{array}$ \\
\hline
\end{tabular}

Together with the races recently described, the following forms of Hypothymis azurea seem now to be recognizable ${ }^{3}$ :

1. Hypothymis azurea azurea (Boddaert).-Philippine Islands, including Palawan and the Sulu group.

2. IIypothymis azurea styani (Hartlaub).-Island of Hainan.

3. Hypothymis azurea oberholseri Stresemann.-Formosa.

4. Hypothymis azurea coeruleocephala (Sykes). - India north to the Himalaya Mountains, and east to Cochin China.

5. Hypothymis azurea ceylonensis Sharpe.-Ceylon.

6. Hypothymis azurea prophata Oberholser.-Malay Peninsula to Sumatra, Java, and Borneo.

7. Hypothymis azurea forrestia Oberholser.-Mergui Archipelago.

8. Hypothymis azurea nicobarica Bianchi ${ }^{4}$ (=Hypothymis azurea calocara Oberholser).-Nicobar Islands excepting Car Nicobar.

9. Hypothymis azurea idiochroa Oberholser.-Car Nicobar Island, Nicobar Islands.

10. IIypothymis azurea tytleri (Beavan).-Andaman and Cocos Islands.

3 See Oberholser, Proc. U. S. Nat. Mus., vol. 39, 1911, pp. 593-615; Stresemann, Novit. Zool., vol. 20, 1913, pp. 293-297.

- Hypothymis azurea nicobarica Bianchi, Ann. Mus. Zool. Acad. Imp. Sci. do St. Pitersb., vol. 12, No. 1, June, 1907, p. 76 (Nicobar Islands). 
11. Hypothymis azurca opisthocyanea Oberholser.-Anamba and Tambelan Islands.

12. Hypothmis azurce gigantoptera Oberholser.-Natuna Islands.

13. IIypothymis azurea symmixta Stresemann.-Islands of Bali, Lombok, Sumbawa, Flores, and Alor.

14. Iypothymis azurea poncra Oberholser.--Batu Islands, western Sumatra.

15. Hypothymis azurea isocara Oberholser.-Banjak Islands, western Sumatra.

16. Hypothymis azlbea loucopthita ()beriolser.-Pagi lslands, western Sumatra.

17. Hypothymis azurea ametis Oberholser.-Nias Island.

18. IItpothemis azure consobrina Richmond.-Simalur Island, western Sumatra.

10. Hupothemis azurea richmenuli (iberholser.-Engano Island, western Sumatra.

\section{Family PYCNONOTIDAE.}

\section{AEGITHINA VTRIDISSIMA THAPSINA, new subspecies.}

Subspecific characters.-. - -imilar to Aegithina viridissima viridissima, from Sumatra, but much larger; oil green of upper surface, in the male, more rellowish; lower breast and abdomen paler, more rellowish.

Description.-Type, adult male, No. 170951, U.S.N.M.; Pulo Siantan, Anamba Islands, August 20, 1899; Dr. W. L. Abbott. Entire upper surface, excepting the upper tail-coverts, oil green, the rumpr comewhat yellowish; upper tail-corerts glos:y black; lores blackish; lengthened supra-orbital and suborbital snots rich lemon yellow; tail black, slightly tipped with oil green; wing-(quills blackish clore brown above, the tertials and outer webs of primaries and secondaries brownish black, the primaries, except the outer two, margined basally with oil green, the secondaries edged almost throughout with the same color, the tertials margined on outer webs with oil green, where marked distally with a conspicunus rellowish white spot, and on inner ranes lroadly bordored with citron yellow; all the upyer wing-coverts glossy black, the median series broadly tipned with white, the greater row more narrowly with rellowish white; inferior surface of remige. grarish clore brown, broadly edged on basal portion of inner webs with dull white; under wing-coverts inwardly white, barely washed with candry yellow, exteriorly, including the edge of wing, canary yellow: axillars canary yellow, basally somewhat whitjall : sides of hearl and neck, with chin, throat, and jugulum, oil green,

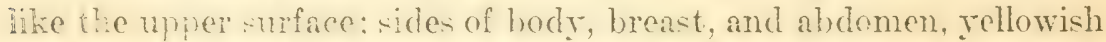
oil green, the middle fortion. together with the crisum, canary yellow: Aluke with a patch of elongated silky-white feuthers: thighs 
black. more or less orerlaid with canary rellow; "iris dark reddish brown; bill black ahore, leaden hencath : fect blue: claws black."

The female of this new form, compared with a female of Acgithina Tirulissima from Pulu Lankawi, wetern Malay Peninula, is very much more yellowish below.

Three specimens were obtained by Doctor Abbott, as follows:

Adult male (type), No. 170951, L.S.X.M.: Pulo Siantan, August 20. 1\$99. "Tris dark reddish brown; feet blue; rlaws black; bill black abore, leaden beneath."

Adult male, No. 170052 , U.S.N.M.; Pulo Siantan. August 21, 1899. "Feet blue leaden; bill black above, leaden beneath."

Lriul female, Yo. 170953, C.S.N.iI.: Pulo Siantan, September 5, 1899. "Feet blue; bill leaden blue, culmen and tip black."

The trpe has some of the wing-quills in process of molt, so that its true wing measurement is possibly somewhat greater than that given below. Doctor Abbott states that this species lived in the forest, and Tas tolerably comnen on Pulo siantan from August 19 to September 6, 1899.

Measurements of specimens of Aegithina viridissima thapsina.

\begin{tabular}{|c|c|c|c|c|c|c|c|c|c|}
\hline $\begin{array}{l}\text { U.S.N.M. } \\
\text { No. }\end{array}$ & Sex. & Locality. & Date. & Collector. & 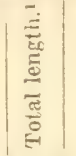 & $\dot{E}$ & $\dot{\vec{\sigma}}$ & 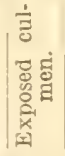 & 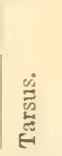 \\
\hline $170952 \ldots$ & Mrale... & Pulo Siantan, & Aug. 21,1899 & Dr. W. L. Abbott. & $\mid m m$. & $m m$. & $\left|\begin{array}{l}m m \\
47\end{array}\right|$ & $\mid \begin{array}{l}m m . \\
14.5\end{array}$ & $\begin{array}{l}m m . \\
18.5\end{array}$ \\
\hline $\begin{array}{l}170951 \ldots \\
170953 \ldots\end{array}$ & $\begin{array}{l}\text { Male ... } \\
\text { Female. }\end{array}$ & 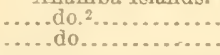 & $\begin{array}{l}\text { Aug. } 20,1899 \\
\text { Scpt. } 5,1899\end{array}$ & 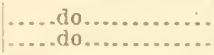 & $\begin{array}{l}140 \\
140\end{array}$ & $\begin{array}{l}64 \\
65\end{array}$ & $\left|\begin{array}{l}49.5 \\
50\end{array}\right|$ & $\mid \begin{array}{l}15 \\
15\end{array}$ & $\begin{array}{l}19 \\
19\end{array}$ \\
\hline
\end{tabular}

${ }^{1}$ Measured in the lesh by the collector.

2 Type.

PYCNONOTUS PLUMOSUS CHIrOPLETHIS, new subspecies.

suspecife charactres.-Similar to Pycnomotus 7 tumosus plumosus, from Singapore and the Malay Pcninsula, but much larger.

Description.-Type, adult male, No. 170941, U.S.N.M.; Pulo Siantan, Anamba Islands, August 24, 1899; Dr. W. L. Abbott. Upper parts olive brown, washed with olive green, least so on the pileum, the rump rather lighter and les graysh; wings and tail olive brown, the wing-quills, rectrices, and superior wing-coverts margined with olive grenen. mest hroadly on the secondaries and rectrices: sides of head and neck grayish hair brown, the shafts of auriculars grayish whitr: (hin and throat 'ream hufi: (rissum dull olivaceous gallstone yellow; rest of lower parts dull olive gray, lighter and inclining to huft medially: the middle of abdomen dull bufl lining of ring hufi. edge of wing greenish olive yollow; thighs 
brownish gray, tinged with olive yellow; "bill brownish black; feet dark fleshy brown."

Doctor Abbott obtained the following eight specimens:

Adult male, No. 170916, U.S.N.M.; Pulo Riabu, August 18, 1899.

Adult male, No. 170917, U.S.N.M.; Pulo Riabu, August 18, 1899.

"Iris brownish red; bill dark horn brown, paler beneath; feet fleshy brown."

Adult male, No. 171000, U.S.N.M.; Pulo Mobur, August 25, 1899. "Iris red; bill black; feet dark fleshy brown."

Adult male, No. 170938, U.S.N.M.; Pulo Siantan, August 20, 1899. "Feet fleshy brown."

Adult male, No. 170940, U.S.N.M.; Pulo Siantan, August 21, 1899.

Adult male (type), No. 170941, U.S.N.M.; Pulo Siantan, August 24, 1899. "Bill brownish black; feet dark fleshy brown."

Adult male, No. 170943, U.S.N.M.; Pulo Siantan, September 10, 1899.

Adult female, No. 170939, U.S.N.M.; Pulo Siantan, August 21, 1899.

There is comparatively little individual color variation in the series, such as there is consisting chiefly in the more deeply ochraceous tinge on the abdomen, and the more golden hue of the olive yellow crissum. The worn summer plumage is considerably paler than the freshly molted feathers.

In all but one bird the molt is more or less in evidence. In four (Nos. 170938, 170940, 170941, and 171000, U.S.N.M.), taken, August 20 to 25 , it is from about two-thirds to three-fourths completed; and many feathers of the old plumage remain; in one (No. 170943, U.S.N.M.), taken. September 10, it is ahout five-sixths advanced; in two others (Nos. 170916 and 170917), taken, August 18, it is, to external appearances, complete except for the wing-and tail-quills, but some of the contour feathers are still partly in their sheaths. One female ( $\mathrm{No} .170939)$, taken, August 21, has apparently not yet begun to molt.

Doctor Abbott says that this species was common in the scrubby jungle on Pulo Siantan. Measurements are as below: 
Measurements of Pycnonotus plumosus chiroplethis.

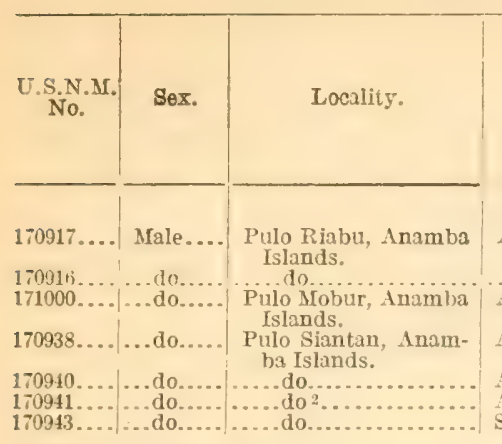

Average of 7 males.

\begin{tabular}{|c|c|c|c|c|c|c|c|}
\hline Date. & Collector. & 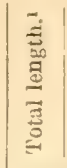 & $\stackrel{+\infty}{\Xi}$ & चี & 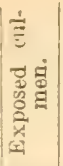 & 离 & 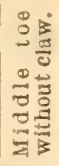 \\
\hline $\begin{array}{l}\text { Aug. } 18,1899 \\
\text { A...do. . . . } \\
\text { Aug. } 25,1899\end{array}$ & $\begin{array}{l}\text { Dr. W. L. } \\
\text { Abbott. } \\
\ldots \text { do........ } \\
\ldots \text { do ....... }\end{array}$ & $\begin{array}{l}m m . \\
196.9 \\
222.3 \\
203.2\end{array}$ & $\begin{array}{l}m m . \\
85 \\
86.5 \\
86\end{array}$ & $\begin{array}{l}m m . \\
79 \\
79 \\
80\end{array}$ & $\begin{array}{l}m m . \\
15 \\
14.9 \\
14.5\end{array}$ & \begin{tabular}{|l|}
$m m$. \\
20.3 \\
21 \\
21
\end{tabular} \mid & $\begin{array}{l}m m \\
13.8 \\
11 \\
13.5\end{array}$ \\
\hline Aug, 20, 1899 & ...do..... & 196.9 & 88 & 78 & 15.5 & 20.5 & 14 \\
\hline $\begin{array}{l}\text { Aug. } 21,1899 \\
\text { Aug. } 24,1899 \\
\text { Sept. 10, } 1899\end{array}$ & $\begin{array}{l}\ldots \text { do } \\
\ldots \text { do....... } \\
\ldots \text { do..... }\end{array}$ & $\begin{array}{l}203.2 \\
\ldots . .\end{array}$ & $\begin{array}{l}89 \\
90.5 \\
89.5\end{array}$ & $\begin{array}{l}77 \\
80 \\
81\end{array}$ & $\begin{array}{l}15.3 \\
15.5 \\
16\end{array}$ & \begin{tabular}{|l|}
21 \\
20 \\
20.8
\end{tabular} & $\begin{array}{l}14 \\
14 \\
14.2\end{array}$ \\
\hline & & 204.5 & 87.8 & 79 & 15.2 & 20.7 & 13.9 \\
\hline Aug. 21, 1899 & $\begin{array}{l}\text { Dr. W. L. } \\
\text { Abbott. }\end{array}$ & 200 & 83.5 & 75 & 15 & 20.5 & 13.8 \\
\hline
\end{tabular}

${ }_{2}$ Measured in the flesh by the collector.
2 Type.

PYCNONOTUS SIMPLEX HALIzONUS, new subspecies.

Subspecific characters.-Like Pycnonotus simplex olviaceus, from the Malay Peninsulat, but decidedly lirger; lower parts lighter, brighter, and less tinged with brownish (more grayish).

Description.-Type, adult female, No. 171080, 'T.S.X.M.: Pulo Jimaja, Anamba Islands, September 22, 1899; Dr. W. L. Abbott. Upper surface dark olive brown, with a slight tinge of greenish, the upper tail-coverts sepia; wings and tail between clove brown and sepia, the wing-quills and their upper coverts edged externally with sepia; sides of head, together with neck and breast, olive brown, the shafts of auriculars a little paler; lower surface pale yellowish white, the sides and flanks light olive brown, the breast and jugulum hear vily washed with the same color; lining of wing yellowish white: thighs light olive brown tinged with yellow; "iris white; bill horn brown, pale beneath at base; feet fleshy brown."

This new race differs from Pycnonotus simplex simplex from silmatra, in larger size, darker lower parts, and paler, more wreenish upper surface. The following five specimens were obtained by Doctor Abbott:

Adult male, No. 170944, U.S.X.M.; Pulo Siantin, September 9, 1899.

Adult male, No. 171078, L.S.N.M.; Pulo Jimaja. Septemberp 20 , 1899. "Iris gray; feet fleshy brown."

Adult female, No. 171077, L.S.N.M.; Pulo Jimaja, September 1:4, 1899. "Iris white; feet fleshy brown."

Adult female, No. 171076, U.S.N.M.; Pulo Jimaja, S'ptembir 19, 1899. "Iris white; bill horn brown, palex" at bilse beneath: facts fleshy brown." 
Adult female (trpei, No. 171080 , L.S.N.M.; Pulo Jimaja, September 22,1899 .

The iris, it will be noticed, is white or gray. All fire specimens slew more or less eridences of the nearly completed molt, but on these collected on September 19 and 22 only slight triecs remain.

Iressurements of the scries of F'yenonotus simptex hatizonus are given below:

Measurements of specimens of Pycnonotus simplex halizonus.

\begin{tabular}{|c|c|c|c|c|c|c|c|c|c|c|}
\hline $\begin{array}{l}\text { U.S.N.M. } \\
\text { No. }\end{array}$ & Sex. & Locality. & Date. & Collector. & 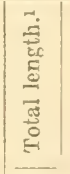 & 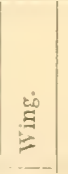 & Еี & 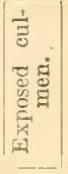 & 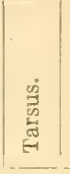 & 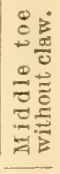 \\
\hline $170944 \ldots$ & Male.... & \multirow{2}{*}{$\begin{array}{l}\text { Pulo Siantan, Anam- } \\
\text { ba Islands. } \\
\text { Pulo Jimaja, A namba } \\
\text { Islands. }\end{array}$} & Sept. 9, 1899 & \multirow{3}{*}{$\begin{array}{l}\text { Dr. W. L. } \\
\text { Abbott. } \\
\ldots \text { do ....... }\end{array}$} & $m m$. & $\left|\begin{array}{l}m m . \\
\cdots \cdots\end{array}\right|$ & $\begin{array}{c}m m \\
73\end{array}$ & $\begin{array}{c}m m \\
13\end{array} \mid$ & $\left|\begin{array}{c}m m \\
18\end{array}\right|$ & $\begin{array}{l}m m . \\
11.5\end{array}$ \\
\hline $171078 \ldots$ & ...do..... & & Sept. 20,1899 & & 190.5 & 84 & 76 & 13.2 & 18.5 & 13. \\
\hline \multicolumn{4}{|c|}{ Arerage of two males. } & & 190.5 & 84 & 74.5 & 13.1 & 18.3 & 12.5 \\
\hline $171076 \ldots$ & Female.. & $\begin{array}{l}\text { Pulo Jimaja, Anamba } \\
\text { Islands. }\end{array}$ & Sept. 19,1899 & \multirow{3}{*}{$\begin{array}{l}\text { Dr. W. L. } \\
\text { Abluott. } \\
\ldots \text { do ............. }\end{array}$} & 187.3 & 84 & 76.5 & 12.1 & 18.5 & 11 \\
\hline $\begin{array}{l}171077 \ldots . . \\
171080 \ldots .\end{array}$ & $\begin{array}{l}\ldots \text { do } \ldots . . . \\
\ldots \text { do }\end{array}$ & 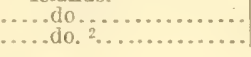 & Sent. 22,1899 & & $\begin{array}{l}187.3 \\
181\end{array}$ & $\mid \begin{array}{l}84 \\
82,5\end{array}$ & 76.5 & $\left|\begin{array}{l}12.2 \\
12.8\end{array}\right|$ & $\begin{array}{l}18.2 \\
18\end{array}$ & $\begin{array}{l}11.8 \\
11.5\end{array}$ \\
\hline \multicolumn{3}{|c|}{ A rerage of three } & & & 185.2 & 83.5 & 76.3 & 12.4 & $18.2^{\prime}$ & 11.4 \\
\hline
\end{tabular}

There are evidently two distinct species at present confused under the name Pycnonotus simplex. One of these is a large bird, in color much resembling Pycuenotus plunosie, with rather yellowish brown upper parts: distinctly sealy crown feathers; hrownish and buffy lower surface, particularly the crissum; and red or orange iris; to which the name I'yenonotus limuneus of BIyth," despite the briefness of the acompanying description, undoubtedy applies. The other species, which occupies nearly the same geographic range, is of swaller size; his no sealy apjearanee on the feathers of the crown; has a darker, more greenish olire brown upper surface; lower parts with the dark weas grarish rather than buffy, hown: the light areas, especiully the crissum and thout, whitish, with yollowish instead of brownish and buffy suffusion; iris white or grayish; and in general coloration is almost identical with Iole olvecen. This bird is Picnonotus simptex Lesson. ${ }^{4}$ Dr. C. TT. Richmond has recently identified ${ }^{5}$ Picnonotus simplex Lesson with the lirge, brownish and buffy, redeyed species: and following him the present writer deseribed the Sumatra race of the white-cyed bird as Pycnonotus olivaceus chloeodis. After much further study of these birds I am now conrinced, how-

: Journ. Asiatic Soc. Bengal, rol. 14, pt. 2, No. 164, Vecember, 1845, p. 568 (Malacca, Malay Peninsula).

'Fer. Zool., rol. 2, June, 1839, p. 167 (Sumatra).

1. Proc. U. S. Nat. Mus., vol. 26, Feb. 4, 1993, pp. 506-507.

( Smiths. Misc. Coll., vol. G0, No. 7, Oct. 20, 1912, p. 11. 
ever, that Pycnonotus simplex of Lesson is the white-eyed species, and that consequently my Pycnonotus olivaceus chluendis is a synonym. Lesson's original description ${ }^{1}$ reads as follows: "Corpore suprà trriseoluteolâ, albo luteo tincto infrà ; rostro corneo; pedibus bruneis." The really distinctive portion of this diagnosis is the cxpression "albo luteo tincto infrà," which could not apply to the red-eyed bird, but is very well descriptive of the white-eyed specits, is is at one evident on comparison of both with this description. The expression "corpore supra griseo-luteolâ" also agrees better with the white-ered than with the red-eyed species, for the latter is decidedly brown above.

Of Pycnonotus simplex at leist three subspecies are recognizahle. The synonymy and geographic ranges of these are as follows:

1. Pycnonotus simplex simplex Lesson.

Picnonotus simplex Lesson, Rev. Zool, vol. 2, June, 1839, p. 167 (Sumatra).

Pycnonotus olivaceus chloeodis OBerholser, Smiths. Misc. Coll., vol. 60, No. 7, October 26, 1912, p. 11 (Tapanuli Bay, northwestern Sumatra).

(reographic distribution. Sumatrib. Bomeo, and some of the adjibcent islands.

2. Pycnonotus simplex otivaceus (Moore).

Microtarsus olivaceus Moore, in Ilorsfield and Moore, Cat. Birds Mus. East Ind. Co., vol. 1, 1854, p. 249 (Malacca).

Geographic distribution.-Malay Peninsula.

3. Pycnonotus simplex hatizonus Oberholser.

Pycnonotus olivaceus halizonus OBerHolser, Bull. U. S. Nat. Mus,, No. 98, 1917, p. 43 (Pulo Jimaja, Anamba Islands).

Geographic distribution.-Anamba Islands.

PYCNONOTUS BRUNNEUS ZAPOLIUS, new subspecies.

S'ubspecific characters. - Similar to Pycnonoins brunneus brunneus, from the Nalay Peninsula, but larger; upper surface larker; lower parts lighter, more grayish, the dark areas less brownish, the light areas more clearly yellowish, less ochraccous.

Description.-Type, adult male, No. 170942, U.S.N.M.; Pulo Siantan, September 5, 1899; Dr. W. L. Abbott. Pileum between

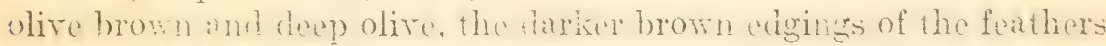

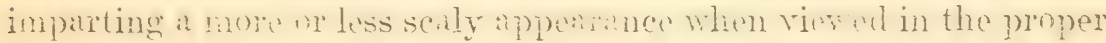
light: cervir, back, and scapulats deep olive with a slight olive brown -tinge, the (lingedy concealed centers of the feathers clore brown; rump and shorter upper tail-coverts dark bufy brown; longest upper tail-coreris olive brown: vings and tail smmerhat olivaceous clore brown, but the lesser wing-coverts of the same color as the beck, though slightly poller, the whuining supering wing-coverts and the 
wing-quills edged, and the corerts and tertials also tipped, with the deep olive of the back; sides of head and neck like the pileum but with less squamate appearance; chin and upper throat soiled cream color with a slight olire buff tinge; median portion of abdomen and breast marcuerite yellow; thighs, flanks, sides of breast and of body, buffy olire, somewhat paler posteriorly and shading into the pale yellow of the middle of abdomen; jugulum and breast paler buffy olire, mixed with light yellowish; crissum dull cream buff, the centers of the feathers light buffy olive; lining of wing cream buff, the outer edge chamois; "iris red; bill dull black, horn brown at base beneath; feet fleshy brown."

Jieasurements of t!lpe.-Total length (in flesh), $190.5 \mathrm{~mm}$.; wing, 90 ; tail, 75 ; exposed culmen, 14 ; tarsus, 19 ; middle toe without claw, 13.5 .

Although this new race of Pycnonotus brunneus is here described from a single specimen, it must be regarded without doubt as distinct. The type has been carefully compared with all of our large series of this species, from rarious parts of its range, and can not be matched by any other cxample. 'This is, so far as the upper parts are concerned, one of the darkest and most greenish of the races of Pycnonotus brunncus; while bclow it is more grayish and more clearly yellow than any of the others. Thus it superficially rery much resembles some of the forms of Pycnonotus simplex, but it is readily distinguished from all of these by its dark buffy crissum, red eyes, squamate pileum, and other characters.

The type is in fresh plumage, but still shows evidences of molt among the contour feathers, rectrices, and remiges. Its proper wing length may therefore be eren somewhat longer than above given.

Doctor Abbott reports this species as common on Pulo Siantan at the time of his risit, but this may refer in part at least to Pycnonotus simpex halizonus, since at that time no one separated these two species.

The following races of Pycnonotus brunneus are now recognizable:

1. Pycnonotus brunneus brunneus Blyth.

[Pycnonotus] brunneus Blytr, Journ. Asiatic Soc. Bengal, vol. 14, pt. 2, No. 164, December, 1845 , p. 568 (in text) (Malacca, Malay Peninsula).

Brachypus modestus Blytu, Journ. Asiatic Soc. Bengal, vol. 14, pt. 2, No. 164, December, 1845, p. 568, footnote (new name for Pycnonotus brunneus Blyth) (A. Hay MS.).

Greograptic distribution.-Malay Peninsula, Sumatra, Borneo, and neighboring islands.

2. Pycnonotus brunneus zapolius Oberholser.

Pycnonotus brunneus zapolius OBerhoLser, Bull. U. S. Nat. Mus., No. 98, 1917, p. 45 .

Geographic distribution.-Anamba Islands. 
3. Pycnonotus brunneus prillwitzi Hartert.

Pycnonotus prillwiti Hartert, Novit. Zool, vol. 9, Decemier 16, 1902, p. 561 (Karangbolong, southern Java).

Geographic distribution.-Java.

\section{Family TIMALIIDAE. \\ HORIZILLAS MAGNIROSTRIS (MoOre).}

Alcippe mannirostris Monne, Proc. Zool. Soc. Lond., 1854 (May 8, 1855), p. 277 (Malacca, Malay Peninsula).

Nine specimens are in the collection, as follows:

Male, No. 171024, U.S.N.M.; Pulo Mata, August 29, 1899. Length, $178 \mathrm{~mm}$. "Bill dark horn brown abore, horny yellow beneath."

Female, No. 170946, U.S.N.M.; Pulo Siantan, September 6, 1899. Length, $165 \mathrm{mmm}$. "Iris pink; feet pale leaden; upper mandible dark horn brown; lower mandible leaden. Shot in heavy forest." 1

Male, No. 170945, U.S.N.M.; Pulo Siantan, September 6, 1899. Length, $178 \mathrm{~mm}$. "Feet pale leaden blue; upper mandible horn brown; lower mandible leaden."

Male, No. 171083, U.S.N.M.; Pulo Jimaja, September 21, 1899. Length, $184.5 \mathrm{~mm}$. "Iris red; feet slaty blue, soles yellow.

Male, No. 171087, U.S.N.M.; Pulo Jimaja, September 22, 1899. Length, $171.5 \mathrm{~mm}$. "Feet fleshy white; iris gray brown; upper mandible horn brown; lower mandible yellow."

Sex unknown, No. 1710s8, U.S.N.M.; Pulo Jimaja, September 22, 1899. Length, $181 \mathrm{~mm}$. "Iris red; feet larender blue; upper mandible dark horn brown; lower mandible leaden."

Male, No. 171084, U.S.N.M.; Pulo Jimaja, September 24, 1899. Length, $178 \mathrm{~mm}$.

Male, No. 171086, U.S.N.M.; Pulo Jimaja, September 24, 1899. Length, $178 \mathrm{~mm}$.

Male, No. 171085, U.S.N.M.; Pulo Jimaja, September 26, 1899. Length, $178 \mathrm{~mm}$. "Iris red; feet slaty blue; tarsi brownish; upper" mandible dark horn brown; lower mandible leaden.'

All these birds are more or less in process of molt. The streaking on the jugulum is almost obsolete in some, strongly marked in others. The color of the back and scapulars varies from a grayish olive brown to a decidedly rufescent olive brown. There is apparantly no difference of consequence in either size or color between this series from the Anamba Islands and a larger series from the Malay Peninsula.

Doctor Abbott found this bird common on Pulo Jimaja from September 17 to 28,1899 . 
This species is clearly ont of place in the genus Turdinus, to which Doctor. Sharpe has referred it, ${ }^{1}$ but is strictly congeneric with Horizilla. magna, the type of IIorizilles. The present generic name for this group is Horizillas Oberholsex," the employment of which in riace of Malacopteron Eyton ${ }^{3}$ we have elsewhere explained. ${ }^{4}$

\section{ANUROPSIS MALACCENSIS MALACCENSIS (Harllaub).}

Brachypteryx malaccensis IIartudu, Rev. Zool., 1814, p. 402 (Malacca, Maliy Peninsula).

Three specimens are in the collection, as follows:

Adult male, No. 171 \$, L.S.X.M.: Pvlo Jimaja, Ceptember 21 , 1899. "Iris dark red; feet pale brownish fleshy."

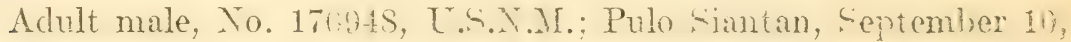
1899 .

Adult female, No. 170917, U.S.N.M.; Pulo Siantan, August 24, 1899.

They average a very litte darker on moner wats, sides, and flanks than typical examples of the stecies from the Nalay Peninsula; but in the absence of any othei characters, the-e differences anpear too slight and ineonstant to be of subsivecifie immortance. Ill these examples show traces of a nearly completed molt: but the bird taken

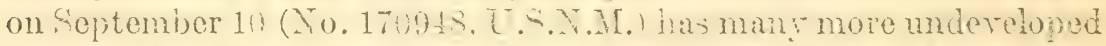
feathers than the others, particularly on pilenm, thront, breast, and tail.

Measurements are given below.

Measurements of specimens of Anuropsis malaccensis malaccensis.

\begin{tabular}{|c|c|c|c|c|c|c|c|c|c|}
\hline $\begin{array}{l}\text { U.S.N.M. } \\
\text { No. }\end{array}$ & Sex. & Locality. & Date. & Collector. & 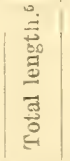 & $\stackrel{\infty}{\nexists j}$ & 忢 & 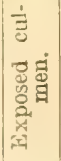 & $\underset{\frac{\pi}{\sigma / 2}}{\vec{\pi}}$ \\
\hline $170948 \ldots$ & Male.... & Pulo Siantan, Anamba & Sept. 10,1599 & Dr. W. L. Ab- & $\left|\begin{array}{l}m m \cdot \\
136.5\end{array}\right|$ & $\begin{array}{c}m m \\
68\end{array}$ & $\begin{array}{c}m m \\
30\end{array}$ & $\begin{array}{c}m m \\
16\end{array}$ & $\begin{array}{l}m m \\
28.5\end{array}$ \\
\hline $171081 \ldots$ & Male.... & Pulo Jimaja, Anamba & Sept. 21, 1899 & .....do.......... & & 67.5 & 35 & 16.5 & 29 \\
\hline $170947 \ldots$ & Female.. & $\begin{array}{l}\text { Pulo Siantan, Anamba } \\
\text { Islands. }\end{array}$ & Aug. 2!, 1599 & .....do... & 139.7 & 63.5 & 33 & 15 & 28 \\
\hline
\end{tabular}

1 Cat. Birds Brit. Mrus., vol. 7, 1883, p. 517 .

3 Horizillas Oberholser, Smiths. Misc. Coll., Quart. Issue, vol. 48, 3 [ay 13, 1905, p. 65.

3 Malacopteron Eyton, Proc. Zool. Soc. Lond., 1539, p. 102 (type, Mfulacopteron magnum Eyton;

4 Smiths. Misc. Coll., Quart. Issue, vol. 48, May 13, 1905, po. 6t-65.

5 Measured in the flesh by the collector. 
MIXORNIS PILEATA ZOPHERA, new subspecies.

Subspecific characters. - Similar to . Wixornis pilente pileate Blyth, from the Malay Peninsula, but averaging larger; un mer surface darker, more rufescent, the chestnut of pileum more extendet posteriorly; lower parts paler; streaks on throat and jugulum much heavier.

Description.-Type, adult male, No. 171062, U.S.N.II.; Pulo Telaga, Anamba Islands; September 14, 1899; Dr. W. L. Abbott. Pileum reddish chestmut (between chestnut and burnt sienna), the forchead mixed with grayish; superciliary stripe and sides of head and neck olive buff, with obscure streaks of dusky, the aurieulars shading posteriorly into ligint reddish chestnut; rest of upper parts raw umber; middle tail-feathers and outer vanes of others, except two outermost pairs, chestnut, the tips and obsolescent bars which extend faintly orer all the feathers almost to their bases, sepia, the rest of tail dark rufescent hair brown with numerous almost obsolete darker bars, the inner webs narrowly nargined with pale brownish on their basal portions; primaries and secondaries dark hair brown, basally margined on inner wobs with cream white, on outer webs with chestnut, except outermost primaries, which are edged with pale brownish; tertials chestnut; superior wing-coverts burnt sienna; edge of wing sulphur Tellow: throat, jugulum, breast, and middle of abdomen sulphur yellow, the throat and jugulum hearily streaked with black: sides, flanks, and crissum, olive buff; lining of wing pale sulphur yellow; "iris reddish brown: bill dark horn brown, dark leaden beneath; feet pale brownish green."

This new form, in its pale, heavily streaked lower parts and large size, resembles MFixornis pileata everetti of the Natuna Islands, but differs from that bird in its lighter, much less rufescent (more grayish) upper surface (the back thus more contrasted with pileum), and in the somewhat heavier streaking of the anterior lower parts.

Eleven specimens were obtained, as follows:

Adult male, No. 170915, U.S.N.M.: Pulo Riabu, August 18, 1899.

Adult male, To. 170949, U.S.X.M.; Pulo Siantan, September 6, 1899. "Iris gray brown; feet brownish olive; upper mandible horn brown; lower mandible leaden : naked orbital skin blue."

Adult male, No. 170950, U.S.N.ML.; Pulo Siantan, September 11, 1899. "Iris dark brown; lores blue."

Adult male (type), No. 171062, L.S.N.M.; Pulo Telaga, September 14,1899 .

Adult male, No. 171065, U.S.N.M.: Pulo Tolaga, September 15, 1899. "Tris ochrous brown."

2 The name in common use for this species is Mixornis gularis, which is the Motacilla gularis of Rafles (Trans. Linn. Soc. Lond., vol. 13, 1822, p. 312); but this is preoccupied by Iotacilla gularis Gmelin (Syst, Nat., vol. 1, pt. 2, 1789, p. 997), and therefore untenable. The proper name seems to bo Prinis pileata Bigth (Journ. Asiat. Soc. Bengal, vol. 11, 1812, p. 201). This species should consequently stand as Mixornis pileata (Blyth). (Sce Oberholser, Smiths. Misc. Coll., vol. 60, No. 7, Oct. 20, 1912, p. 9).

$70536^{\circ}-$ Bull. $98-17-1$ 
Adult male, No. 171082, U.S.N.M.; Pulo Jimaja, September 21, 1899. "Iris dark brown; feet brownish green."

Adult female, No. 170914, U.S.N.M.; Pulo Riabu, August 17, 1899.

Adult female, No. 174796, U.S.N.M.; Pulo Riabu, August 23, 1900. "Iris pale yellowish gray; naked skin about eye dull blue."

Adult female, No. 171064, U.S.N.M.; Pulo Telaga, September 14, 1899. "Iris ochrous brown; upper mandible dark leaden; lower mandible leaden; feet pale brownish green."

Adult female, No. 171063, U.S.N.M.; Pulo Telaga, September 14, 1899. "Iris dark brown."

Adult female, No. 171066, U.S.N.M.; Pulo Telaga, September 15, 1899.

The above series is very uniform in color, notwithstanding considerable individual difference in the width of the streaks on the throat, and the degree of rufescence on the back. The female is in size identical with the male, but is noticeably less rufescent on the upper surface, excepting, of course, the pileum. All these specimens excepting the type, taken from August 15 to September 15, show evidences of molt in progress. Doctor Abbott writes that this was a common species on Pulo Riabu, August 18, 1899; on Pulo Jimaja, September 17-28, 1899; common in thickets on Pulo Siantan, August 19 to September 6, 1899; and that it was the commonest bird of any kind on Pulo Telaga, September 14-15, 1899.

Measurements of the entire series are given below.

Measurements of specimens of Mixornis pileata zophera.

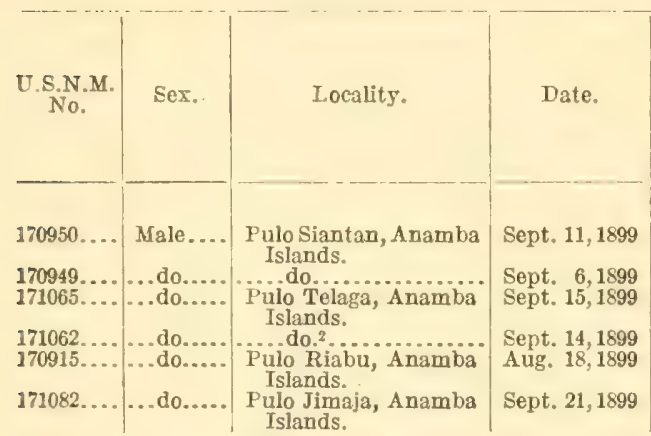

A rerage of 6 males.

\begin{tabular}{|c|c|c|c|c|c|}
\hline Collector. & 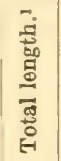 & $\stackrel{\Xi}{\Xi}$ & : & 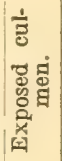 & 总 \\
\hline \multirow{2}{*}{ 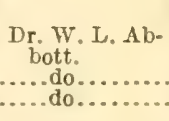 } & $m m$ & $\begin{array}{c}m m \\
60\end{array}$ & $\frac{m m}{53}$. & $\mid \begin{array}{c}m m \\
13.5\end{array}$ & $\frac{m m}{18}$. \\
\hline & \begin{tabular}{|l|}
146.1 \\
136.6
\end{tabular} & $\begin{array}{l}61 \\
61.5\end{array}$ & $\begin{array}{l}51 \\
53.5\end{array}$ & $\begin{array}{l}14.5 \\
13.5\end{array}$ & $\begin{array}{l}20 \\
18\end{array}$ \\
\hline \multirow[t]{2}{*}{..... do do .............. } & $\begin{array}{l}152.4 \\
146.1\end{array}$ & \begin{tabular}{|l|}
62.5 \\
63.5
\end{tabular} & $\begin{array}{l}55 \\
59\end{array}$ & $\begin{array}{l}13 \\
15\end{array}$ & $\begin{array}{l}19.5 \\
20.5\end{array}$ \\
\hline & $\ldots$ & 62 & 55 & 14 & 20 \\
\hline \multirow{4}{*}{ 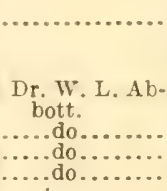 } & 145.3 & 61.8 & 54.4 & 13.9 & 19.3 \\
\hline & 146.1 & 62 & 56 & 13.5 & 19 \\
\hline & 136.6 & $\begin{array}{l}58.5 \\
60.5\end{array}$ & $\begin{array}{c}51.5 \\
349\end{array}$ & $\begin{array}{l}13 \\
12.5\end{array}$ & \begin{tabular}{|l|}
17.5 \\
19.5
\end{tabular} \\
\hline & 146.1 & 65 & 61 & 14 & \\
\hline \multirow[t]{2}{*}{.....do........... } & 149.4 & 61.5 & 56 & 14.5 & 20 \\
\hline & 144.6 & 61.5 & 54.7 & 13.5 & 19.2 \\
\hline
\end{tabular}




\section{Family TURDIDAE.}

\section{Tittacincla malabarica ochroptila, new subspecies.}

Subspecific characters.--Similar to Kittacincla malabarica ${ }^{1}$ from the Malar Peninsula, but larger; male with the deep tawny color of posterior lower parts much lighter; metallic sheen of upper parts less purplish; female with slate color of upper surface and breast lighter, and rufous of posterior lower parts more uniform.

Drecription.-Type, adult male, No. 170954, U.S.N.M.; Pulo Siantan, Anamba Islands, September 8, 1899; Dr. W. L. Abbott. Whole head, neck, jugulum, back, scapulars, lesser and median wingcoverts, glossy blue black; rump and upper tail-coverts pure white; wing-quills, prinary and greater corerts, clove brown, with a bluish black sheen on exposed upper surface; tail brownish black with a slight bluish sheen, the outer four pairs of feathers with broad white tips: whole of posterior lower surface and lining of wing deep tawny, the latter somewhat mixed with white.

Geograptic distribution.--The Anamba Islands, except the southern islands of Pulo Riabu and Pulo Piling.

The male of this new race differs from that of Kittacincla malabarica suavis, of Borneo, most conspicuously in having broad dark brown bases to the outer tail-feathers; the throat, breast, and upper surface are not so deeply black, but somewhat more glossy. The female is very different from the male, and is likewise in striking contrast to the female of Kittacincla malabarica suavis, for the entire upper surface is slate color, not black; the wings and tail are lighter, and more brownish or slaty; upper wing-coverts with some tawny edgings; throat and breast slate color instead of black; rufous of posterior lower parts lighter; outer tail-feathers with brown bases.

Of this new form Doctor Abbott obtained seren specimens, as follows:

Adult male (type), No. 17(9954, U.S.N.M.; Pulo Siantan, September $8,1899$.

Adult male, No. 170956, T.S.X.M.; Pulo Siantan, September 10, 1899 .

Adult male, No. 171(14:3, T.S.X.M.; Pulo Nanguan, September 1, 1899.

Adult male, No. 171075, T.S.N.M.; Pulo Jimaja, September 23, 1899.

Immature male, No. 171042, T.S.Y.M.; Pulo Manguan, September 1, 1899 .

Adult female, To. 17(195.5, L.S.X.M.; Pulo Siantan, September S, 1899.

I For the use of the specific name malabarica scorali in ylace of wecroura Gmelin, see Richmond, Proc. U. S. Nat. Mus., rol. 26, 1903, p. 512. 
Immature female, Yo. 1710-11, T.S.....I.; Pulo Manguan, Augunt 31, 1899. Length, $203 \mathrm{~mm}$.

All the adult birks are in proce-s of molt, involving chiefly the wing and tail feathers, though the type (No. 170954, U.S.N.M.) has the feather's of most of the chin and forepart of the lead in their sheaths, ant all the other specimens have some molting feather's on the body.

The adult female differs from the adult male in her shorter tail; smaller general -iza' dull, nommetallie, bluish slate-colored umer parts, throat, and breast, the pileum with a hrowni-h tinge: duller, more brownish wings and tail; tawny edgings on some of the upper wing-coverts; and lighter shade of the posterior lower parts, the thighs and middle of abdomen particularly paler.

The immature male (No. 171042, U.S.N.M.) obtained by Doctor Abbott is in process of molt, and is changing from the jurena! into the completely adult plumage. It differs from the adult male in partly brown heat and back, the black featler: of the adult plimage having only partly replaced those of the jurenal dress; short, more brownisis tail: much more brownish wing:, tle remige edged partly on exterior webs with tawny, the greater and median wing-corerts broadly tipped with the same (the lesser coverts have assumed the black of atult flumage): sides of head and of neck dull dark bromn,

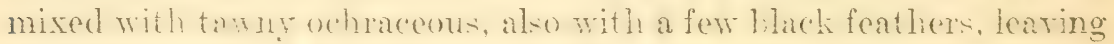

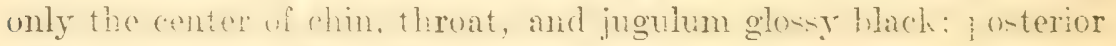
lower parts of a paler rufous.

The inmature female (No. 171041, U.S.N.M.) is in what appears to be jurenal ? lnmage, and differs from the adult female in having the upper surface lighter, decidedly more brownish, the pileum, back, and s(apulars being particularly brown: the rtimp with an anterior band of tawny, and all the white washed with tawny: tail more brownish, all the white tips, excepting those of the two outer pairs, much mottled with brown; wings more brownish; remiges broadly edged on mater webs with dull tawny: median wing-covert: more conspicuously tipped with tawny ochraceous; lesser wingcoverts with a broad white streak along the shaft or on the outer web of each feather; forehead, lores, superciliary stripe, orbital region, and cheeks, dull white, finely mixed with brownish gray; sides of neck tate gray: auriculars slate gray, streaked with whitish; chin buify white: at haffy ochraceous spot on upper throat just back of the chin; rest of throat rather light gray, washed and streaked broadly with buff; posterior lower parts much paler than in the adult. This example shows only slight indications of molt.

Doctor Abbott reported this species as common on Pulo siantan from August 19 to September 6, 1s99; and observed it also on Puls Kelong, September 1, 1899. 
The following measurements of the adults of this race are all that could be taken with any reasunahle accuracy, owing to the molting condition of the wings and tail, and it is possible that the wing and tail dimensions here giren are, for the same reasin, somewhat less than they should be.

Measurements of specimens of Kittacincla malabarica ochroptila.
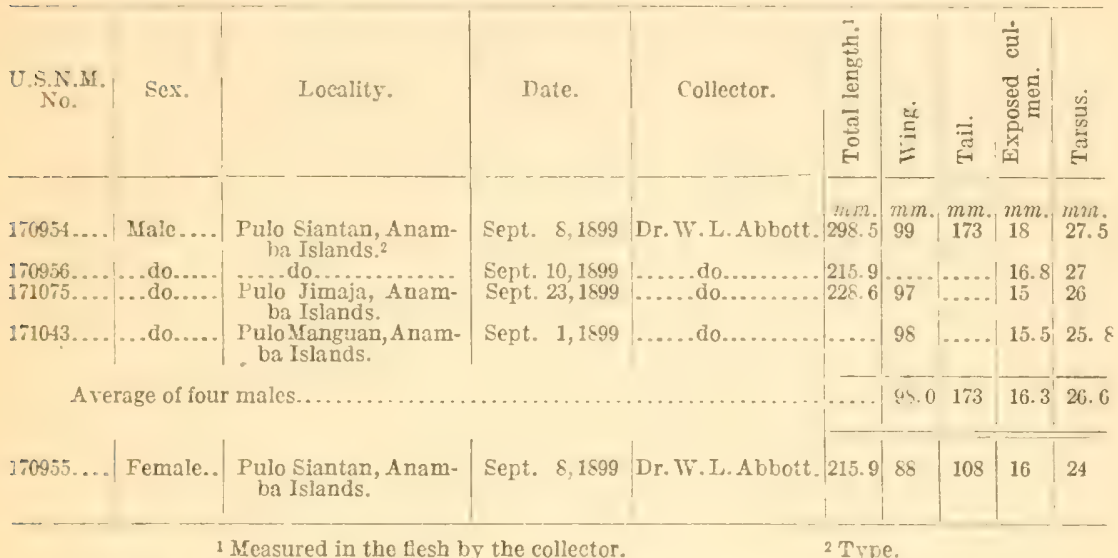

1 Measured in the tlesh by the collector.

2 Type.

KITTACINCLA MALABARICA HETEROGYNA, new subspecies.

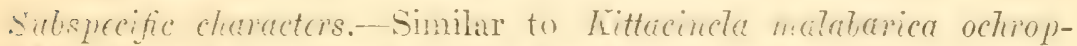
tila, ${ }^{3}$ thut fennale rery much darker, particularly on the throat, breast, and upper surface.

Description.-Type, adult female, No. 170918, U.S.N.M.; Pulo Riabu, Anamba Islands, August 18,1 Sn9; Dr. W. L. Abbott. Ifead, reck, juguhm, back, scapulars, lesser and median wing-overts, slate biack; rump and upper tail-coverts pure white; gresiter wing-corerts, prinary coverts, and winge-cuills, dark brewn, between sepia and clore hrown, these coverts somewhat darker, the greater scries narrowly margined externally with tawy; tail clove brown, the three outermost pairs of rectrices with hroud white tips on beth wobs, the fourth pair with a hread white tip confincel to outer weit: posterior lower surface tawny, the thighs and midele of abomen sunethat whitish; lining of wing tawn, a little mixed with whitisin and cusky. "Iris dark brown; feet fleshy white."

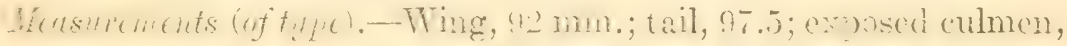
15.5; tarsus, 24.5 .

Geographic distribution.-Pulo Riabu and Pulo Piling, in the southern Anamba Islands.

Unfortunately, we hare no adult male of this new race, but the

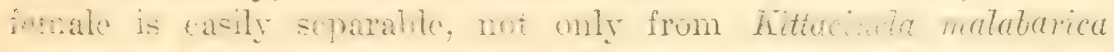


ochroptila, but from the other races of the spccies. It differs from Kittacincla malabarica malabarica (specimens from the Malay Peninsula) in its darker and more blackish throat and upper surface. It is even more different from Kittacincla malabarica suavis, for it has broad, brown bases to the outer rectrices, lighter, less metallic black (more slaty) upper parts and throat, and lighter posterior lower parts.

It is particularly interesting as being the only known instance of a second resident form of the same species on the Anamba Islands. It is apparently confined to Pulo Riabu, where Doctor Abbott says that it is fairly common; and to Pulo Peling, where he observed it, August 17, 1899.

Two specimens are in the collection - the type above described and an immature male, No. 170919, U.S.N.M., also from Pulo Riabu, taken, August 18, 1899. This bird is just beginning to molt from the juvenal into the adult plumage. The head, hind neck, and part of the back are still dull clove brown; the wings lighter brown of a more sepia tone, the quills rusty edged, and some of the coverts with tawny spots; the tail is short like that of the female, and dull colored; the sides of the head are dull brownish slate black, witi small ochraceous streaks; chin and throat dull brownish slate color with rather large spots of ochraceous; posterior lower parts deep tawny rufous, the middle of breast slightly mottled with blachish, and the middle of abdomen white.

\section{Family SYLVIIDAE.}

\section{ORTHOTOMUS ATROGULARIS (Temminck). 1}

Orthotomus atrogularis Temminck, Nouv. Rec. Planch. Color. d'Oiseaux, vol. 3. livr. 101, 1836, text to livr. 101 (Malacca and Borneo).

Seven specimens are in the collection, as follows:

Adult male, No. 171002, U.S.N.M.; Pulo Mobur, August 25, 1399. Length, $118 \mathrm{~mm}$. "Iris pale yellow brown."

Juvenal male, No. 171025, U.S.N.M.; Pulo Mata, August 29, 1899. Length, $108 \mathrm{~mm}$.

Juvenal male, No. 170970, U.S.N.M.; Pulo Siantan, September 5, 1899. Length, $115 \mathrm{~mm}$.

Juvenal male, No. 171001, U.S.N.M.; Pulo Mobur, August 25, 1899. Length, $109 \mathrm{~mm}$. "Bill dark horn brown, pale brownish fleshy beneath; feet dark fleshy brown."

Adult female, No. 170968, U.S.N.M.; Pulo Siantan, August 21), 1899. Length, $115 \mathrm{~mm}$. "Iris pale yellow brown."

Jurenal female, No. 170969, U.S.X.M.; Pulo Siantan, Angust :1, 1599. Length, $111 \mathrm{~mm}$. "Iris pale yellowish brown; feet pale brownish fleshy."

This is the original spelling of the specific name. 
Juvenal female, No. 171089, U.S.N.M.; Pulo Jimaja, September 23, 1899. Length, $111 \mathrm{~mm}$. "Iris yellow brown; feet fleshy brown."

Although the number of adults is too few to admit of a perfectly satisfactory comparison, they seem to be identical with birds from the Malay Peninsula which represent true Orthotomus atrogularis. The adult female is like the adult male, except that the black gular patch is much less extensive and broadly streaked with white.

The two youngest jurenal males (Nos. 170970 and 171001, L.S.N.M.) resemble the adult female, but have rather duller, lighter upper parts, particularly the pileum, with a mixture of olive green in the pileum; less black on the jugulum, and a wash of olive yellow across the breast.

The jurenal female is like the juvenal male, but entirely lacks the blackish on the jugulum and the olive yellow wash on the breast; the crown and forehead of one (No. 17i969, U.S.T.M.) are entirely olive green like the back, sare for one half-grown rufous feather; the forchead and sides of crown of the other (No. 171089, L.S.N.M.) are rufous, but the rest of the pileum is olive green.

The adult male (No. 171002, U.S.N.M.), taken, August 25, 1899, is in heary molt of contour feathers and is also molting some of the wing-quills; and the adult female (No. 170968, U.S.N.M.), taken, August 20,1899, is in the same condition. One of the juvenal males (No. 171025, U.S.N.M.), taken, August 29, 1899, is passing from the juvenal plumage into that of the first autumn, and has acquired the rectrices, nearly all the remiges, and approximately three-fourths of tho contour feathers. The two other juvenal males (No. 171001, U.S.N.M., August 25, 1899; and No. 170970, U.S.N.M., September 5, 1899) are just beginning to change from juvenal into the first autumn livery; and one of the jurenal females (No. 170969, U.S.N.M.), taken, August 21, 1899, is in the same condition. The remaining juvenal female (No. 171089, U.S.N.M.), taken, September 23, 1899, has apparently rather more than half completed the change to first autumn plumage.

Doctor Abbott found this tailor-bird common on Pulo Siantan from August 19 to September 6, 1899.

\section{Family GRACULIDAE.}

- GRACULA JAYANA PRASIOCARA, new subspecieg.

Subspecific characters. - Similar to Gracula jarana jartana. from Java, but larger; sides of crown more greenish.

Description.-Type, arult male, No. 170905, L.S.N.M.; Pulo Piling, Anamba Islanus, Aligust 17, 1899; Dr. W. L. Abbott. Entire plumage black. xeepting a large white spot on the middle of the six 
outer primaries; middle of crown, the back, jugulum, and lower part of thighs, with metaliic riolet or bronzy riolet sheen; throat and chin with a dull greenish blue sheen; sides of crown, sides of occiput, all of lower back, rump, upper tail-coverts, breast, abdomen, and crissum, with metallic bottle green sheen; margins of all the superior wingcoverts, except the greater series, with glossy bluish, greenish or riolet sheen; wing-quills and rectrices with slight bluish or greenish reflections, excepting the inner webs of the former, which are brownish, decidedly paler along the basal portion of the inner margin.

This new race is most nearly allied to Gracula javana javana, with which it agrees in size of lappets and in haring the supra-auricular bare space completely dirided by a line of feathers. So far as known it is confiner to the Anamba Islands. Birds of this species from Borneo and Sumatra seem to agree with those from Jara.

Doctor Abbott obtained seren specimens, four of which (Nos. 171039, 174721, 170995, and 170905, U.S.N.M.) show slight eridences of molt. He found the species common on Pulo Piling, August 17, 1899; and about Telok Ayer Bini on Pulo Siantan, September 5-6, 1899. The measurements of all the specimens collected are as follows:

Measurements of Gracula javana prasiocara.

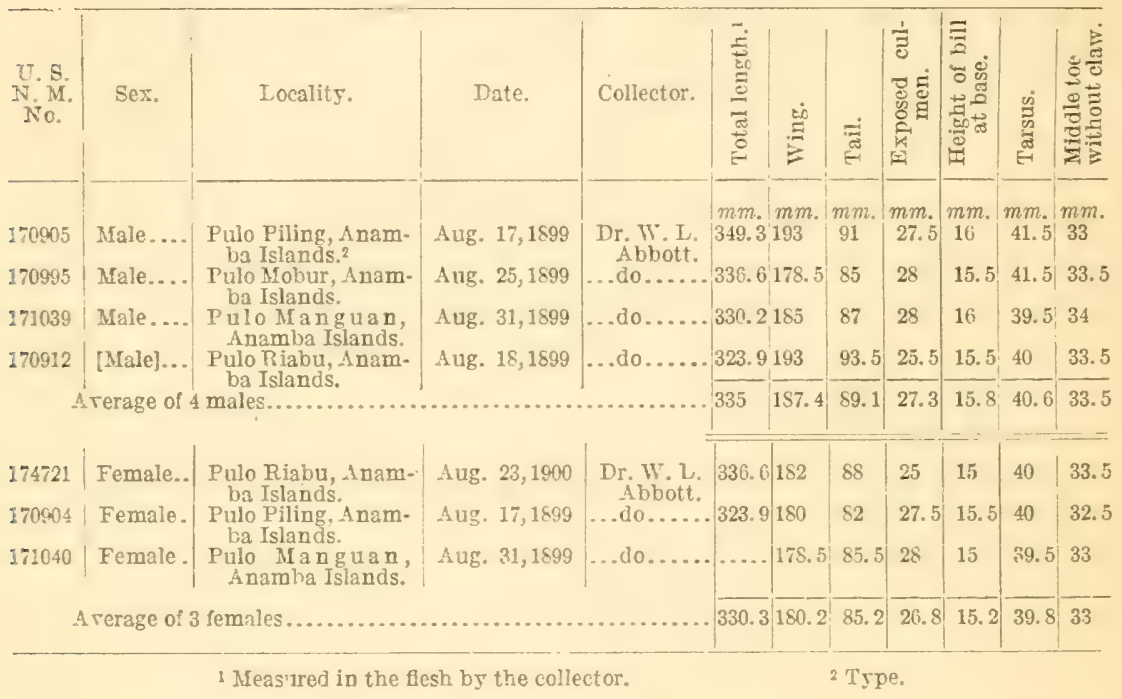

The present speries was first described in 1757 as Corme jaranensis by Osbeck, ${ }^{3}$ in a pre-Linnae:n book, which in 1761 was translated into English. This name has been in common use, dated from 1771, but accurding to mesent rules of nomenclature it is untenible, since the bock in which it appeared was a mere translation of an 
ineligible pre-Linnnean work. This being the case, the specics must take the name Cracula jarana, because Eulabes javamus Curier ${ }^{1}$ is the next a vailable specific designation. This change Doctor Hartert has already explained. ${ }^{2}$

\section{LAMPRocorax PANAYENSIS HETEROChlorus, new subspecies.}

Subspecific characters. - Similar to Lamprocorax panayensis strigatus, from Jara, but wery much larger, and plumage of male throughout more bronzy or oily green.

Description.-.'Type, adult male, No. 170996, L.S.N.M.; Pulo Mobur, Anamba Islands, August 26, 1899; Dr. W. L. Abbott. Entire plumage, exerpting the remiges and rectrices, metallic bottle green, with a slight bronzy tinge, the chin and throat with a somewhat purplish sheen: remiges and rectriees blakekish on upper surfnce, with steel greenish, bluish, and purplish reflections; lower surface of tail and wings blackish clove brown, the under wingcoverts and axillars margined with metallic green.

This new race is very distinct and separable at a glance from Lamprocorax panayensis strigatus of Jara by the characters abore given. It is, howerer, more closely allied to Lamprocorax panayensis panayensis, from which, in the male, as comparison with a lorge series of Plilippine sperimens shows, it differs in its more grassy; less cily or bronzy green upper parts, and particularly in its decidedly less bronzy lower surfuce, which is also mueh briginter green, particularly on the posterior pertions, where Lamprocorax panayensis panayensis is neaily always distinctly grayish.

Four specimens are in the collection, as follows:

Adult mile (typer), No. 170996, L.S.N.M.; Pulo Mołur, August 26, 1899. Length, $229 \mathrm{~mm}$.

Aduit mule, No. 170997, L.S.N.II.; irlet nuar Pulo Mobur, August 26, 1899. Length, $216 \mathrm{~mm}$.

Immature male, Ne. 170933, U.S.X.M.: Pulo Siantan, August, 1899.

Immetur, nir:L, No. 170sos, U.S.N.M.; islet near P'ulo Nobur, August 26, 1899. Length, $203 \mathrm{~mm}$.

The type No. 170gse) is in perfeet plumage: and the othere adult malis (No. 170997) is berrly so, though molting this under wingcorerts, with some of the wing-quills and body feathers. One of the immature birds (No. 170998) is in the jurentil plumage, which closely resembles the of the adult fons le, but is molting many of the body feathers. The other immature is similar but is more extensirely glossy green above, has the breast nearly solid green,

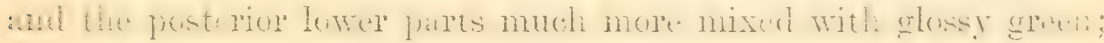
it is molting wing, tail, and body feather's. 
Doctor Abbott observed this bird on Pulo Mata, August 24 to September 1, 1899; and on Pulo Telaga, September 14-15, 1899.

The two adults measure as follows:

Measurements of specimens of Lamprocorax panayensis heterochlorus.

\begin{tabular}{|c|c|c|c|c|c|c|c|c|c|}
\hline $\begin{array}{c}\text { U.S.N.M. } \\
\text { No. }\end{array}$ & Sex. & Locality. & Date. & Collector. & 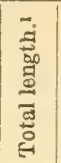 & 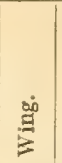 & $\overbrace{\tilde{\pi}}^{0}$ & 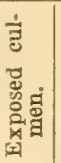 & 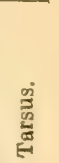 \\
\hline $\begin{array}{l}170996 \ldots \\
170997 \ldots . .\end{array}$ & $\begin{array}{c}\text { Malo..... } \\
\text {...do..... }\end{array}$ & $\begin{array}{l}\text { Pulo Mobur, Anam- } \\
\text { ba Islands. } \\
\text {..... do............... }\end{array}$ & $\begin{array}{l}\text { Aug. } 26,1899 \\
\ldots \text {...do........ }\end{array}$ & $\begin{array}{l}\text { Dr.W.L.Abbott.. } \\
\text {....do.............. }\end{array}$ & $\begin{array}{c}m m \\
229 \\
216\end{array}$ & $\begin{array}{c}m m \\
108 \\
112\end{array}$ & $\begin{array}{c}m m \\
76 \\
72.5\end{array}$ & $\begin{array}{c}m m \\
18 \\
20\end{array}$ & $\begin{array}{l}m m . \\
23.5 \\
23.5\end{array}$ \\
\hline
\end{tabular}

I Measured in the flesh by the collector.

2 Type.

The earliest name among the subspecies of Lamprocorax chalybeus of authors is of course Lamprocorax panayensis (Scopoli), ${ }^{3}$ which therefore becomes the name for the species as a whole, and of which Lamprocorax chalybeus becomes a subspecies. The proper designation for the last-mentioned form is, however, Lamprocorr.x panayensis strigatus Horsfield, ${ }^{4}$ because Turdus strigatus Horsfield ${ }^{4}$ has anteriority over Turdus chalybeus Horsfield ${ }^{5}$ of even date.

Some recent authors have united the genus Lamprocorax Bonaparte with Aplonis Gould, on the ground that the characters usually assigned to these groups are not constant. This is true, for in both form of bill and of tail there are intermediates, which might without violence find a place in either group. There is, however, a structural character which does hold good for the separation of all the forms of both genera examined. In Lam procorax the second (counting from the spurious outermost) primary is decidedly longer than the fifth, while in Aptonis it is usually shorter, sometimes equal, but never longer. Furthermore, the recognition of two genera by this criterion leaves all the species, with one exception, in the genera in which they have been. This exception is Aplonis cantoroides, and the necessity for its transferral was long ago suggested by Dr. R. B. Sharpe. ${ }^{6}$ The following species of these two genera have been examined in this connection:

Lamprocorax metallicus (Temminck) and subspecies.

Lamprocorax panayensis (Scopoli) and subspecies.

Lamprocorax todayensis Mearns.

Lamprocorax minor (Ramsay).

Lamprocorax cantoroides (Gray).

${ }^{3}$ Muscicapa panayensis Scopoli, Del. Flor. et Faun. Insubr., pt. 2, 1786, p. 96 (Panay Island, Philippine Islands).

4 Turdus strigatus Horsfield, Trans. Linn. Soc. Lond., ser. 1, vol. 13, pt. 1, May, 1821, p. 118 (Java).

- Turdus chalybeus Horsfield, Trans. Linn. Soc. Lond., ser. 1, vol. 13, Dt. 1, May, 1821, p. 148 (J373).

${ }^{6}$ Cat. Birds Brit. Mus., vol, 13, 1990, n. 125. 
Aplonis opaca (Kittlitz) (=Aplonis kittlitzi Autiors).'

Aplonis atrifusca (Peale).

Aplonis vitiensis Layard.

Aplonis brevirostris (Peale).

Aptonis tabuensis (Gmelin) (=Aplonis cassini Gray.

Aplonis atronitens Gray.

Aplonis striata (Gmelin).

\section{Family DICRURIDAE.}

$\rightarrow$ DISSEMURUS PARADISEUS MICROLOPHUS, new subspecies.

Subspecific characters.--Similar to Dissemurus paradiseus paradiseus of Siam, but frontal crest denser, stiffer, and very much shorter.

Description.-Type, adult male, No. 171074, U.S.N.M.; Pulo Jimaja, Anamba Islands, September 21, 1899; Dr. W. L. Abbott. Entire plumage brownish black, all the exposed parts of the body plumage, except on the chin, throat, abdomen, and flanks, glossy metallic greenish or bluish, this on the breast taking the form of apical spots, on the pileum and nape broad $V$-shaped terminal markings which leave more or less well-defined dull shaft streaks, these most conspicuous on the crown; wings and tail somewhat shiny brownish black, the rectrices and remiges with their outer webs mostly metallic greenish or bluish, the exposed surface of the upper wing-corerts similar; racquets large; crest short.

Eleven specimens are in the collection, from the islands of Siantan, Jimaja, Piling, Mobur, Riabu, and Telaga. All are more or less in process of molt; some have the long racquet feathers fully developed, others but partially, while one (No. 170907, U.S.N.M.) lacks them entirely. Among the adults there is comparatively little individual color variation, though some specimens are rather more bluish, others more greenish on the metallie portions of the plumage. Three (Nos. 170906, 170908, and 170934, U.S.N.M.) are immature, in which condition they differ from the adults in being much duller, the upper parts mixed with brown, the lower parts almost entirely dull brown, with very few metallic bluish or greenish feathers. Doctor Abbott notes that No. 170934 (immature) has the

1 This species has for long boon known as Aplonis kittlitzi (Finsch and Hartlaub) (Calornis kittlitzi Finsch and Hartlaub, Beitr. Fauna Contralpolyu., 1867, p. 109 [Ualan Island, Carolino Islands.\}). It was, however, first recognized and described by Kittliı (Kuplortafeln Naturgesch. Vögel, Heft 2, 1833, p. 11, pl. 15, fig. 2), who applied to it the names Turdus columbinus Gmelin (which is Lamprocorax panay. ensis Scopoli) and Lamprotornis opaca, a manuscript namo of Lichtenstein's, here first given nomen. clatural status by being publisbed with a description and a figure. The latter name is introduced by Kittlitz in the following fashion: "Fig. 2. Turdus columbinus Gm. L. oder Lamproth. opaca Lichtenstein, ein häufiger Vogel auf den Marianen und Carolinen, * * *." The species must therefore bear tho name Aplonis opaca (Kittlitz), since this is long prior to Aplonis kittlitzi (Finsch and Hartlaub). Subsequently G. R. Gray called it Calornis opaca (Cat. Birds Trop. Is. Pac. Brit. Mus., 1859, p. 26), using Lichtenstein's name opaca, and citing the above-mentioned descriptions aud figuro of Kittlitz, under the name "Lamprotornis columbina" Littlitz. 
grayish brown"; No. 170906 (immature), "iris brownish gray, bill and feet black"; and No. 170907 (adult), "iris red, bill and feet black."

Doctor Abbott further sars that the species was common on Pulo Telaga, September 14-15, 1899 ; fairly common on Pulo Piling, August 17, 1899; and one of the commonest birds on Pulo Siantan, Scptember 17-28, 1899. It was noted also on Pulo Kelong, September 1, 1899 ; and on Pulo Manguan, September 1-2, 1899 .

Detailed measurements of all the specimens collected by Doctor Abbott are given in the adjoining table.

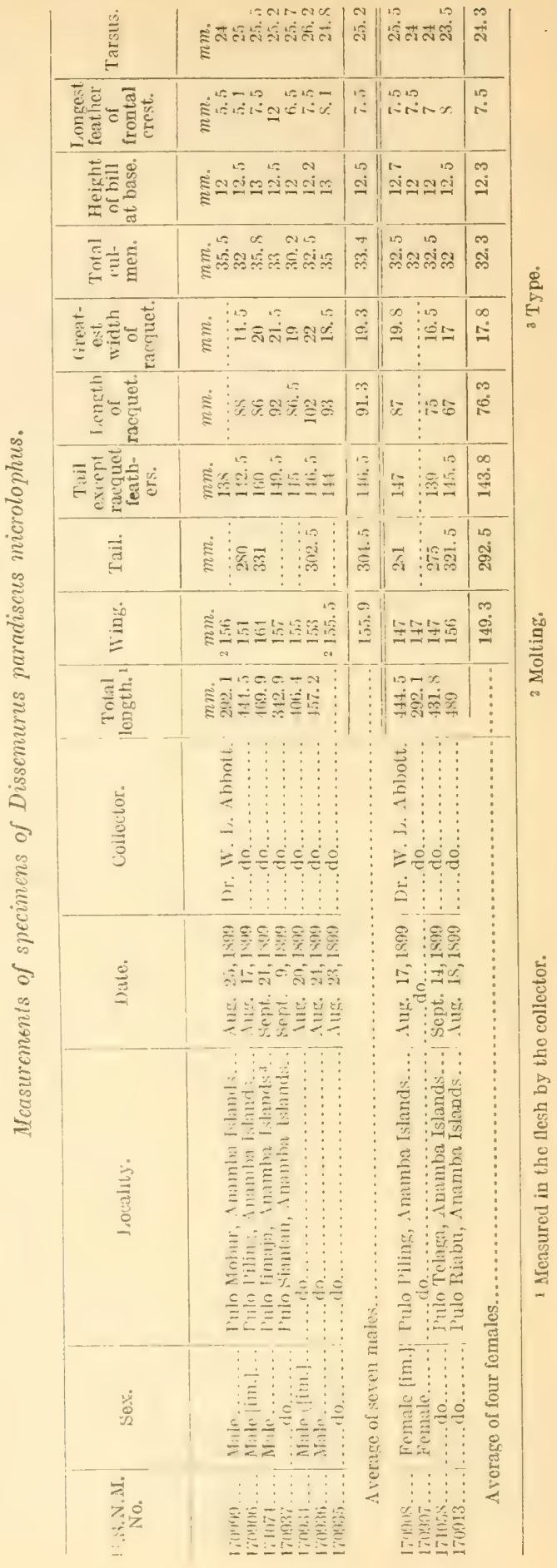


Family MOTACILLIDAE.

MOTACILLA BOARULA MELANOPE Pallas.

Motacilla melanope Pallas, Reise Versch. Prov. Russ. Reichз, vol. 3, 1776, p. 696 (Dauria, Siberia).

One apparently immature female, from Pulo Manguan, Septembe: 1, 1899. Length, $190.5 \mathrm{~mm}$.

\section{Family NECTARINIIDAE.}

ANTHREPTES MALACENSIS ANAMBAE, new subspecies,

Subspecific chemeters. - Male almost identical with same se:- of Anthreptes matacensis matarmsis, ${ }^{1}$ from the Malay Peninsula, but throat lighter; the yellow of median posterior lower surface averaging

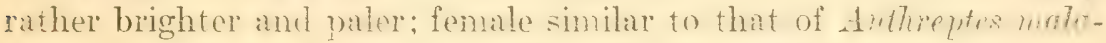
censis malacensis, but very much more greenish (less brownish or grayish) abore. muth more richly yellow beneath: inmatne matr

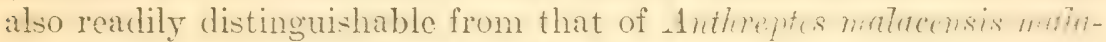

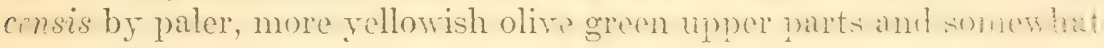
more yellowish lower surface.

Description.-Type, adult male, No. 171009, U.S.N.N.; Pulo Mobur, Anamba Islands, August 25, 1899 : Dr. W. L. Abhott. P'ilemm, cervix, back, ant siles of neck, iridesecnt metallie bottle groun, with some purplish reflections: rumen and upper tail-ererts metnllie raval purple; tail clove brown, most of the feathers with narrow metallic greenish or purplish external margins, the outer frather's rather lighter: wings giarish sepia, the quills and greatur corerts colged externally with olivaceous; median coverts and scapulars breally dnll burnt siema terminnlly; lesser coverts metallic royal purple: alites of head olive green: chin, throat, and jugulum, cinnamon rufous, bordered on each side by a conspicunus maxillar stripe of reyal purple: breast and abdomen lemon yellow; flankis and crissmu pale olive pellow; lining of wing white, mixed with pale yellow.

Both adult male and adult female of Antherptes maliter wis andminite

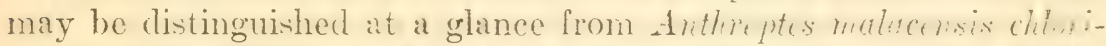
gaster, of the Philippine Istands, by the much brighter yedlus of the lower parts.

Immature males of Anthreptes malacensis anambae are very much like the adult female, but are somewhat more yellowith on the mon... surface. The immature female is very much like the adult of the same sex, but is rather lighter, more rellowish above, and -light: paler below.

Doctor Abbott obtained, altogeth sr, 15 specimens, as follows:

Adult male, No. 171102, U.S.N.M.; Pulo Jimaja, September 26, 1899. 
Anult male (type), No. 171009, U.S.N.M.; Pulo Mobur, August 25, 1899.

Adult male, No. 170984, U.S.N.M.; Pulo Siantan, August —, 1899. "Bill black abore, horny brown beneath; iris pinkish red; feet olive, soles yellowish."

Adult male, No. 170985, U.S.N.M.; Pulo Siantan, September 8 , 1899.

Adult male, No. 171037, U.S.N.M.; Pulo Kelong, August 30, 1899. Adult male, No. 171051, U.S.N.M.; Pulo Manguan, September 1, 1899.

Adult male, No. 171052, L.S.N.M.; Pulo Manguan, September 1, 1899.

Immature male, No. 171050, U.S.N.M.; Pulo Manguan, August 31, 1899. Length, $117.5 \mathrm{~mm}$.

Immature male, No. 174855, U.S.N.M.; Pulo Rittan, May 21, 1900. Length, $136.5 \mathrm{~mm}$.

Immature male, No. 170982, U.S.N.M.; Pulo Siantan, August 20, 1899. "Feet olive; soles yellow."

Immature male, No. 171027, U.S.N.M.; Pulo Mata, August 28, 1899. Adult female, No. 170983, U.S.N.M.; Pulo Siantan, August 24, 1899. Adult female, No. 171099, U.S.N.M.; Pulo Jimaja, September 18, 1899.

Adult female, No. 171100, U'.S.N.M.; Pulo Jimaja, September 21, 1899.

Immature female, No. 171101, L.S.N.M.; Pulo Jimaja, September 22, 1899 .

All of these specimens, excepting the single immature female (No. 171101, U.S.N.M.) and two of the immature males (Nos. 170982 and 174855 , U.S.N.M.), are more or less in progress of molt. The adult female from Pulo Siantan, taken, Angust 24 (No. 170983, U.S.N.M.), is in badly worn and much faded plumage and had just begun to molt. Some of the adult males have the back, cervix, and pileum almost wholly metallic riolet, but this seems to be an individual variation that appears in all the forms of Anthreptes malacensis.

Doctor Abbott noted this species common on Pulo Siantan, August 19 to September 6, 1899; on Pulo Jimaja, September 17-28, 1899; and nlso obserred it on Pulo Telaga, September 14-15, 1899.

The measurements of all the adults obtained by Doctor Abbott are given in the subjoined table. 
Measurements of specimens of Anthreptes malacensis anambae.

\begin{tabular}{|c|c|c|c|c|c|c|c|c|c|}
\hline $\begin{array}{l}\text { U.S.N.M. } \\
\text { No. }\end{array}$ & Ser. & Locality. & Date & - Collector. & 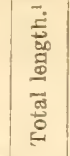 & $\stackrel{20}{E}$ & Еี & 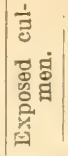 & 悹 \\
\hline $171009 \ldots$ & Male.. & Pulo Mobur, Anam- & Aug. 25,1899 & Dr. W. L. Abbott. . & $\begin{array}{r}m m . \\
139.7\end{array} \mid$ & $\begin{array}{l}m m \\
70.5\end{array}$ & $\begin{array}{l}m m \\
47.5\end{array}$ & $\begin{array}{l}m m \\
17.5\end{array}$ & $\begin{array}{l}m m .5 \\
18.5\end{array}$ \\
\hline $171037 \ldots$ & ... do.... & Pulo Kelong, An- & Aug. 30,1899 & .....do.. & & 70 & 47 & 18 & 17.5 \\
\hline $171102 \ldots$ & ...do..... & Pulo Jimaja, An- & Sept. 26, 1899 & .....do.... & 127 & 67.5 & $\ldots$ & 17.5 & 16.5 \\
\hline $170985 \ldots$ & ...do..... & Pulo Siantan, An- & Sept. 8,1899 & .....do.. & & & & $\ldots$ & 18.5 \\
\hline $\begin{array}{l}170984 \ldots \\
171051 \ldots .\end{array}$ & ...do...... & Pulo Manguan, An- & $\begin{array}{l}\text { Aug. - , } 1899 \\
\text { Sept. 1,1899 }\end{array}$ & ....do....... & $\begin{array}{r}139.7 \\
130.2\end{array}$ & 68.5 & 46 & $\begin{array}{l}17.5 \\
\ldots . .\end{array}$ & $\begin{array}{l}17.5 \\
18\end{array}$ \\
\hline $171052 \ldots$. & ...do..... & ..... do . . . & .....do... & .....do.. & $|133.3|$ & | 67.5 & $\ldots$ & 19 & 18.8 \\
\hline \multicolumn{4}{|c|}{$\Lambda$ rerage of 7 males... } & & $\ldots$ & 68.7 & 46.8 & 817.9 & 17.9 \\
\hline $170983 \ldots$ & Female. & Pulo Siantan, An- & Aug. 24, 1899 & Dr. IW. L. Abbott.. & 136.8 & 65 & 43.5 & 17.5 & 17 \\
\hline $171099 \ldots$ & ...do..... & Pulo Jimaja, An- & Sept. 18,1899 & .....do... & 114.3 & 66 & 43 & 16.5 & 16.3 \\
\hline $171100 \ldots$ & ...do..... & & Sept. 21, $1 \$ 99$ & .....do.. & $\ldots$ & 63 & 41 & 16.5 & 17 \\
\hline \multicolumn{3}{|c|}{ A rerage of 3 females ................ } & & & & | 64.7 & 42.5 & 16.8 & 16.8 \\
\hline
\end{tabular}

1 Measured in the flesh by the collector.

${ }^{2}$ Tspe.

t CINNYRIS BRASILIANA EUMECIS, new subspecies.

Subspecific characters.--Similar to Cinnyris brasitiana brasitiana ${ }^{1}$, from the Malas Peninsula, but larger, particularly the bill; female lighter above, and paler, more greenish (less golden) yellow below.

Description.-Type, adult male, No. 170974, U.S.N.M.; Pulo Siantan, Anamba Islands, September 6, 1899; Dr. W. L. Abbott. Pileum metallic grass green; lores black; sides of head and neck with hind neck and upper back, velvety black; lower back, rump, upper tail-coverts, and lesser wing-corerts, metallic deep verditer blue, with a pronounced violet sheen, this almost absent on upper tail-coverts; tail metallic indigo blue, with a riolet tinge; wings clore brown, the greater and median coverts, together with the tertials, velrety violet black; throat metallic violet; jugulum, breast, and upper abdomen maroon; rest of abdomen and crissum brownish black, the latter with the feathers margined with paler brownish; lining of wing black.

The following six specimens are in the collection:

Adult male, No. 17 I096, L.S.N.M.; Pulo Jimaja, September 18, 1899.

Arult male (tYpe), No. 17()st4, I'.S.T.M.; Pulo Simntin, September 6,1899 .

Immature male, No. 170n75, U.A.M.M.; Pulo siantan, September 6, 1899. Length, $95.5 \mathrm{~mm}$.

1 For the change of Cinnyris hasscltii to Cinnyris Gresiliana, see Gberto!ser, Smiths. Misc. Coll., vol. 60. Nio. 7 , October 26,1912 , p. 18 . 
Arult fomale, No. 170979, IT.S.N.M.; Pulo Simtan, September 6, 1899. "Feet black."

Adult femalo, No. 171056 , U.S.N.M.; Pulo Manguan, August 31 or Soptember 1, 1899. "Bill hlack, hrownish hereath at base; feet black."

Juvenal femele, No. 171097, L.S.X.M.; Pulo Jimaja, September 13 , 1899.

The two arlult males are identical exropt for the more golden shere of the metillic grom crown, the more violet throat, lower back, and rump, and the lighter shade of red on the breast and upper abdomen in the type; but these difforences are of course merely individual. These males are in molt about two-thirds to three-fourths completod. The immature male (No. 170975, U.S.N.M.) is still almost half in the olive green and olive yollow juvenal plumage, which closely resombles the adult fomale, though darker and duller above. This bird is in prowess of molt, and the posterior upper and lower parts and tail are wholly, the breast, upper back, and wings partly, in the adult plumago.

The two ahlut lemialew (Yos. 170979 and 171056 , U.S.N.M.) ar: i: nearly completed molt. The immature female (No. 171097, U.S.Y.Y., takm, september 19, 1899) is rery much like the andt female, but is considerably darker above, and on the breast haș obscure narrow dusky bars. It apparently has not yet begun to molt in to the adult plumage.

Doctor Ablote reported this sun-bird rommon at Telok Ayer Bin, on Pulo Siantan, September 5-6, 1899; and on Pulo Jimaja, Soptember 17-2s, 1899.

Measurements of the four adults are as follows:

Measurements of specimens of Cinnyris brasiliana eumecis.

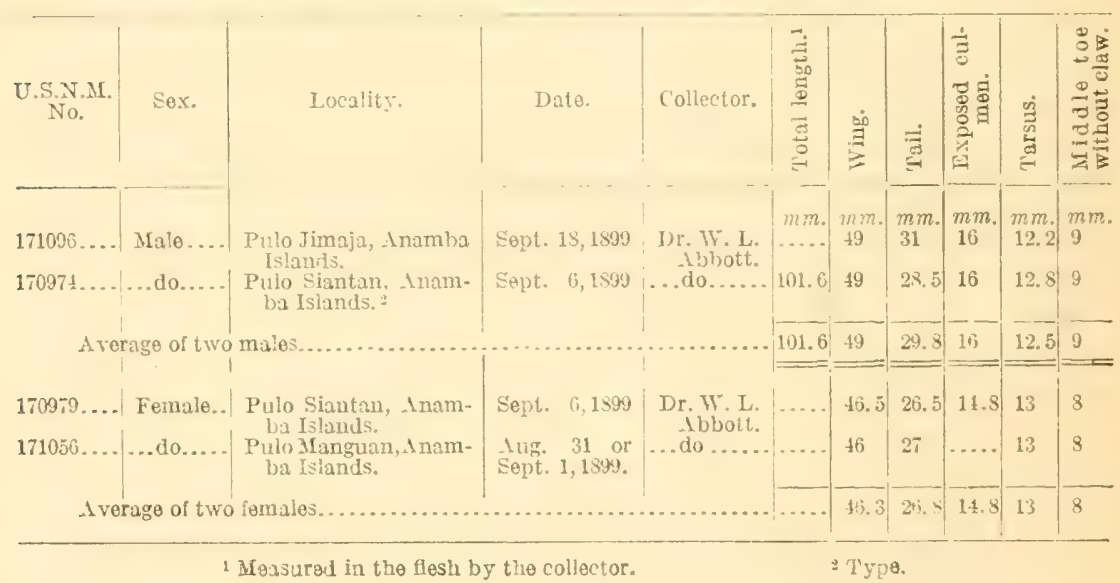


Subspecific characters. - Similar to Acthopyga siparaja siparaja from Sumatra, but larger; adult male with red of anterior lower parts lighter; posterior lower parts paler, less blackish medially, and areraging slightly less olivaceous laterally. Young male lighter, more grayish or greenish (less golden) olive green above, and paler, less olive yellowish below.

Description.-Type, adult male, No. 174850, U.S.N.M.; Pulo Rittan, Anamba Islands, May 21, 1900; Dr. W. L. Abbott. Forehead and fore part of crown metallic plum purple; lores black; sides of head and neck, occiput, cerrix, scapulars, upper back, and lesser wing-coverts rather light maroon; lower back brownish slate; rump cadmium yellow; upper tail-coverts metallic royal purple; tail brownish black, the middle feathers and outer webs of most of the others margined with metallic purple; wings dark hair brown, the outer primaries narrowly edged with palo brownish, the secondaries, greater and middle coverts, narrowly margined with olive green; chin, throat, and jugulum, scarlet vermilion; a long submalar streak metallic bluish purple; posterior lower parts brownish mouse gray, the middle of breast dark brownish, the flanks slightly washed with olivaceous; lining of wing mostly dull white, exteriorly hair brown.

Fifteen specimens are in the collection, as follows:

Adult male (type), No. 174850, U.S.N.M.; Pulo Rittan, May 21, 1900.

Adult male, No. 170977, U.S.N.M.; Pulo Siantan, August 20, 1899. Adult male, No. 171008, U.S.N.M.; Pulo Mobur, August 27, 1899. Adult male, No. 171007, U.S.N.M.; Pulo Mobur, August 27, 1899. Adult male, No. 171028, U.S.N.M.; Pulo Mata, August 29, 1899.

Adult male, No. 171038, U.S.N.Mf.; Pulo Kelong, August 30, 1899. Adult male, No. 17105t, U.S.N.MI.; Pulo Manguan, August 31, 1899 .

Adult malo, No. 171098, U.S.N.M.; Pulo Jimaja, September 19, 1899 .

Juvenal male, No. 171053, U.S.N.M.; Pulo Manguan, August 31, 1899. Length, $108 \mathrm{~mm}$.

Jurenal [male], No. 171055, U.S.N.M.; Pulo Manguan, September 1, 1899. "Bill black above, becoming pale fleshy brown at base beneath; feet dark fleshy brown; soles yellowish." Length, $101.5 \mathrm{~mm}$. Juvenal male, No. 170978, U.S.N.Mi.; Pulo Siantan, September 6, 1899. Length, $105 \mathrm{~mm}$.

Juvenal male, No. 170980, U.S.N.M.; Pulo Siantan, September 6, 1899. Length, $92 \mathrm{~mm}$.

Juvenal [male], No. 170981, U.S.N.M.; Pulo Siantan, September 10, 1899. Length, $108 \mathrm{~mm}$.

$70536^{\circ}-$ Bull. $98-17-5$ 
Juvenal male, No. 170976, U.S.N.M.; Pulo Siantan, August 20, 1899.

Adult female, No. 171061, U.S.N.M.; Pulo Telaga, September 15, 1899. Length, $105 \mathrm{~mm}$.

The adult males exhibit little individual color variation except on the posterior lower parts, which are in some specimens darker, more slaty. The colors of the plumage are apparently unaffected to any appreciable degree by wear, except that the red of the upper parts becomes rather duller in late summer. All the adult males taken between August 20 and September 19, inclusive, are more or less in process of molt.

The male in jurenal plumage is at first practically like the adult fomale, though somowhat darker and duller or more broizy, and usually with a touch of red on ehin, throat or back. From this stage it passes directly into the adult livery by molt in the first autimn. One of Doctor Abbott's specimens (No. 170980, L.S.N.M.) is all in female plumage, except for a rery slight wash of red on the chin; another (No. 171055, U.S.Y.M.) is similur, though dartker an d duller on the anterior lower parts, and with a slight reddish wash over most of the throat; mother (No. 170978, C.S.N.M.) is like the last, but with a more extensive and conspictious red gular path; while a fourth lacks entirely the red on chin and throat, but has a large red area on the back. In all four of the jurenal malcs just mer tion ed the redtipped foathers aro evidently of the juveral plimage, becuuse they havo olive-green bases, not blackish or white as have the red feathers of the adult. One inmature male (No. 171053, U.S.N.M.) tilke?:, August 31,1899 , is still in parily jurenal plumige, but has already acquired part of the adult dress in the brownish gray posterior lower parts; the yollow rump; the purple upper tail-coverts; purplish roctrices, though most of these wre but partly grown; a live of red forthers down the middle of the throat, and many seattered red feathers ois the sides of the neck, on cervix, back, and scapulars; ard a few purplish metallie feathers on the forchead and in the submalur streak. The romaining jurenal male (No. 170976, U.S.N.M., Aug. 20) is in the plumage of tho femate, except for a redelish wash on the throat, and a fow scattered bright-colored feather's of the adult livery, in to which it is just beginning to molt.

Doctor Abbott reports that ho found this spocios abundant on Pulo Manguan; and that in eary Sontember it was the commorest sun-bird on Pulo Siantan, where it inhabits the thick forest. ${ }^{1}$

Moasurements of all the ariats in Doctor Abbott's colloction are to be found in the following table: 
Measurements of specimens of Aethopyga siparaja ochropyrrha.

\begin{tabular}{|c|c|c|c|c|c|c|c|c|c|c|}
\hline $\begin{array}{c}\text { U.S.N.M. } \\
\text { No. }\end{array}$ & Sex. & Locality. & Date. & Collector. & 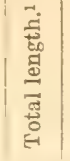 & $\stackrel{+\infty}{g}$ & تृं & 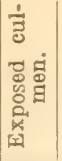 & 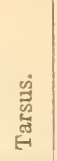 & 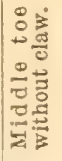 \\
\hline $174550 \ldots$ & Malo.... & Pulo Rittan, Anamba & May 21,1900 & Dr. W. I. & $\begin{array}{l}m m \\
114.3\end{array}$ & $\begin{array}{l}m m .1 \\
50.5\end{array}$ & $\begin{array}{l}m m \\
41.5\end{array}$ & $\begin{array}{c}m m \\
16\end{array}$ & $\begin{array}{l}m m \\
12.7\end{array}$ & $\begin{array}{l}m m .8 \\
8.8\end{array}$ \\
\hline $170977 \ldots$ & ...do..... & Pulo Siantan, Anam- & Aug. 20, 1899 & $\begin{array}{l}\text { Abbott. } \\
\text {...do....... }\end{array}$ & $\ldots$. & 48 & & 14.2 & 12.5 & 9 \\
\hline $171007 \ldots$ & ...do..... & $\begin{array}{l}\text { Pulo Mobur, Anamba } \\
\text { Islands. }\end{array}$ & Aug. 27, 1899 & ...do.. & & 51.5 & 38 & 15.5 & 14.5 & .8 \\
\hline $\begin{array}{l}171009 \ldots . \\
171028 \ldots\end{array}$ & $\begin{array}{l}\ldots \text { do..... } \\
\ldots \text { do.... }\end{array}$ & Pulo Mata, Anamba & Aug. 29,1899 & $\begin{array}{l}\text {..do. } \\
\text {...do. }\end{array}$ & ..... & $\begin{array}{l}52.5 \\
50.2\end{array}$ & $\cdots$ & $\begin{array}{c}15.5 \\
\cdots \cdots\end{array}$ & $\begin{array}{l}14 \\
13.2\end{array}$ & $\begin{array}{l}8 \\
7.5\end{array}$ \\
\hline $171038 \ldots$ & ...do..... & $\begin{array}{l}\text { Islands. } \\
\text { Pulo Kelong, Anam- }\end{array}$ & Aug. 30,1899 & ...do.. & 111.2 & 52 & 42 & 15.5 & 13 & 8 \\
\hline $171054 \ldots$ & ...do.... & Pulo Manguan, & Aug. 31,1899 & ...do.. & 117.6 & 51 & 43.8 & 14.9 & 13.5 & 8.5 \\
\hline $171098 \ldots$ & ...do..... & $\begin{array}{l}\text { Pulo Jimaja, Anamba } \\
\text { Islands. }\end{array}$ & Sept. 19, 1899 & ...do... & 114.3 & 51 & 42.5 & $\cdots \cdot$ & 13.5 & 8 \\
\hline \multicolumn{5}{|c|}{ Arerage of 8 males.................. } & 114.4 & 50.8 & 41.6 & 15.3 & 13.4 & 8.2 \\
\hline $171061 \ldots$ & Female.. & $\begin{array}{l}\text { Pulo Telaga, Anamba } \\
\text { Islands. }\end{array}$ & Sept. 15,1899 & $\begin{array}{l}\text { Dr. W. L. } \\
\text { Abbott. }\end{array}$ & $|104.9|$ & 46 & 34 & 15.3 & 13 & 7.8 \\
\hline
\end{tabular}

1 Measured in the flesh by tho collector.

2 Type.

\section{Family DICAEIDAE.}

\section{DICAEUM TRIGONOSTIGMUM HYPOCHLOUM, new subspecies.}

Subspecific characters. - Similar to Dicoeum trigonostigmum trigonostigmum, ${ }^{1}$ from the Malay Peninsula, but male with gray of throat ard slaty blue of upper parts and wings paler; jureral fomale duller, more giayish (less greenish) above, and less yellowish bolow.

Description.-Type, immaturo male, No. 170972, U.S.N.M.; Pulo Siuntan, Anamba Islands, September S, 1S99; Dr. W. L. Abbott. Pileum, corrix, back, scapulars, sides of head, and sides of reck, rather light slaty blue (but still much mixed with the olire green and grayish olire foathers of the jurenal plumage); rump ard shorter upper tiil-coverts siffron yollow; longest upper tail-coverts slity blue like the upper parts; tail-fouthers fuicous, marrowly margined with dull olive green; wings fuscous, the superior coverts and quill-edgings mostly siaty hlue, the inner margin of basal portion of primaries and secondaries white; (hin and throat light hlue gray; breast and sides cadinium orange; abdomen, flanlss, ard crissum, wax yellow, the middle of abiomen lighter; thighs pale yellowish gray; lining of wing yellowish whito.

Four specimens are in the collection, as follows:

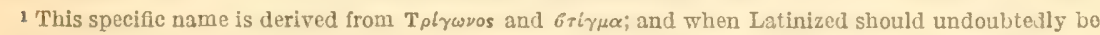
treated as an adjectivo. Thus after dicaeum, a neuter name, it should bo trigonostigmum, not trigonostigma, as usually written. 
Nearly adult male (type), No. 170972, U.S.N.M.; Pulo Siantan, September 8, 1899.

Immature male, No. 170971, U.S.N.M.; Pulo Siantan, September 5,1899 .

Juvenal female, No. 170973, U.S.N.M.; Pulo Siantan, September 9, 1899 .

Juronal female, No. 171006, U.S.N.M.; Pulo Mobur, August 26, 1899. "Bill horn brown, orange beneath at base."

Unifortunately neither of our two males is fully adult; but the plumage of the lower parts, in the type particularly, is practically complete; while there are enough new slate blue feathers of the adult phumage on the upper surface to show the difference in color between the Anamba birds and those from the Malay Peninsula. The contrast between the fomales, both adult and young, of these two races is even more striking. The present form is, by reason of its much paler throat and upper surface, still more different from Dicaeum trigonostigmum antioproctum Oberholser, ${ }^{1}$ of Simalur Islind; Dicaeum trigonosiigmum Typrum Oberholser, ${ }^{1}$ of Nias Island; and Dicaeum trigonostigmum mela the Oberholser, ${ }^{1}$ of Pulo Lasia, western Sumatra.

Both of the males (the type, No. 170972, U.S.N.M., September 8, and No. 170971, U.S.N.M., September 5) are molting from the juvenal into the adult plumage, the former speciman with this molt about three-quarters emplete; the latter with about a third part of the adult oriv!ge and a thind of the abult blue-gray feathers of the lower parts, but with only a fow scattered adult feathers in the plumage of the upper surface, wings, and tail, which are still in jurenal livery. The juvenal plumage of the male is practically like that of the adult fomale. One of the jurenal fomales (No. 171006, U.S.N.M., August 26 ) is in complete jurenal plumage, and shows no evidence of molt. In this stage the anterior lower parts are darker, duller, more slaty than in the adult. The other fomale (No. 170973, U.S.N.M., Soptember 9 ) is about a third molted into the aiult plumage, all but most of the lower surface of the body being still in juvenal livery.

Doctor Abbott reported this species common on Pulo Siantan, August 19 to September 6, 1899; also on Pulo Jimaja, September 17-2S, 1899; and ho obserred it on Pulo Mata, August 24 to Soptember 1, 1899; and on Pulo Telaga, September 14-15, 1899.

Although none of our spocimens are entirely adult, they seem to be nearly or quite full growu. Their measurements aro as follows: 
Measurements of specimens of Dicaeum trigonostigmum hypochloum.

\begin{tabular}{|c|c|c|c|c|c|c|c|c|c|c|}
\hline $\begin{array}{c}\text { U.S.N.M. } \\
\text { No. }\end{array}$ & Sex. & Locality. & Date. & Collector. & 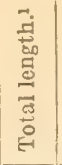 & $\stackrel{\infty}{\Xi}$ & 局। & 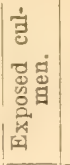 & 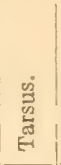 & 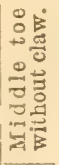 \\
\hline $\begin{array}{l}170972 \ldots \\
170971 \ldots\end{array}$ & $\begin{array}{l}\text { M a l e, } \\
\text { vix ad. } \\
\text { Ma lo } \\
\text { juvenal. }\end{array}$ & $\begin{array}{l}\text { Pulo Siantan, Anam. } \\
\text { ba Islands. } \\
\ldots . . . \text { do.................. }\end{array}$ & $\begin{array}{l}\text { Sept. } 8,1899 \\
\text { Sept. } 5,1899\end{array}$ & $\begin{array}{l}\text { Dr. W. L. } \\
\text { Abbott. } \\
\ldots \text { do........ }\end{array}$ & $\begin{array}{r}m m . \\
88.9 \\
95.3\end{array}$ & $\begin{array}{c}m m . \\
49.5 \\
51\end{array}$ & $\begin{array}{l}m m . \\
23.5 \\
24\end{array}$ & $\begin{array}{l}m m .1 \\
10.1 \\
10.1\end{array} \mid$ & $\begin{array}{l}m m \\
13 \\
14\end{array}$ & $\begin{array}{r}m m . \\
8.3 \\
7.7\end{array}$ \\
\hline \multicolumn{2}{|c|}{$A$ verage of two } & males................. & & & 92.1 & 50.3 & 23.8 & 10.1 & 13.5 & 8.0 \\
\hline \multirow[t]{2}{*}{$\begin{array}{l}170973 \ldots \\
171006 \ldots\end{array}$} & $\begin{array}{c}\text { Female, } \\
\text { juvenal. } \\
\text { do...... }\end{array}$ & $\begin{array}{l}\text { Pulo Siantan, Anam- } \\
\text { ba Islands. } \\
\text { Pulo Mobur, Anamba } \\
\text { Islands. }\end{array}$ & $\begin{array}{l}\text { Sept. } 9,1899 \\
\text { Aug. 26,1899 }\end{array}$ & \multirow[t]{2}{*}{$\begin{array}{l}\text { Dr. W. L. } \\
\text { Abbott. } \\
\text { do......... }\end{array}$} & 88.9 & $\begin{array}{l}46 \\
50\end{array}$ & 23 & 10 & $\begin{array}{l}13 \\
13\end{array}$ & $\begin{array}{l}8 \\
7.8\end{array}$ \\
\hline & rage of $t w 0$ & females............. & & & 88.9 & 48 & 22.5 & 10.3 & 13 & 7.9 \\
\hline
\end{tabular}





\section{INDEX.}

[Figures in black-faced type indicate family, specific or subspecific headings.]

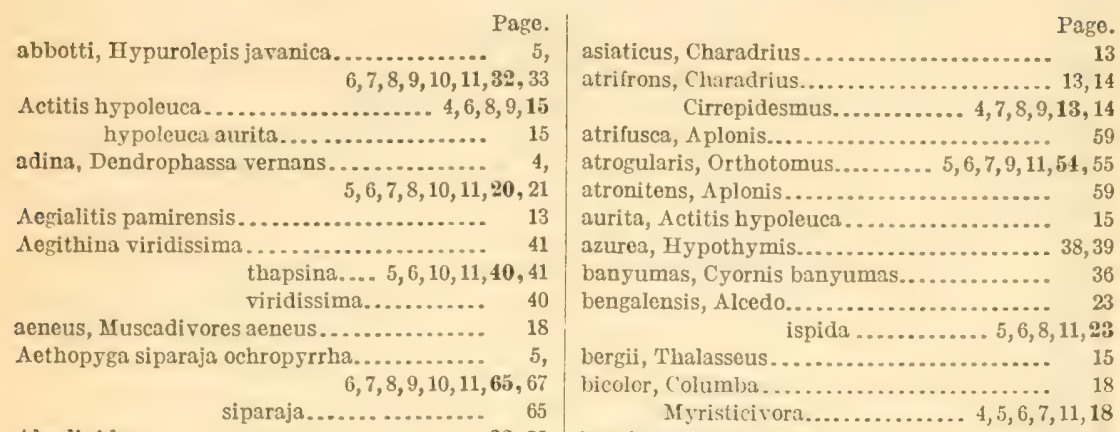

Alcedinidae............................22,25

Alcedo.............................. 26 bengalensis...................... 23 ispida bengalensis............ 5, 6, $8,11,23$ ispidit.................... 23

Alcippe magnirostris.................. 47

Alesone............................ 26 amechana, Collocalia fuciphaga........... 1,27 vestita....... 5, 9, 10,11,27

amelis, Hypothymis azurea............... 40 anambae, Anthreptes malacensis.......... 5 , $6,7,8,9,10,11,61,63$ Anous stolidus pileatus ................ 4,11,17 Anthreptes malacensis.................. 62 anambæ.......... 5 , $6,7,8,9,10,11,61,63$ chlorigaster......... 61 malacensis.......... 61

antioproctum, Dicaeum trigonostigum..... 68 Anuropsis malaccensis malaccensis .... $5,7,9,11,48$ Aplonis.

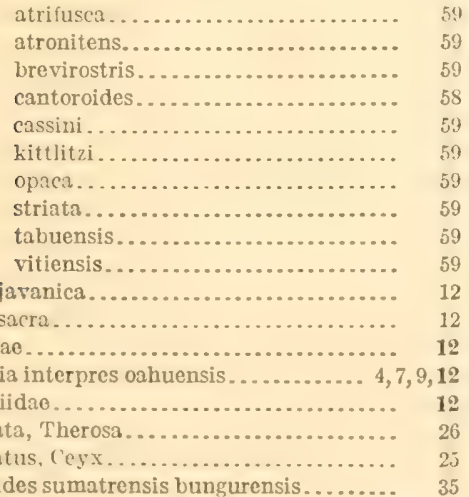
calopolius. $5,7,10,11,31,35$ dificicilis............ 35 sumatrensis.......... 34

Brachypteryx malaccensis.................. 48

Brachypus modestus..................... 46

brasiliana, Cinnyris...................... 63 brasiliana............. 63

brevirostris, Aplonis..................... $\quad 59$

brunneus, Pycnonotus................... 44,46

brunneus........... 45,46

bungurensis, Artamides sumatrensis........ 35 Graucalus.................... 35

Butconidae....................... 12

Butorides javanicus javanicus........... 4,11,12 virescens.................... 1

calocara, Hypothymis azurea............. $\quad 39$

Caloenas nicobarica.................. 4,11,17 calopolius, Artamides sumatrensis.5, 7, 10, 11, 34, 35

Calornis hittlitzi....................... 59 opaca........................ 59

Campophagidae........................ 34

cantoroides, Aplonis...................... $\quad 58$

Lamprocorax................ 58

cassini, Aplonis....................... $\quad 59$

Ceyeis................................ 25

ceylonensis, Hypothymis azurea........... $\quad 39$

(eyx ................................ 25

argentatus........................ 25

cyanopectus....................... 25

dillwynni.......................... 23

enopopygius..................... 23

cuerythri....................... 23

rufidorsia...................... 23

robusta................... 23

rufidorsus innominatus............... 23

rufidorsus............. 5, 9, 11, $\mathbf{2 3}$

sharpei.......................... 23

solitarius.......................... 25

tridactylus..................... 23,24, 25

macrocarus..............21, 25

tridactylus................ 24,25

Chalcophaps indica indica............4,7,11,17

chalybeus, Iamprocorax................. 58

Turdus........................ 58

chalyburus, Muscadivores aeneus.......... 19 
Charadriidae.

Charadrius asiaticus

\section{atrifrons.}

cinclus.

f

geoffrori..................... 13

inconspicutus.................. 13, 14

leschenaultii.

pyrrhothorox.................. 13

Chelitom.... . .

chiroplethis, Pycnonotus plumosus........ 5 5,

$6,7,10,11,41,43$

chloeodis, Pycnonotus olivaceus............ 44, 43

chlorigaster, Anthreptes malacensis......... 61

cinclus, Charadrius........................ 12

Cinnyris brasiliana..................... 63

brasiliana............. 63

enumecis.. $5,7,5,9,10,11,68,64$

hasseltii................. 63

Cirrepitiesmus.......................

atrifrons...........4, $\mathbf{7}, 8,9, \mathbf{1 3}, 14$

Claraviirl: .......................... 17

coeruleocephala, Hypothymis azurea....... 39

Collocalia fuciphaga amechana............. 1,27 lowi.................. 5,6, 11, 26, 27 palawanensis................ 20

origenis...................... 27

vestita amechana.........5, 9, 10, 11, 27

whiteheadi.................. 26, 27

palawanensis .........26, 26

whiteheadi........... 26, 27

Columba bicolor.......................... 18

indica.......................... 17

nicobarica.

columbina, Lamprotornis

columbinus, Turclus.

comata, Hemiprocne comata.

comatus, Cypselus......................... 28

consobrina, IIypothymis azurea ............ 40

Conurus longicaudus .................. 5,8,11,21

cristatus, Lanius........................ 5, 9, 31

Cuculidae............................... 22

Cuneuma leucogastris . ............. 4, $5,6,8,11,12$ cyanescens, Sauropatis chloris........ $5,6,7,11,22$ cyanopectus, Cerx........................ 25

Therosa.................... 26

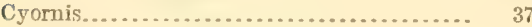

banyumas banyumas............. 36

lampra. . 5, 6, 7, 8, 9, 10, 11, 35, 37 philipninensis........... 35,36

Cypselus. ...................... 26

comatus....................... 28

subfurcatus.................... 26

Demiegretta sacra sacra. ............... $4,11,12$

Deudrophassa.......................... 20 vernans adina............. 4 , $5,6,7,8,10,11,20,21$ vernans........... 20

Dicaeidae............................ 67

Dicaeum trigonostigma.................... 67

trigonostigmum antioproctum.... 68

hypochloum..... 5

$7,10,11,67,69$

lyprum .......... 68

melantho......... 68

trigonostigmum... 67
Dicruridae........................... Page.

difficilis, rtamides sumatrensis............ 35

Graucalus sumatrensis............ 35

dillwynni, Ceyx........................ 23

Dissemurus paradiseus microlophus........ 5 ,

$6,7,8,9,10,11,59,60$

paradiseus........... 59

domicola, Hirundo..................... 34

Hypurolepis javanica.............. 33

enopopygius, ('eyx................... 23

Entomothern........................... 22

erythrogaster, Hirundo.................... 31

erythrogastra, Hirundo..................... $\quad 31$

erythrogastris, Hirundo . . . . . . . . . . . . . . . . 29, 31

Hirundo rustica.............. 29,31

crythrognathus, Phoenicophaeus........... 22

Urococcyx............ $5,6,11,22$

euerythra, Ceyx........................ 23

Eulabes javanus.......................... 57

eumecis, Cinnyris brasiliana..... 5, $7,9,10,11,63,64$

Eupoda............................... 13

eurhinus, Totanus totanus............. 4,8,9,14

everetti, Mixornis pileata................... 49

Falco leucogaster......................... 12

forrestia, Hypothymis azurea............... 39

Fregata minor minor................. 4,11,12

Fregatidie........................... 12

frontalis, Hirundo......................... 33

Hypurolepis frontalis............ 33

fulva, Pluvialis dominica................ 4, 9,13

fulvus, Charadrius......................... 13

galgulus, Loriculus..................... 4, 11, 21

Psittacus...................... 21

geoffroyi, Charadrius...................... 13

gigantoptera, Hypothymis azurea.......... $\quad 40$

Gracula javana......................... $\quad 57$ javana..................55,56 prasiocara..... $5,6,7,8,10,11,55,56$

Graculidae............................ 55

Graucalus bungurensis................... $\quad 35$

sumatrensis difficilis. ............ 35

gularis, Mixornis........................ 49

Motacilla........................ 49

gutturalis, Hirundo..................... 28, 29

rustica........5, $9, \mathbf{2 8}, 29,30,31$

Halcyon.............................. ${ }_{22}$

halizonus, Pycnonotus simplex........... 5 ,

$6,9,10,11,43,44,45,46$

harterti, Hemiprocno Iongipennis........ 5, 9, 11, $\mathbf{8 8}$

hasseltii, Cinnyris ...................... 63

Hemiprocne............................ 28

comata comata............. 5, 11, 28

longipennis................. 28

harterti....... 5, $9, \mathbf{1 1}, \mathbf{2 8}$

longipennis........ 28

ocyptera............ 28

perlonga........... 28

thos............... 28

Hemiprocnidae......................... 28

Herse.................................... 34

heterochlorus, Lamprocorax panayensis.... 5,

$6,7,8,10,11,57,58$

heterogyna, Kittacincla malabarica........ 5, $6,7,10,11,53$

Hirundinidae........................ $\quad \mathbf{2 8}$

Hirundo.............................. 30, 32 
Hirundo domicola. ..................... Page. erythrogaster................... 31 erythrogastra.................... 31 palmeri............. 29 erythrogastris................... 29, 31 frontalis........................ 33 gutturalis................... 25, 29 javanica...................... 32 neoxena......................... 34 rustica....................... 30,32,34 erythrogastris............ 29, 31 gutturalis....... $5,9,28,29,30,31$ rustic............... $29,3 n, 31$ sarignii................. 30,31 transitiva............29,30,31 tytleri.............. 29, 30,31 savignii...................... 29, 31 subfusea...................... 34 tahitica........................ 34 tytleri.......................29, 30

Horizillas............................... 48 magna........................ 48 magnirostris.............. 5, 7,9, 11,47 hypochloum, Dicacum trigonostigmum ..... $7,10,11,67,69$ hypoleuen, Actitis................. 4,6, $8,9,15$ hypoleucos, Tringa. Hypothymis azurea amelis................ 40 azurea............... 8 ₹, 39 calocara.............. 39 ceylonensis.............. 39 coeruleocephala......... 39 consobrina............. $\quad 40$ forrestia............... 39 gigantoptera........... 40 idiochroa................ 39 isocara................ 40 leucophila.............. 40 nicobarica.............. 39 oberholseri............... 39 opisthocyanea.......... 1 , $5,6,8,9,11,38,39,50$ ponera................. 40 prophath............. 39 richmondi............. 40 styani................ 39 symmixta............. 40 tyticri................. $\quad 39$ Hypurolepis ............................ 34 javanica abbotti............... 5 , $6,7,8,9,10,11,32,33$ domicola............ 33 frontalis.............. 33 javanica............. 32,33

Idiochroa, Hypothymis azurea.............. 39 inconspicuus, Charadrius.................. 13, 14

indica, Chalcophaps indica........... 4, 7, 11, 17 Columb:a. Iole olivacea............................... 44 isocara, Hypothymis azurea................ 40 ispida, Alcedo ispida....................... 23 javana, Gracula...................... 57 janana.................. 55,56 jivanicu, Arclea

Hirundo...................... 32

Hypurolepis javanica.............. 32,33

javanicus, Butorides javanicus.......... 4,11,12

jaranus, Eulabes.......................... 57

Kittacincla macroura................... 51

malabarica.................. 5,51

heterogyna.. $5,6,7,10,11,53$

malabarica........... 54

ochroptila......... 5,6,

$7,8,9,10,11,51,53$

suavis.............5 51,54

kittlitzi, A plonis...................... 59

Calornis....................... 59

Iampra, Cyornis banyumas.. $5,6,7,8,9,10,11,35,37$

Lamprocorax.......................... 58

cantoroides................. 58

chalybeus................... 58

metallicus................... 58

minor....................... 58

panayensis.................. 58,59 heterochlorus..... 5, 6 , $7,8,10,11,57,58$ panayensis......... 57 strigatus......... 57,58

todafensis.................. 58

Lamprotornis columbina.................. 59 opaca..................... 59

Laniidaø............................. 34

Lanius cristatus................... $5,9,84$

Laridae............................... 15

leschenaultii, Charadrius................. 13

Pagoa................. 4,8,9,18

leucogaster, Falco...................... 12

leucogastris, Cuncuma.............. 4, $5,6,8,11,12$

leucophila, Hypothymis azurea............ 40

longicauda, Psittacus..................... 21

longicaudus, Conurus.................. 5, 8, 11,21

longipennis, Hemiprocne................ 28

longipennis....... 28

Loriculus galgulus..................... 4, 11,21

lowi, Collocalia..................... 5, 6, 11,26, 27

lyprum, Dicaeum trigonostigmum......... 68

macrocarus, Ceyx tridactylus............. 24, 25

Macropteryx......................... 28

macroura, Kittacincla................... 51

magna, Horizillas........................ 48

magnirostris, Alcippe..................... 47

Horizillas............. 5,7,9,11,47

Oedicnemus................ 15

Orthorhamphus...........4,11,15

magnum, Malacopteron.................... 48

malabarica, Kittacincla.................... 5,51 malabarica.......... 54

malaccensis, Anuropsis malaccensis.... 5, 7,9, 11, 48 Brachypteryx............... 48

malacensis, Anthreptes.................... 62

malacensis........... 61

Afalacopteron........................... 48

magnum.................... 48

melanauchen, Sterna................... 16

melanauchen. $4,7,8,11,16,17$

melanope, Motacilla..................... 61 boarula............ 5, $8,9,61$

melanthe, Dicaeum trigonostigmum........ 68 
metallicus, Lamprocorax.................. $\quad 58$ microlophus, Dissemurus paradiseus........ 5, $6,7,8,9,10,11,59,60$

Anicropodidae. $6,7,8,9,10,11,59,60$

Mticropus sublureatus.................. 5, 11,26

minor, Fregata minor ............... 4,11,12

Lamprocorax..................... 58

Peleenus........................ 12

minuta, Pisobia ....................... 14, 15

Mixornis gularis......................... 4

pilerta....................... 49

everetti.................. 49

nileata................. 49

zophera.... 5, 6, 7, 8, 9, 10, $11,49,50$

modestus, Brachvpus.................... $\quad 46$

Mrotacilla boarula melanope............. 5, 8, 9, 61 gularis..................... 49

melanope................ 61

Motacillidae.......................... 61

Muscadivores aeneus aeneus................ 18 chalyburus............ 19 polius... 4,6, 7, 8, 10,11, 18, 19

Mruscicapa panarensis. zanthony gin................ 3s

Mruscicapldae........................... $\quad 35$ Mtyristicivora bicolor............... 4, $5,6,7,11,18$

Nectariniidae.......................... 61

neoxena, Ifiruldo................... 34

nicobarica, Calcenas................... 4, 11, 17 Columba...................... 17

Hypothymis azurea............ $\quad 39$

onhuonsis, Arenaria interpres........... 4, 7,9,12 Tring:..................... 12

oberholseri, Hypothymis azurea ............ $\quad 39$

ochroptila, Kituacincla malabarica......... b,

$6,7,8,9,10,11,51,53$

oclrropyrrba, Aethopyga siparaja.......... 5, $6,7,8,9,10,11,65,67$

ocyptera, Hemiprocne longipennis.......... 28

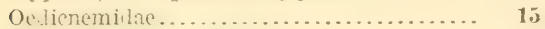

Oedicnemus magnirostris................. 15

olivacea, Iole............................ 44

olivaceus, Pycnonotus simplex........... 43, 45

opaca, $\Lambda$ plonis......................... 59

Calornis ......................... 59

Lamprotornis.................... $\quad 59$

opisthocyanea, IIypothymis azurea........ 1,

$5,6,8,9,11,38,39,40$

origenis, Collocalia........................ 27

Orthorhamphus magnirostris............ 4, 11, 15

Orthotomus atrogularis........ 5, $6, \mathbf{7}, 9, \mathbf{1 1}, \mathbf{5 1 , 5 5}$

Oimotrerem.

Pagoa.

leschenaultii................... 4, 8, 9, 13

palawanensis, Collocalia lowi .............. $2 t$ whiteheadi....... 26,27

palmeri, Hirundo ervthrogastra............ 29

pamirensis, Aegialitis....................... 13

panayensis, Lamprocorax................. 58,59

panayensis........ 57

Muscicapa.................... 58

paradiseus, Dissemurus paradiseus......... $\quad 59$

pelecanoides, Sterna....................... 15

Thalasseus bergil....... $4,7,8,11,15$
Page.

perlonga, Homiprocne longipennis........... 28

philippinensis, Cyornis banyumas......... 35, 26

Picnonotus simplex..................44, 46

pileata, Mixornis....................... 49

$\begin{array}{rr}\text { pileata................... } & 49 \\ \text { Prinia........................... } & 49\end{array}$

Sterna.......................... 17

pileatus, Anous stolidus................ 4, 11, 17

Pisobia minuta.......................... 14, 15

ruficollis..................... 4, 7,9,14

Phoenicophaeus erythrognathus............ 22

plumosus, Pycnonotus.................... 44

plumosus.......... 41

Pluvialis dominica fulva . . .............. 4,9,13

polius, Muscadivores aeneus... 4, 6, 7,8,10,11,18,19

ponera, Hypothymis azurea.............. 40

prasiocara, Gracula javana.... 5, 6, 7,8, 10, 11, 55, 56

prillwitzi, Pycnonotus.................... 47

simplex............ 47

Prinia pileata......................... $\quad 49$

prophata, Hypothymis azurea............ 39

provida, Sterna malanauchen............ 16, 17

Psittacidae............................. 21

Psittacus galgulus....................... 21

longicauda..................... 21

Prcononotidae....................... $\quad 40$

Pycnonotus brunneus................... 44,46

brunneus............ 45,46

zapolius.... $5,6,10,11,45,46$

olivaceus chloeodis........... 44,45

plumosus.................... 44

chiroplethis......... 5 ,

$6,7,10,11,41,43$

plumosus............ $\quad 41$

prillwitzi................... 47

simplex................... 44, 45

halizonus........... 5 ,

$6,9,10,11,43,44,45,46$

olivaceus........... 43,45

prillwitzi............. 47

simplex.............. 43,45

pyrrhothorax, Charadrius.................. 13

Rhamphococcyх...................... 22

richmondi, Hypothymis azurea........... $\quad 40$

robusta, Ceyx rufidorsa..................... 23

ruficollis, Pisolia..................... 4, $7,9,14$

Trynga........................ 14

rufidorsa, Ceyx......................... 23

rufidorsus, Ceyz rufidorsus............ 5,9, 11,28

rustica, Hirundo. . . . . . . . . ............. 30,32, 34

rustica.............. 29, 30,31

sacra, Ardea.......................... $\quad 12$

Demiegretta................. 4,11, 12 Sauronat is ................................

savignii, Hirundo.......................... 29,31

rusticn............... 30,31

Scolopacidiae.......................... 14

sharpei, Ceyx............................ 23

simplex, Picnonotus..................... 44, 46

Pycnonotus..................... 44, 45

simplex.............. 43,45

siparaja, Aethopyga siparaja............... 65

solitaria, Therosi...................... $\quad 26$

solitarius, Ceyx......................... 25 


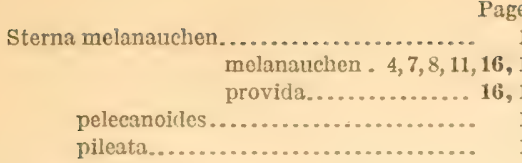

striata, Aplonis......................... 59

strigatus, Lamprocorax payanensis ......... 57,58

Turdus........................ 58

styani, Hypothymis azurea................. 39

suavis, Kittacincla malabarica.............. . 51,54

subfurcutus. ('y prelus.................

Micropis................ $5,11, \mathbf{2 6}$

subfusen, IIirminlo.................... ;1

sumatrensis, $\Lambda$ rtamides sumatrensis........ 34

Sylviidae............................. 54

symmixta, Hypoth rmis azurea ............ 40

tabuensis, Aplonis....................... 59

tahitica, Irirmado...................... 31

Thalasseus............................ 15

bergii ........................ 15

pelecanoides........4, 7,8,11,15

thapsina, Aegithina viridissima... 5, $6,10,11, \mathbf{1 0}, 41$

Therosa............................. 25

argeniata..................... 20

cyanopectus......................

solitaria.

thoa, Iemiprocne longipennis

Timaliidae.

todarensis, Lamprocorax.

Totanus totanus eurhinus.

transitiva, Hirundo rustica.
Page.

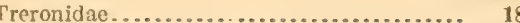

tridactylus, Ceyx..................... 23,24,25

tridactylus ............... 24,25

trigonostigma, Dicaeum................... 67

trigonostigmum, Dicaeum trigonostigmum.. 67

Tringa hypoleucos....................... 15

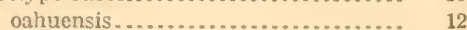

Trynga ruficollis........................... 14

Tupaia.................................. 3

Turdidae..............................

Turdinus............................. 49

Turdus chalybeus..................... 5s

columbinus...................... 59

strigatus......................... 58

tytleri, Hirundo............................. 29, 30

rustica................. 29, 30,31

Hypothymis azurea.................
Urococcyx ............................

erythrognathus............. 5, 6, 11, 22

vernans, Dendrophassa vernans............ 20

virescens, Butorides........................ 1

viridissima, Aegithina.................... 41

viridissima......... 40

vitiensis, Aploni ...................... 59

whiteheadi, Collecalia.................. 26, 27

whitehesdi......... 26,27

Xanthopygia zanthoprgia.............. 5, 6,9,38

zanthopygia, Muscicapa.................. 38

Xanthopygia............ 5, 6, 9, 38

zapolius, Pycnonotus brunneus... 5, 6, 10, 11, $\mathbf{4 5}, 46$

zophera, Mixornis pileata... 5, 6, 7, 8,9, 10, 11, 49, 50 












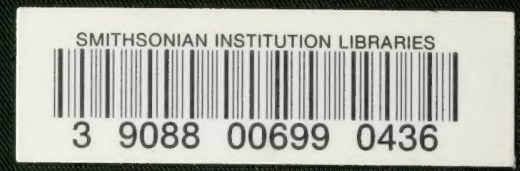

